Florida International University FIU Digital Commons

6-14-2011

\title{
The Impact of Institutional Complexity and Top Management Characteristics on Executive Compensation and Firm Performance
}

Yu-Kai Wang

Florida International University, ywang012@fiu.edu

DOI: $10.25148 /$ etd.FI1 1072512

Follow this and additional works at: https://digitalcommons.fiu.edu/etd

\section{Recommended Citation}

Wang, Yu-Kai, "The Impact of Institutional Complexity and Top Management Characteristics on Executive Compensation and Firm Performance" (2011). FIU Electronic Theses and Dissertations. 427.

https://digitalcommons.fiu.edu/etd/427 


\section{FLORIDA INTERNATIONAL UNIVERSITY \\ Miami, Florida}

\section{THE IMPACT OF INSTITUTIONAL COMPLEXITY AND TOP MANAGEMENT CHARACTERISTICS ON EXECUTIVE COMPENSATION AND FIRM \\ PERFORMANCE}

A dissertation submitted in partial fulfillment of the

requirements for the degree of DOCTOR OF PHILOSOPHY

in

BUSINESS ADMINISTRATION

by

Yu-Kai Wang

2011 


\section{To: Dean Joyce Elam}

\section{College of Business Administration}

This dissertation, written by Yu-Kai Wang, and entitled The Impact of Institutional Complexity and Top Management Characteristics on Executive Compensation and Firm Performance, having been approved in respect to style and intellectual content, is referred to you for judgment.

We have read this dissertation and recommend that it be approved.

\section{Joyce Elam}

Jose de la Torre

William Newburry

Gerry Sanders

Aya Chacar, Major Professor

Date of Defense: June 14, 2011

The dissertation of Yu-Kai Wang is approved.

Dean Joyce Elam

College of Business Administration

Interim Dean Kevin O'Shea

University Graduate School

Florida International University, 2011 


\section{DEDICATION}

I dedicate this dissertation to my parents, Chieh-Ming Wang and Su-Tseng Su Wang, and my wife, Victoria Shih. Without their understanding, support, and encouragement, the completion of this work would not have been possible. 


\section{ACKNOWLEDGMENTS}

I wish to thank my committee for their support, patience, encouragement, and professionalism. I am grateful to Dr. Joyce Elam for her guidance on how to balance between academic theories and their practical applications. I am also indebted to Dr. Jose de la Torre and Dr. William Newburry for their critical and insightful suggestions. Also I have benefited greatly from Dr. Gerry Sanders's deep knowledge on corporate governance and leadership. Especially, I would like to thank my major professor, Dr. Aya

Chacar, whom I have always looked to for guidance and inspiration. Had she not spent so much of her time assisting me conquer all kinds of difficulties encountered in my dissertation, I would not have been where I am.

The completion of the dissertation is the final stage of my doctoral study. During my doctoral study, I received a lot of support from the entire Department of Management and International Business. Particularly, I would like express my thankfulness to Dr. Chris (Changwha) Chung for sharing his experience on data collection and analysis with me even after he has left the department, as well as to Dr. Galen Kroeck, Chair of the department, for providing me with an excellent learning environment and necessary support. I also would like to express my gratitude to Sokol Celo and Yannick Thams, both of whom are my colleagues, for their comments and suggestions to my dissertation. Finally, I would like to give thanks to my friends and colleagues, including Armando Borda, Abdul Beydoun, Abrahim Soleimani, Jiangyun Wan, Kun Yang, Wei He, and Watcharaphong Leartsuraat, for their great support and company during my doctoral study. 
ABSTRACT OF THE DISSERTATION

THE IMPACT OF INSTITUTIONAL COMPLEXITY AND TOP MANAGEMENT

CHARACTERISTICS ON EXECUTIVE COMPENSATION AND FIRM

PERFORMANCE

by

Yu-Kai Wang

Florida International University, 2011

Miami, Florida

Professor Aya Chacar, Major Professor

While most studies take a dyadic view when examining the environmental difference between the home country of a multinational enterprise (MNE) and a particular foreign country, they ignore that an MNE is managing a network of subsidiaries embedded in diverse environments. Additionally, neither the impacts of global environments on top executives nor the effects of top executives' capabilities to handle institutional complexity are fully explored. Thus, using a three-essay format, this dissertation tried to fill these gaps by addressing the effects of institutional complexity and top management characteristics on top executive compensation and firm performance.

Essay 1 investigated the impact of an MNE's institutional complexity, or the diversity of national institutions facing an MNE's network of subsidiaries, on the top management team (TMT) compensation. This essay proposed that greater political and cultural complexity leads to not only greater TMT total compensation but also to a greater portion of TMT compensation linked with long-term performance. The arguments 
are supported in this essay by using an unbalanced panel dataset including 296 U.S. firms with 1,340 observations.

Essay 2 explored TMT social capital and its moderating role on value creation and appropriation by the chief executive officer (CEO). Using a sample with 548 U.S. firms and 2,010 observations, it found that greater TMT social capital does facilitate the effects of CEO intellectual capital and social capital on firm growth. Finally, essay 3 examined the performance implications for the fit between managerial information-processing capabilities and institutional complexity. It proposed that institutional complexity is associated with the needs of information-processing. On the other hand, smaller TMT turnover and larger TMT size reflect larger managerial information-processing capabilities. Consequently, superior performance is achieved by the match among institutional complexity, TMT turnover, and TMT size. All hypotheses in essay 3 are supported in a sample of 301 U.S. firms and 1,404 observations.

To conclude, this dissertation advances and extends our knowledge on the roles of institutional environments and top executives on firm performance and top executive compensation. 
TABLE OF CONTENTS

CHAPTER PAGE

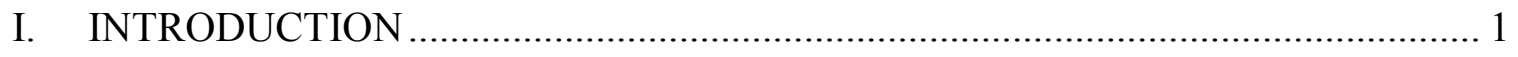

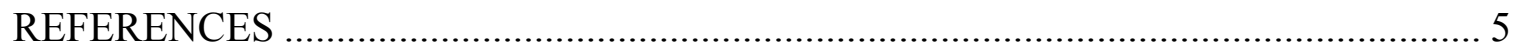

II. MULTINATIONAL ENTERPRISE'S INSTITUTIONAL COMPLEXITY AND

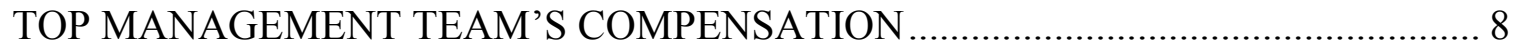

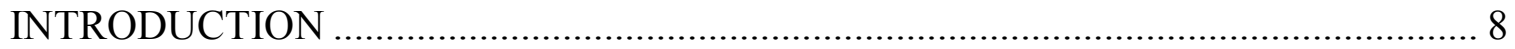

INFORMATION-PROCESSING REQUIREMENTS AND EXECUTIVE

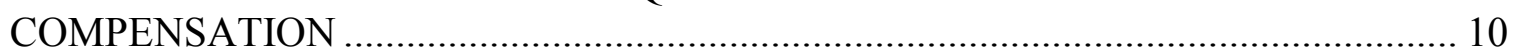

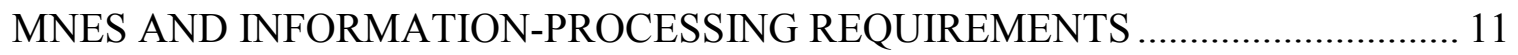

MNE INSTITUTIONAL COMPLEXITY AND TMT COMPENSATION ................... 14

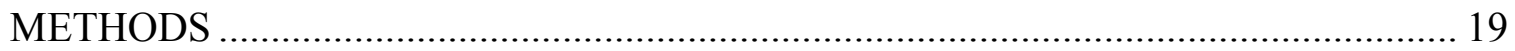

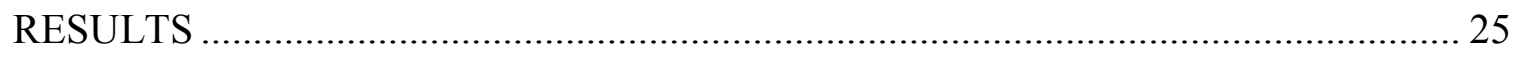

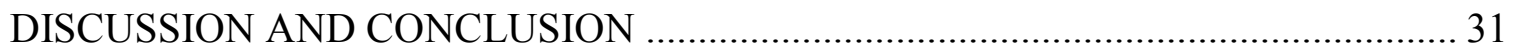

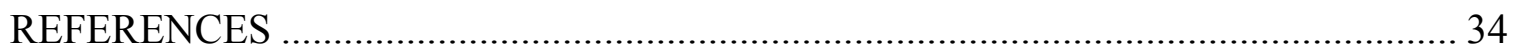

III. TOP MANAGEMENT TEAM'S SOCIAL CAPITAL AND ITS MODERATING ROLE ON VALUE CREATION AND APPROPRIATION BY THE CEOS ................ 40

INTRODUCTION .......................................................................................... 40

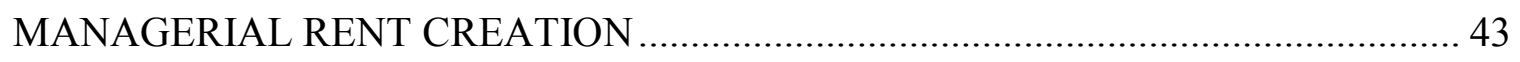

MANAGERIAL RENT APPROPRIATION ......................................................... 51

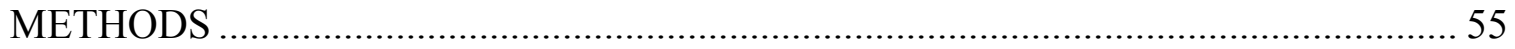

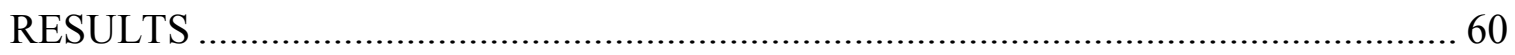

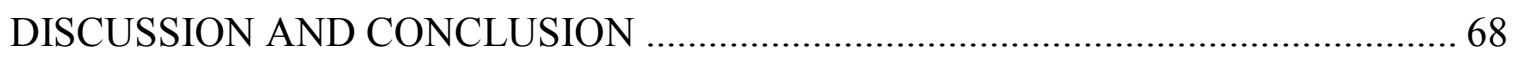

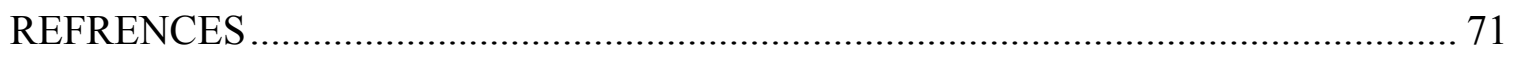

IV. THE IMPACT OF A FIRM'S INSTITUTIONAL COMPLEXITY, TOP MANAGEMENT TEAM TURNOVER, AND TOP MANAGEMENT TEAM SIZE ON FIRM PERFORMANCE: A STRATEGIC CONTINGENCY PERSPECTIVE....... 75

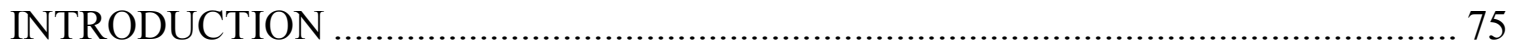

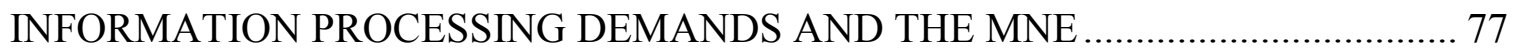

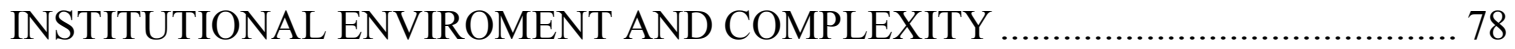

INSTITUTIONAL COMPLEXITY AND FIRM PERFORMANCE …........................ 79

TMT, INSTITUTIONAL COMPLEXITY, AND FIRM PERFORMANCE .................. 83

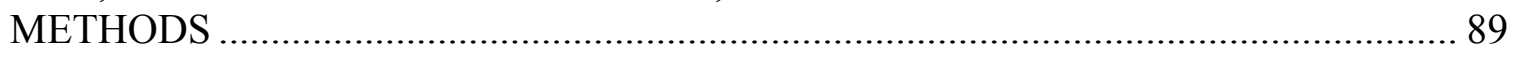

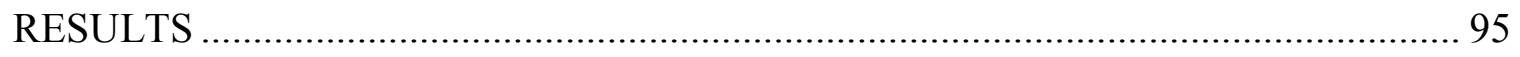

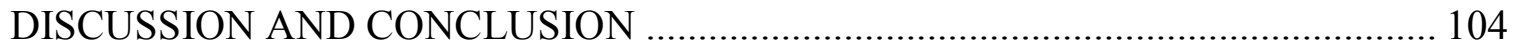

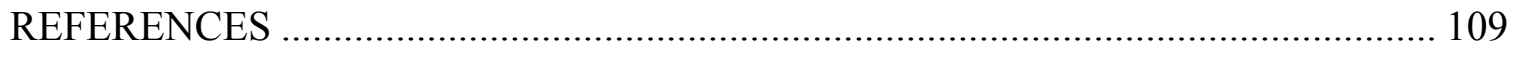

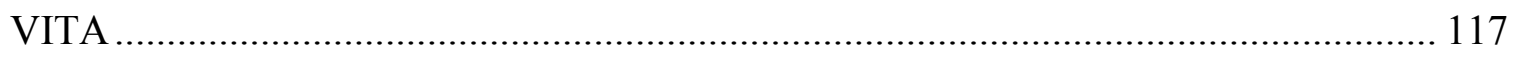




\section{LIST OF TABLES}

TABLE

PAGE

Table 2.1 Summary of Variable Definition and Data Sources for Essay $1 \ldots \ldots \ldots \ldots \ldots \ldots . . .21$

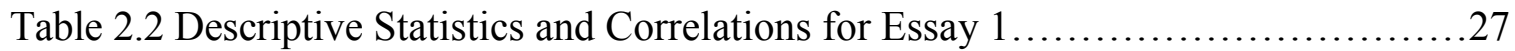

Table 2.3 Results of Fixed-effects Linear Regression Analyses for TMT Total

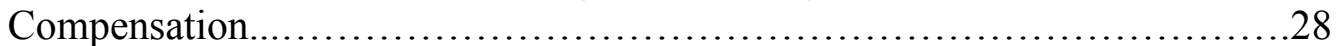

Table 2.4 Results of fixed-effects Linear Regression Analyses for TMT Long-term Compensation Ratio.................................................30

Table 3.1 Summary of Variable Definition and Data Sources for Essay 2...................56

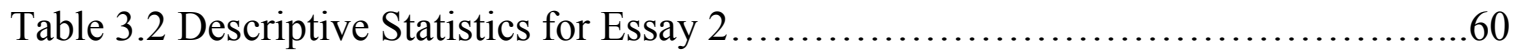

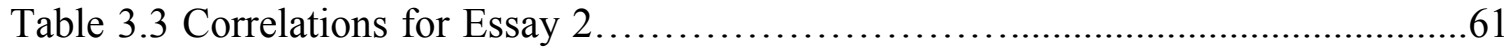

Table 3.4 Results of Fixed-effects Linear Regression Analyses for Sales Growth........62

Table 3.5 Results of Fixed-effects Linear Regression Analyses for CEO Total Compensation..................................................67

Table 4.1 Variable Definition and Data Sources for Essay $3 \ldots \ldots \ldots \ldots \ldots \ldots \ldots \ldots \ldots$

Table 4.2 Descriptive Statistics and Correlations for Essay $3 \ldots \ldots \ldots \ldots \ldots \ldots \ldots \ldots \ldots \ldots . . .68$

Table 4.3 Descriptive Statistics and Correlations for Essay 3.......................99

Table 4.4 Results of Fixed-effects Linear Regression Analyses for ROA...............100

Table 4.5 Results of Fixed-effects Linear Regression Analyses for ROS...............105 


\section{LIST OF FIGURES}

FIGURE

PAGE

Figure 3.1 Relationship between Sales Growth and CEO Intellectual Capital at Different

Levels of TMT Social Capital.........................................65

Figure 3.2 Relationship between Sales Growth and CEO Social Capital at Different Levels of TMT Social Capital.......................................65

Figure 4.1 Relationship between Firm Performance and Political Complexity at Different TMT Turnover Levels..........................................102

Figure 4.2 Relationship between Firm Performance and Cultural Complexity at Different TMT Turnover Levels................................................102

Figure 4.3 Relationship between Firm Performance and Political Complexity at Different TMT Size Levels..............................................103

Figure 4.4 Relationship between Firm Performance and Cultural Complexity at Different TMT Size Levels................................................103 


\section{INTRODUCTION}

This dissertation examines the effects of multinational enterprises' (MNEs) institutional complexity and top management characteristics on firm performance and executive compensation. In the field of strategic management, environments and top executives are two important antecedents of firm performance and executive compensation (e.g., Andrews, 1971; Castanias \& Helfat, 1991 \& 2001; Henderson \& Fredrickson, 1996). In the context of international business, while most studies take a dyadic view when examining the environmental difference between the home country of an MNE and a particular foreign country, they ignore that an MNE is managing a network of subsidiaries in which foreign subsidiaries are embedded in diverse environments. Additionally, neither the impacts of global environments on top executives nor the effects of top executives on MNEs' capabilities to handle international environmental complexity and performance are fully explored. Consequently, this dissertation tries to fill these gaps by examining the effects of institutional complexity and top management characteristics on top executive compensation and firm performance in three essays.

Essay 1 explored the impact of MNEs' institutional complexity on top executive compensation. While much research has examined the antecedents of executive compensation (see Devers, Cannella, Reilly, \& Yoder, 2007 for a comprehensive review), the impact of MNEs' context has been under-explored. In addition, past research has emphasized the impact of managerial capabilities on firm performance (e.g., Carpenter, Sanders, \& Gregersen, 2001; Geletkanycz \& Hambrick, 1997). However, with few 
exceptions (e.g., Carpenter et al., 2001), most studies pay little attention to this impact in the context of MNEs.

Prior studies proposed that environmental complexity augments the information processing requirements of top executives, and, hence, will ultimately lead to an increase in top executive compensation (e.g., Henderson \& Fredrickson, 1996; Sanders \& Carpenter, 1998). Empirical results also support this suggestion, demonstrating that increased internal operational complexity leads to increased top executive compensation (e.g., Henderson \& Fredrickson, 1996) and that increased internationalization has the same impact on top executive compensation (Sanders \& Carpenter, 1998).

Following this line of research, essay 1 expands the examination of environmental complexity to include international environmental complexity. MNEs operating in multiple countries face not only internal complexity but also external environmental complexity (e.g., Verbeke, Li, \& Goerzen, 2009). National institutional environments restrict and constrain resource redeployment within firms and ultimately the choice of firm strategy and performance (e.g., Chacar \& Vissa, 2005; Chacar, Newburry, \& Vissa, 2010). These national constraints (North, 1990) make it more difficult for companies to transfer current competencies and make these existed competencies less relevant (Kostova, 1999).

Ultimately, operating in diverse national institutional environments augments the complexity of the managerial task, over and beyond what an increased level of internationalization may cause (Verbeke et al., 2009). However, the effects of external environmental complexity, especially MNEs' institutional complexity, or the diversity of national institutions, facing MNEs' network of subsidiaries, have been ignored. Thus, the 
first essay examines the effect of MNEs' institutional complexity on top executive compensation.

Essay 2 examined top management team (TMT) social capital and its moderating role on value creation and appropriation by the CEO. Prior research has documented the effects of executives' intellectual and social capital on the executive compensation (e.g., Carpenter et al., 2001; Carpenter \& Wade, 2002; Combs \& Skill, 2003) and performance (e.g., Carpenter et al., 2001; Geletkanycz \& Hambrick, 1997). However, the relationships between the interactions of managerial capabilities between CEOs and their TMTs have been neglected.

Thus, essay 2 argued that, on the one hand, the resource-based view of a firm (Barney, 1991; Wernerfelt, 1984) and the resource complementarity perspective (Amit \& Schoemaker, 1993) contend that TMT social capital complement CEO intellectual and social capital, and thus lead to greater performance. On the other hand, drawing from the rent appropriation theory (Chacar \& Coff, 2000; Coff, 1999) and other bargaining power theories (Pfeffer \& Salancik, 1978; Porter, 1980), CEOs' bargaining power on their compensation will be weakened. This is because the exercise of CEO intellectual/social capital is dependent on the extent of TMT social capital.

Essay 3 investigated the impact of MNEs' institutional complexity, TMT turnover, and TMT size on firm performance, taking a strategic contingency perspective. While the relationship between multinationality and performance has been frequently explored, the results from this research are inconclusive (e.g., Contractor, Kundu, \& Hsu, 2003; Geringer, Beamish, \& daCosta, 1989; Lu \& Beamish, 2004; Tallman \& Li, 1996). Synthesizing past research, Verbeke et al. (2009) proposed that these studies have been 
criticized for ignoring the critical elements faced by MNEs. Most notably, prior studies that investigate the relationship between international diversification and MNE performance pay little attention to (1) the differentiated international environments faced by MNEs (Verbeke et al., 2009), as well as (2) the managerial abilities of MNEs (Geringer et al., 1989). To fill these gaps, this essay examined the impacts of institutional complexity, TMT turnover, and TMT size on MNE performance taking a strategic contingency perspective. Essay 3 argued that institutional complexity is associated with information-processing needs. On the other hand, larger managerial informationprocessing capabilities are achieved by smaller TMT turnover and larger TMT size. Consequently, the fits among institutional complexity, TMT turnover, and TMT size lead to superior firm performance.

This dissertation contributes to current research as follows. First, this dissertation demonstrates that national institutions are key drivers not only of firm performance and strategic actions (e.g Chacar \& Vissa, 2005; Chacar et al, 2010; Henisz, 2000) but also of top executive compensation. Second, this dissertation will contribute to the theory on top executives by showing that TMT social capital can complement CEO intellectual/social capital (Amit \& Schoemaker, 1993; Krishnan, Miller, \& Judge, 1997). Finally, this dissertation applies the strategic contingency perspective to explore the match between information-processing needs and information-processing capabilities in the context of MNEs and once again to show the importance of tailoring internal components with external environments (Prescott, 1986; Vissa \& Chacar, 2009). 


\section{REFERENCES}

Amit, R. \& Schoemaker, P. J. H. 1993. Strategic assets and organizational rent. Strategic management journal, 14(1): 33-46.

Andrews, K. R. 1971. The Concept of Corporate Strategy. Homewood, IL: Irwin.

Barney, J. B. 1991. Firm resources and sustained competitive advantage. Journal of management, 17(1): 99-120.

Carpenter, M. A., Sanders, G., \& Gregersen, H. B. 2001. Bundling human capital with organizational context: The impact of international assignment experience on multinational firm performance and CEO pay. The Academy of Management Journal, 44(3): 493-511.

Carpenter, M. A. \& Wade, J. B. 2002. Microlevel opportunity structures as determinants of non-CEO executive pay. The Academy of Management Journal, 45(6): 10851103 .

Castanias, R. P. \& Helfat, C. E. 1991. Managerial resources and rents. Journal of Management, 17(1): 155-171.

Castanias, R. P. \& Helfat, C. E. 2001. The managerial rents model: Theory and empirical analysis. Journal of Management, 27(6): 661-678.

Chacar, A. S. \& Coff, R. W. 2000. Deconstructing a knowledge-based advantage: rent generation, rent appropriation and performance in investment banking. In D. Hesuskel \& R. Nixon (Eds.), Winning Strategies in a Deconstructing World. New York: John Wiley.

Chacar, A. \& Vissa, B. 2005. Are emerging economies less efficient? Performance persistence and the impact of business group affiliation. Strategic Management Journal, 26(10): 933-946.

Chacar, A. S., Newburry, W., \& Vissa, B. 2010. Bringing institutions into performance persistence research: Exploring the impact of the product, financial and labor market institutions. Journal of International Business Studies, 41(7): 1119-1140.

Coff, R. W. 1999. When competitive advantage doesn't lead to performance: The resource-based view and stakeholder bargaining power. Organization Science, 10(2): 119-133.

Combs, J. G. \& Skill, M. S. 2003. Managerialist and human capital explanations for key executive pay premiums: A contingency perspective. Academy of Management Journal, 46(1): 63-73. 
Contractor, F. J., Kundu, S. K., \& Hsu, C. C. 2003. A three-Stage theory of international expansion: The link between multinationality and performance in the service sector. Journal of international business studies, 34(1): 5-19.

Devers, C. E., Cannella, A. A., Reilly, G. P., \& Yoder, M. E. 2007. Executive compensation: A multidisciplinary review of recent developments. Journal of Management, 33(6): 1016-1072.

Geletkanycz, M. A. \& Hambrick, D. C. 1997. The external ties of top executives: Implications for strategic choice and performance. Administrative Science Quarterly, 42(4): 654-681.

Geringer, J. M., Beamish, P. W., \& DaCosta, R. C. 1989. Diversification strategy and internationalization: Implications for MNE performance. Strategic Management Journal, 24(13): 109-119.

Henderson, A. D. \& Fredrickson, J. W. 1996. Information-processing demands as a determinant of CEO compensation. The Academy of Management Journal, 39(3): 575-606.

Henisz, W. J. 2000. The institutional environment for multinational investment. Journal of Law, Economics, and Organization, 16(2): 334-364.

Kostova, T. 1999. Transnational transfer of strategic organizational practices: A contextual perspective. Academy of Management Review, 24(2): 308-324.

Krishnan, H. A., Miller, A., \& Judge, W. Q. 1997. Diversification and top management team complementarity: is performance improved by merging similar or dissimilar teams? Strategic Management Journal, 18(5): 361-374.

Lu, J. W. \& Beamish, P. W. 2004. International diversification and firm performance: The S-curve hypothesis. The Academy of Management Journal, 47(4): 598-609.

North, D. C. 1990. Institutions, institutional change and economic performance. Cambridge: Cambridge university press.

Pfeffer, J. \& Salancik, G. R. 1978. The external control of organizations: A resource dependence perspective. New York: Harper \& Row Publishers.

Porter, M. E. 1980. Competitive strategy: techniques for analyzing industries and competitors. New York: Free Press.

Prescott, J. E. 1986. Environments as moderators of the relationship between strategy and performance. The Academy of Management Journal, 29(2): 329-346. 
Sanders, W. M. G. \& Carpenter, M. A. 1998. Internationalization and firm governance: The roles of CEO compensation, top team composition, and board structure. The Academy of Management Journal, 41(2): 158-178.

Tallman, S. \& Li, J. 1996. Effects of international diversity and product diversity on the performance of multinational firms. Academy of Management Journal, 39(1): 179196.

Verbeke, A., Li, L., \& Goerzen, A. 2009. Toward more effective research on the multinationality-performance relationship. Management International Review, 49(2): 149-161.

Vissa, B. \& Chacar, A. S. 2009. Leveraging ties: the contingent value of entrepreneurial teams' external advice networks on Indian software venture performance. Strategic Management Journal, 30(11): 1179-1191.

Wernerfelt, B. 1984. A resource-based view of the firm. Strategic management journal, 5(2): 171-180. 


\section{MULTINATIONAL ENTERPRISE'S INSTITUTIONAL COMPLEXITY AND TOP MANAGEMENT TEAM'S COMPENSATION INTRODUCTION}

International business research has been increasingly focused on the importance of national institutions and their impact on strategic decision making and firm performance (e.g., Chacar \& Vissa, 2005; Chacar, Newburry, \& Vissa, 2010; Delio \& Henisz, 2003; Henisz, 2000; Kostova, 1999; Kostova \& Roth, 2002; Mudambi \& Navarra, 2002). In addition, as firms internationalize, executives have to deal with multiple national environments, increasing the complexity of the managerial task (e.g., Birkinshaw, Toulan, \& Arnold, 2001; Ghoshal, Korine, \& Szulanski, 1994; Sanders \& Carpenter, 1998). Consequently, one would expect the compensation of top executives to increase with the increased level of international institutional complexity that they need to manage. Surprisingly, we know little about this issue, although past research has documented that managerial information-processing demand is positively associated with top executive compensation (e.g. Henderson \& Fredrickson, 1996; Sanders \& Carpenter, 1998).

In this study, we argue that international institutional complexity, or managing subsidiaries embedded in heterogeneous national institutional environments, is an important consideration in executive compensation decisions. In line with past research (Kostova, 1999), we propose that when faced with similar national institutions, executives can more readily deploy competencies already developed, but when disparities between home and host country institutions are larger, greater information processing will be needed, which in turn should lead to greater compensation (e.g. Daft \& Lengel, 1986; Thompson, 1967; Tushman \& Nadler, 1978). We hence propose that firms with 
greater international institutional complexity will need to compensate to a greater degree their executives. Built on past literature, we propose that both the formal and the informal institutional environments (North, 1990) are the key elements of institutional complexity. Among the elements of formal and informal institutions, political and cultural institutions are most salient and likely to influence executive compensation respectively (Henisz, 2000; Kogut \& Singh, 1988). Accordingly, top executives' compensation will need to reflect the higher information-processing demands associated with disparities among the host countries of a multinational enterprise (MNE) in terms of political institutions and culture (Tushman \& Nadler, 1978). Our empirical tests, based on compensation of top executives in 296 U.S. firms with 1,340 observations from 2002 to 2009 indeed show that greater dispersion in national institutional environments facing the MNE subsidiary network leads to greater compensation of MNE executives.

In the following sections, we first discuss theoretically the relationship between MNE's institutional complexity and executive compensation, based on the informationprocessing perspective and dispersion of national institutions within an MNE network. We then propose that such MNE's institutional complexity will lead to increased compensation of top management team (TMT) compensation and its long-term proportion. Next, we describe our empirical methodology and present the main results. Finally, we discuss the contributions of this study and make suggestions for future research. 


\section{INFORMATION-PROCESSING REQUIREMENTS AND EXECUTIVE COMPENSATION}

Information processing plays a critical role in executives' duties. Top executives must scan and monitor external environments, examine internal resources, collect data and analyze it, and then make strategic choices (Andrews, 1971). In all of these tasks, executives must process large amounts of information before making the decisions (Mintzberg, 1973; Ungson, Braunstein, \& Hall, 1981). Since information processing constitutes a major part of executives' duties, their compensation should be related to information-processing requirements in their firm (e.g., Henderson \& Fredrickson, 1996).

Indeed, prior research has proposed that the greater the information-processing requirements on top executives, the greater their compensation will be. For example, Henderson and Fredrickson (1996) proposed that managing greater amounts of R\&D and capital investment activities makes organizations more complex. Greater investments in R\&D activities are associated with developing more advanced technologies or greater scales of R\&D projects, which in turn increase technological uncertainty. Ultimately, larger scales of R\&D projects may require a greater diversity of inputs and a higher extent of coordination. All of these request a greater level of information-processing requirements and ultimately top executive compensation (Henderson \& Fredrickson, 1996). There is also evidence that increased scope, be it horizontal, vertical, or international also affects compensation. For example, Henderson and Fredrickson (1996) proposed that when a firm becomes more diversified, top executives are required to process a greater amount of information (Chandler, 1962; Prahalad \& Bettis, 1986), leading to greater top executive compensation. This is driven by the need for executives to handle more non-routine 
strategic decisions in a firm with a broader business unit portfolio (Thompson, 1967). These non-routine strategic decisions may be associated with not only the related diversification that increases the need of interdependence among subunits (e.g. Jones \& Hill, 1988) but also the unrelated diversification that enhances the challenge of allocating internal capital efficiently (Jones \& Hill, 1988). Henderson and Fredrickson (1996) also proposed that vertically integrated firms have greater capital investment activities and require more coordination of upstream and downstream activities. Thus these firms will necessitate greater information-processing and ultimately greater compensation levels.

Focusing on international scope, Sanders and Carpenter (1998) proposed that a greater international diversification means that the headquarters of an MNE need to manage a larger portfolio of foreign subsidiaries. In other words, the dyadic linkages between the MNE and its subsidiaries increase. For the top executives at the headquarters of the MNE, this means processing greater extents of information (Contractor, Kundu, \& Hsu, 2003; Geringer, Beamish, \& daCosta, 1989). In addition to the increase of dyadic linkages, a greater international diversification also increases the demands for coordinating or managing the interactions among subsidiaries (e.g., Ghoshal \& Bartlett, 1990). In fact, as Sanders and Carpenter's (1998) study demonstrated, the extent of international diversification is positively related to $\mathrm{CEO}$ total compensation.

\section{MNES AND INFORMATION-PROCESSING REQUIREMENTS}

MNEs are often described as highly complex organizations (Ghoshal \& Nohria, 1989). This complexity, in turn, creates high information-processing requirements on executives managing these MNEs (Egelhoff, 1991). In that vein, a large stream of literature on MNEs has argued that large internal information-processing requirements play an 
important role in determining the choice of MNE structure. For example, portraying an MNE as an information-processing system, Egelhoff (1982) proposed that MNE structure is determined by its strategy. The underlying logic of the relationship is that the chosen strategy determines the information-processing requirements between the MNE and its foreign subsidiaries or among subsidiaries. From this internal information-processing viewpoint, Wolf and Egelhoff (2002), focusing on internal information-processing requirements, further posited that foreign $\mathrm{R} \& \mathrm{D}$ activities are positively associated with an MNE's structure based on a geographic region or worldwide function division.

Information-processing requirements, however, not only originate from the internal networking of an MNE and its chosen strategy, but also are affected by external institutional environments. Indeed, another strand of the international business literature on foreign direct investments, international diversification, and entry has emphasized the critical role of external environmental complexity. For example, Hymer (1976) highlighted the impact of the environmental differences between home and host countries on the success of MNEs. He argued that MNEs that enter into and operate within foreign countries face costs of doing business abroad, because these foreign countries have different environments such as governmental regulations, social norms, and customer tastes. Thus, Hymer argued that in order to enter and operate in foreign countries, MNEs need to possess ownership advantages, such as superior technological capabilities, to overcome these disadvantages, compared with indigenous firms in the host countries. Zaheer (1995) expanded on the work of Hymer's, terming the costs of doing business abroad the "liability of foreignness". 
Similarly, in the theory of internationalization process (Johnanson \& Vahlne, 1977 \& 1990) external environments are perceived as complex, albeit varyingly, so international environmental complexity is viewed as adding to the information-processing requirements of an MNE. The theory of internationalization process considers international environments as a critical foundation. This theory argues that in the early stages, an MNE may enter foreign markets that are closer to home or less complex to understand. These are the countries with the smallest psychic distance from the home country and in which environments are easier to learn and understand. As MNEs learn and accumulate international experience, MNEs may enter foreign markets with larger psychic distance. Hence, the process of a firm's internationalization would be incremental.

Among the international environmental factors, the effects of national institutions on the operations of MNEs have been emphasized (e.g. Kostova \& Roth, 2002). Because these national institutions differ among countries (Kostova, 1999), institutional distance between home and host countries matters for MNEs. For instance, drawing on institutional theory, Kostova (1999) proposed that the transfer of organizational practices from an MNE to its subsidiaries is affected by differences in regulatory, cognitive, and normative components of national institutions. Kostova and Roth (2002) also found that subsidiaries' adoptions of their practices are determined by national institutions in the host countries. National institutions affect not only the internal operations of subsidiaries of MNEs but also their relationships with external environments. For example, Kostova and Zaheer (1999) demonstrated how MNEs' legitimacy in host countries is hampered by institutional complexities. 


\section{MNE INSTITUTIONAL COMPLEXITY AND TMT COMPENSATION}

While the executive compensation literature has focused primarily on internal environmental complexity (Henderson \& Fredrickson, 1996; Sanders \& Carpenter, 1998), we emphasize in this study the importance of external environmental complexity, which is driven by managing subsidiaries in various national institutions, or MNE's institutional complexity. Firm behavior and performance are shaped and constrained by both formal and informal national institutions (North, 1990; Kostova \& Roth, 2002). Thus, apart from industry structural attributes and firm-specific characteristics, firm strategies and hence information-processing requirements likely also depend on national institutional factors (e.g., Chacar \& Vissa, 2005).

Institutions are humanly developed constraints that shape human interaction and are akin to the 'rules of the game' (North, 1990). An economy's institutional context is a combination of formal rules, informal constraints, and their enforcement characteristics. With institutional change usually being gradual and path dependent, institutional contexts vary significantly across countries, and even neighboring countries or countries of otherwise similar characteristics can have wildly different national institutions (North, 1990; Kostova, 1999). Institutions impact firm strategic choices, operations and/or governance structures (e.g., Leff, 1978; Murtha \& Lenway, 1994) and industry structure (Caves, 1986). Ultimately, different institutions require different strategic responses from firms (Oliver, 1991) and hence greater information processing on the part of executives managing MNEs. In that vein, for instance, Delios and Henisz (2003) demonstrated that experience in dealing with political hazards decreases the sensitivity of firms towards such hazards when making entry decisions. 
Overall, the previous evidence suggests that national institutions impact firm strategic choices, operations and/or governance structures. The more different national institutions in host countries from those in the home country, the more complex it is to operate an MNE and design strategies for its success. In turn, this impacts informationprocessing requirements and ultimately top executive compensation. We hence propose in this study that MNE's institutional complexity derived from managing subsidiaries in diverse national institutions is positively associated with TMT total compensation and the proportion of TMT long-term compensation. In the proposed model, TMT total compensation and the proportion of TMT long-term compensation are driven by two key components of MNE's institutional complexity: political and cultural. Political and cultural institutions are employed to represent national institutions, because these two dimensions have been well documented for their impacts on MNEs strategic making (Henisz, 2000; Meyer, Mudambi, \& Narula, 2011; Schwens, Eiche, Kabst, 2011).

\section{MNE's Political Complexity and TMT Total Compensation}

When MNEs conduct economic activities in foreign countries, they cannot escape the constraints of political environments in host countries (Boddewyn, 1988). Based on the transaction cost arguments (Coase, 1937; Williamson, 1975), political instability can be a proxy for external uncertainty, and thus affect the decision of the choice of entry mode (e.g. Anderson \& Gatignon, 1986; Contractor \& Kundu, 1998). In addition, the entry mode is also determined by political distance between home and host countries (e.g. Erramilli, 1991). This line of research argues that resource commitment in the host countries is affected by local political factors. Thus, top executives of MNEs are required to assess political risk in host countries (Simon, 1984). 
While MNEs can develop skills and routines in dealing with a particular political environment, such as choosing a joint venture rather than a wholly owned subsidiary or engaging in political actions, these skills are highly idiosyncratic and hard to transfer to other countries which are very different in terms of their political profile. Thus, this study expects that managing diverse political distances from their home countries increases information-processing requirements for TMT. The higher extents of informationprocessing requirements lead to a higher extent of TMT total compensation level (Henderson \& Fredrickson, 1996; Sanders \& Carpenter, 1998). Therefore, this study argues:

Hypothesis 1: The greater extent of a firm's political complexity that the TMT of the firm faces, the greater the TMT total compensation.

\section{MNE's Cultural Complexity and TMT Total Compensation}

National culture is concerned with societal value systems of a country (Hofstede, 1984; House, 2004). MNEs operating in multiple countries face various societal values. As a consequence, cultural distances between home and host countries become an issue, influencing strategic decisions and performance of MNEs. For example, at the team level, Von Glinow, Shapiro, and Brett (2004) emphasized that managing emotional conflict is an important issue in multicultural teams.

Differences in national cultures result in different organizational and administrative practices (Kogut \& Singh, 1988), which make the transfer of those practices and the associated acculturation more challenging. From an organizational learning perspective, when expanding to regions close to their knowledge base of foreign cultures, companies improve and refine their existing knowledge (Barkema \& Drogendijk, 2007) leading to 
semi-automatic reproduction of their existing routines (Zollo \& Winter, 2002; Ahuja \& Lampert, 2001), and to the application of existing concepts as well as objects and the linkages between them, rather than to the development of new ones (Cohen \& Levinthal, 1990). In fact, greater cultural distances within the MNE have been linked to lower performance (e.g., Gomez-Mejia \& Palich, 1997).

Since greater cultural distances may lead to poor understanding of host countries, top executives managing subsidiaries located in greater cultural distance areas from their home countries are unable to transfer established routines and may suffer from a greater extent of uncertainty (Shane, Venkataraman, \& Macmillan, 1995). This higher uncertainty demands greater information processing (Tushman \& Nadler, 1978).

We expect that a variety of these cultural distances from their home countries increases information-processing demands for TMTs, because it requires TMTs to manage different cultural environments simultaneously and thus adds to task complexity for TMTs (Tushman \& Nadler, 1978). In other words, although the accumulation of knowledge or path dependence may function (Nelson \& Winter, 1982) and reduce uncertainty, it may not apply to decision making under different cultural contexts. In this case, strategic decisions made for a subsidiary may not apply to other subsidiaries, so higher extents of non-routine decision-making demand a greater amount of information-processing. Since greater cultural distance may lead to greater information-processing demands and thus to greater TMT compensation, the focus of this study is the effects of cultural complexity deriving from managing subsidiaries in diverse cultural environments. Therefore:

Hypothesis 2: The greater extent of a firm's cultural complexity that the TMT of the firm faces, the greater the TMT total compensation. 


\section{MNE's Institutional Complexity and the proportion of TMT long-term compensation}

MNE's institutional complexity not only demands a greater extent of informationprocessing needs for top executives but also creates difficulties for the boards of directors to effectively exercise their monitoring function (Sanders \& Carpenter, 1998). Since the interests of TMT are not always aligned with those of shareholders, top executives may prioritize their personal interests (Jensen \& Meckling, 1976; Eisenhardt, 1989). Particularly, when firms face greater institutional complexity, information asymmetries between top executives and their boards of directors may be greater. Consequently, these top executives may have more room to seek their personal interests rather than maximizing the wealth of shareholders and their boards may face more challenges on limiting these top executive self-interest seeking behaviors (Mace, 1971).

In addition to the monitoring role of boards of directors, the executive incentive alignment mechanism has been widely proposed to solve the issues of divergent goals between top executives and their shareholders (Jensen \& Murphy, 1990; Zajac \& Westphal, 1994). While there are various ways to compensate top executives, they can be categorized as two types: short-term, such as cash, and long-term contingent compensation. The longterm compensation plays the role of a remedy to direct the interests of top executives toward those of shareholders, because the rewards of top executives will rely on the increase of shareholders' wealth. Therefore, prior research has documented that long-term pay mix of top executives affects the strategic choices of top executives (e.g., Datta, Musteen, \& Herrmann, 2009). 
Since top executive incentive alignment and board monitoring are two critical mechanisms to assure that the strategic behaviors of top executives are for the benefits of their shareholders, they can substitute each other (Zajac \& Westphal, 1994). In other words, in the situation that the board's monitoring cannot function effectively due to institutional complex environments, a greater proportion of long-term compensation should be used to direct strategic behaviors of top executives towards interests of shareholders. As such, one would expect that not only political complexity but also cultural complexity are associated with a greater proportion of TMT long-term compensation. Thus, this study proposes:

Hypothesis 3: The greater extent of a firm's political complexity that a TMT faces, the greater the proportion of TMT long-term compensation.

Hypothesis 4: The greater extent of a firm's cultural complexity that a TMT faces, the greater the proportion of TMT long-term compensation.

\section{METHODS}

The data of our sample are derived from multiple archival data sources from 2002 to 2009. We lagged the data of the independent and control variables by one year in order to avoid the reverse causality issue. Therefore, our data on independent and control variables are from 2001 to 2008 . We obtained data from the following sources: (a) the TMT compensation data were obtained from the Compustat ExecuComp database; (b) the subsidiaries information were from the Directory of Corporate Affiliations (DCA) database; (c) the board characteristic data were from the Corporate Library database; (d) industry- and firm-level financial data were drawn from the Compustat database; and (e) the sources of institutional complexity data were acquired from Henisz's Political 
Constraint Index (POLCON) dataset for political institutions as well as Global Project for national cultural institutions.

The final sample contained information on 296 U.S. based MNEs with 1,340 observations obtained by merging several different databases and datasets to obtain all the measures needed for the study, and dropping the observations with missing values.

Our initial sample is from the DCA. Since our sample needs to access data from multiple sources, we used ticker symbols as the identifiers. Then, we identified 6,911 observations on 1,836 public firms which contain the ticker symbols in the DCA from 2001 to 2008. Since institutional complexity is the research focus, this study contains firms with foreign subsidiaries operating in three or more foreign countries in the sample. Consequently, 3,752 observations were dropped due to this criterion. Additionally, 196 firms with one year observations in the DCA were dropped, because these observations cannot reflect unobservable time variation. Subsequently, 2,963 observations on 635 firms were remained. Finally, after merging data from other sources and dropping observations with missing values, our final sample is an unbalanced panel data set which contains 296 firms and 1,340 observations.

\section{Statistical Model}

Since a panel data set was used, we employed fixed-effects regression models to test the hypotheses we proposed. For analyzing a panel data set, either fixed-effects regression models or random-effects regression models could be applied. However, the Hausman specification test indicated that the fixed-effects regression models were more suitable to this study compared with the random-effects regression models. Therefore, the 
fixed-effects regression models were selected. Additionally, predictors entered into the regression models after standardized.

\section{Variables}

Below the definition and operationalization of variables is introduced. The summary of variable definition and data sources is in Table 2.1.

\section{Table 2.1 Variable Definition and Data Sources for Essay 1}

\begin{tabular}{|c|c|c|}
\hline Variable & Description & Source \\
\hline TMT total compensation & $\begin{array}{l}\text { ln } \sum(\text { salary }+ \text { bonus }+ \text { stock option }+ \\
\text { restrecited stock }+ \text { long }- \text { term incentive plan }+ \\
\text { other compensation }) / n ; n \text { : the number of top executives in } \\
\text { an MNE }\end{array}$ & 1 \\
\hline $\begin{array}{l}\text { TMT long-term } \\
\text { compensation mix }\end{array}$ & $\begin{array}{l}\sum(\text { stock option }+ \text { restricted stock }+ \text { long }- \\
\text { term incentive plan }) / \text { total compensation } * 1 / n * 100 ; n \text { : } \\
\text { the number of top executives in an MNE }\end{array}$ & 1 \\
\hline Political complexity & $\begin{array}{l}\text { Political complexity = coefficient of variation on the } \\
\text { POLCON distance (pccv); } \\
\text { Calculation steps: } \\
\text { Step 1: Calculation for Political distance } \text { P }_{j}= \\
\text { abs }\left(P O L C O N_{j}-P O L C O N_{u s}\right) ; j \text { : a host country which a } \\
\text { foreign subsidiary of an MNE located } \\
\text { Step 2: pccv }=\left(\text { sd } \text { of Political distance }_{j} / \text { mean of }\right. \\
\left.\text { Political distance }_{j}\right)\end{array}$ & 2 \\
\hline Cultural complexity & $\begin{array}{l}\text { Cultural complexity = coefficient of variation on the GLOBAL } \\
\text { PROJECT's cultural distance }(\mathrm{cccv}) ; \\
\text { Calculation steps: } \\
\text { Step 1: Calculation for Cultural distance } e_{i}=\sum_{i=1}^{9}\left(I_{i j}-\right. \\
\left.\left.I_{i u s}\right)^{2} / V_{i}\right) * 1 / 9 ; j \text { : a host country; } i \text { : a dimension of culture; } V \text { : } \\
\text { variance of a cultural dimension; This measure is similar to } \\
\text { Kogut and Singh's (1988) indicator of cultural distance } \\
\text { Step 2: cccv }=\left(\text { sd } \text { of } \text { Cultural distance }_{i} / \text { mean of }\right. \\
\left.\text { Cultural distance } e_{i}\right)\end{array}$ & 3 \\
\hline Industry performance & $\begin{array}{l}\text { Industry } \mathrm{ROA}= \\
\sum_{i}^{n}(\text { net } \text { income } / \text { total assets }) * 1 / n * 100 \\
n: \text { the total number of firms with the same three-digits SIC } \\
\text { codes excluding the focal firm }\end{array}$ & 4 \\
\hline TMT size & A count of the total number of top officers in an MNE & 1 \\
\hline Firm size & The total assets of an MNE & 4 \\
\hline Firm performance & $\mathrm{ROA}=$ net income/total assets $* 100$ & 4 \\
\hline CEO duality & Dummy $=1$ if a CEO is also the chairperson and 0 otherwise & 5 \\
\hline
\end{tabular}




\begin{tabular}{|l|l|l|}
\hline Outside director ratio & $\begin{array}{l}\text { The number of outside directors/the number of total } \\
\text { directors } 100\end{array}$ & 5 \\
\hline R\&D intensity & R\&D spending/total sales $* 100$ & 4 \\
\hline Product diversification & $\begin{array}{l}\text { Chatterjee and Wernerfelt's measure } \\
\text { Product diversification }=\sum_{j} d_{i h} p_{i j} \\
d_{i h} \text { it is a distance of a business segment to the largest } \\
\text { business segment of an MNE based on SIC code; } 0 \text { if they } \\
\text { have the same four-digit SIC codes; } 1 \text { if they have the same } \\
\text { three-digit SIC code, and etc. } \\
\\
p_{i j} \text { : sales in the } j \text { business segment/total sales }\end{array}$ & 6 \\
\hline International diversification & $\begin{array}{l}\text { The number of host countries which an MNE has subsidiaries } \\
\text { located. }\end{array}$ & 7 \\
\hline
\end{tabular}

Note: 1. Compustat ExecuComp database; 2. Henisz's Political Constraint Index (POLCON) dataset; 3. House's Global Project; 4. Compustat database; 5. Corporate Library database; 6. Compustat Segment database; 7. Directory of Corporate Affiliations database

\section{Dependent Variables}

The dependent variables are the average TMT total compensation and average TMT long-term compensation mix. The total compensation was the natural logarithm of the sum of all kinds of compensation, including salary, bonus, stock option, and others, that top executives received in a given year (e.g. Carpenter, Sanders, \& Gregersen, 2001; Sanders \& Carpenter, 1998). Additionally, TMT long-term compensation ratio was calculated as long-term compensation, including stock options, restricted stock, and long-term incentive plans, over total compensation (Sanders \& Carpenter, 1998).

\section{Independent Variables}

Firm's political complexity. This study used Henisz's political constraints (POLCON) to measure a nation's political institutions. The POLCON indicator reflects the extent to which the choice of public policy is constrained by the structure of political institutions (Henisz, 2000). This indicator has been widely used by past research (Delios \& Henisz, 2003; Henisz, 2000). Each political distance was measured by the absolute value of the difference between the U.S.'s and a host country's scores on the POLCON indicator. 
Then, MNE's political complexity was measured by the coefficient of variation, which is commonly used for measuring the dispersion of a continuous variable. It was calculated as the ratio between standard deviation and the mean of all political distances between an MNE and its foreign subsidiaries.

Firm's cultural complexity. In this study, we used House, Hanges, Javidan, Dorfman, and Gupta's (2004) the Global Leadership and Organizational Behavior Effectiveness (GLOBE) project to measure a nation's culture. The nine cultural dimensions of GLOBE project are: assertiveness, institutional collectivism, in-group collectivism, future orientation, gender egalitarianism, humane orientation, performance orientation, power distance, and uncertainty avoidance. Each cultural distance was measured by the absolute value of the difference between the U.S.'s and a host country's scores. Since a national culture contains multiple dimensions, Kogut and Singh (1988) developed a formula to reflect the overall cultural distance between two countries. This formula has been widely used by prior research (e.g., Morosini, Shane, Singh, 1998; Roth \& O'Donnell, 1996). Consequently, we adopted Kogut and Singh's (1988) formula to measure national cultural distances for the U.S. and all host countries of an MNE. This formula generates a composite index of the GLOBE project's nine national cultural dimensions. Then, cultural complexity was measured by the coefficient of variation of MNE's cultural distances.

\section{Control Variables}

Nine variables are controlled by this study. They are: (1) industry performance, (2) TMT size, (3) firm size, (4) firm performance, (5) CEO duality, (6) outside director ratio, (7) R\&D intensity, (8) product diversification, and (9) international diversification. 
Industry performance. Industry performance here reflects generally profitability of a firm's competitors in a particular industry. Average industry ROA which is the percentage of the industry net income over industry total assets is used to measure industry performance. The data on an industry are based on firms with the same three-digit standard industrial classification (SIC) code but exclude the focal firms.

TMT size. A greater number of TMT members may reflect managerial information processing as a whole. TMT size was measured by a count of the total number of top officers in an MNE (e.g. O’Reilly, Main, \& Crystal, 1988; Sanders \& Carpenter, 1998).

Firm size. Firm size is widely accepted to influence the executive compensation. In Tosi, Werner, Katz, and Gomez-Mejia's (2000) research, for example, they found that firm size explains about $40 \%$ of the variance of top executive compensation. Thus, firm size measured as total assets of a firm is controlled by this study.

Firm Performance. Firm performance is frequently proposed to determine the executive compensation. For example, Tosi et al. (2000) found that firm performance explains around $5 \%$ of the variance of top executive compensation. Firm performance was operationalized as return on asset (ROA). ROA is the percentage of the net income over total assets.

CEO duality. CEO power is an important concept in corporate governance (Westphal \& Zajac, 1995; Zajac \& Westphal, 1996), particularly in top executive compensation (Finkelstein \& Hambrick, 1989). Thus, this study employed CEO duality, CEO with chairperson status. In other words, the CEO holds both CEO and chairperson positions. This variable is a dummy variable. When a CEO is also the chairperson, the value of 1 was coded. Otherwise, the value of 0 was assigned. 
Outside director ratio. Board vigilance is widely proposed to affect the executive compensation (Finkelstein \& Hambrick, 1989) based on agency theory (Jensen \& Meckling, 1976). Thus, this study employed outside director ratio to reflect the extent of board vigilance. The outside director ratio was measured by the percentage of the number of outside directors over the total number of directors.

R\&D intensity. $R \& D$ intensity can be a dimension of the complexity of a firm (Henderson \& Fredrickson, 1996), and thus they were controlled by this study. This study measured $R \& D$ intensity by the ratio of $R \& D$ spending over total sales.

Product diversification. The relatedness of business segments of a firm can reflect the extent of needs for information-processing demands (Henderson \& Fredrickson, 1996). Therefore, product diversification was controlled for by this study with product diversification measured using Chatterjee and Wernerfelt's entropy measure (1991).

International diversification. International diversification reflects the presence of foreign operations in an MNE's portfolio, and additional information-processing demands (Sanders \& Carpenter, 1998). It is measured by the number of foreign countries in which the firms have subsidiaries located. The measure of international diversification is in line with prior research (e.g. Geringer et al. 1989).

\section{RESULTS}

Table 2.2 presents means, standard deviations, and correlations for all variables. We report results of fixed-effects linear regression analyses for TMT total compensation and TMT long-term compensation ratio in Tables 2.3 and 2.4, respectively. In Table 2.3, model 1 is the baseline model where only control variables are included. The model is significant $(F=2.77, p<.01)$ and several of the control variables are significant. In the 
baseline model, as hypothesized in past research, we predicted that firm size, firm performance, CEO duality, R\&D intensity, production diversification, and international diversification would be positively associated with the TMT total compensation. We found that the coefficients of firm size $(b=.295, p<.01)$ as well as CEO duality $(b=.072$, $p<.10)$ fit our predictions. However, the coefficients of firm performance $(b=.021, p$ $>.10), \mathrm{R} \& \mathrm{D}$ intensity $(b=-.004, p>.10)$, product diversification $(b=-.036, p>.10)$, and international diversification $(b=-.032, p>.10)$ are insignificant, although the $p$-value of firm performance is .176 which is close to the significant level of .10 .

In line with past research, we predicted that industry performance, TMT size, as well as outside director ratio would be negatively associated with the TMT total compensation. The coefficient of industry performance is $b=-.024(p<.10)$. We also found that the coefficient of TMT size $(b=-.039, p<.05)$ fits our prediction but not outside director ratio $(b=-.009, p>.10)$.

Models 2 and 3 add each of the MNE's institutional complexity measures, namely politic and cultural complexity, respectively. Model 4 presents the full model. All of these models are significant $(F=2.95, p<.01 ; F=2.88, p<.01 ; F=3.02, p<.001)$. Hypotheses 1 and 2 propose the MNE's institutional complexity will affect the TMT total compensation. Hypothesis 1 argues that the greater the MNE's political complexity a TMT facing, the greater the TMT total compensation. This hypothesis is supported in both Model $2(b=.057, p<.05)$ and the full Model $(b=.057, p<.05)$. Hypothesis 2 posits that MNE's cultural complexity will be positively associated with the TMT total compensation. The coefficients for MNE's cultural complexity are significant in Model 3 $(b=.075, p<.10)$ and Model $6(b=.074, p<.10)$. Therefore, Hypothesis 2 is supported. 
Table 2.2 Descriptive Statistics and Correlations for Essay 1

\begin{tabular}{|c|c|c|c|c|c|c|c|c|c|c|c|c|c|c|c|c|}
\hline & & Mean & SD & 1 & 2 & 3 & 4 & 5 & 6 & 7 & 8 & 9 & 10 & 11 & 12 & 13 \\
\hline 1 & $\begin{array}{l}\text { TMT total } \\
\text { compensation }\end{array}$ & 7.7 & 0.8 & 1.00 & & & & & & & & & & & & \\
\hline 2 & $\begin{array}{l}\text { TMT long-term } \\
\text { compensation } \\
\text { ratio }\end{array}$ & 61.1 & 20.4 & 0.72 & 1.00 & & & & & & & & & & & \\
\hline 3 & $\begin{array}{l}\text { Political } \\
\text { complexity }\end{array}$ & 1.0 & 0.4 & 0.11 & 0.09 & 1.00 & & & & & & & & & & \\
\hline 4 & $\begin{array}{l}\text { Cultural } \\
\text { complexity }\end{array}$ & 0.6 & 0.2 & 0.06 & 0.04 & -0.03 & 1.00 & & & & & & & & & \\
\hline 5 & $\begin{array}{l}\text { Industry } \\
\text { performance }\end{array}$ & 4.2 & 6.4 & 0.07 & 0.08 & 0.04 & -0.02 & 1.00 & & & & & & & & \\
\hline 6 & TMT size & 5.9 & 1.2 & 0.06 & -0.06 & 0.03 & 0.02 & -0.15 & 1.00 & & & & & & & \\
\hline 7 & Firm size & 15.4 & 100.6 & 0.22 & 0.07 & 0.02 & 0.01 & -0.02 & 0.13 & 1.00 & & & & & & \\
\hline 8 & $\begin{array}{l}\text { Firm } \\
\text { performance }\end{array}$ & 4.9 & 13.8 & 0.15 & 0.12 & 0.09 & 0.07 & 0.23 & -0.18 & -0.01 & 1.00 & & & & & \\
\hline 9 & CEO duality & 0.6 & 0.5 & 0.12 & 0.00 & 0.02 & 0.01 & 0.01 & -0.04 & 0.03 & 0.05 & 1.00 & & & & \\
\hline 10 & $\begin{array}{l}\text { Outside director } \\
\text { ratio }\end{array}$ & 83.1 & 9.0 & 0.16 & 0.22 & 0.04 & 0.00 & 0.08 & -0.04 & 0.00 & 0.07 & 0.10 & 1.00 & & & \\
\hline 11 & R\&D intensity & 8.0 & 9.0 & 0.04 & 0.10 & -0.09 & -0.12 & -0.02 & 0.04 & -0.06 & -0.21 & -0.10 & -0.05 & 1.00 & & \\
\hline 12 & $\begin{array}{l}\text { Product } \\
\text { diversification }\end{array}$ & 0.4 & 0.6 & 0.18 & 0.09 & 0.06 & 0.05 & -0.01 & 0.03 & 0.06 & -0.01 & 0.19 & 0.10 & -0.26 & 1.00 & \\
\hline 13 & $\begin{array}{l}\text { International } \\
\text { diversification }\end{array}$ & 11.6 & 10.8 & 0.39 & 0.25 & 0.23 & -0.11 & 0.10 & 0.06 & 0.09 & 0.11 & 0.11 & 0.14 & 0.08 & 0.19 & 1.00 \\
\hline
\end{tabular}

$\mathrm{N}=1340$; All correlations larger than .06 in absolute value are significant at the $\mathrm{p}=.05$ level. 
Table 2.3 Results of Fixed-effects Linear Regression Analyses for TMT Total Compensation

\begin{tabular}{|c|c|c|c|c|}
\hline & Model 1 & Model 2 & Model 3 & Model 4 \\
\hline Political complexity & & $\begin{array}{l}0.057^{*} \\
{[0.027]}\end{array}$ & & $\begin{array}{r}0.057^{*} \\
{[0.027]}\end{array}$ \\
\hline Cultural complexity & & & $\begin{array}{c}0.075 \dagger \\
{[0.039]}\end{array}$ & $\begin{array}{r}0.074 \dagger \\
{[0.039]}\end{array}$ \\
\hline Industry performance & $\begin{array}{l}-0.024 \dagger \\
{[0.014]}\end{array}$ & $\begin{array}{l}-0.027 \dagger \\
{[0.014]}\end{array}$ & $\begin{array}{l}-0.025 \dagger \\
{[0.014]}\end{array}$ & $\begin{array}{l}-0.028 * \\
{[0.014]}\end{array}$ \\
\hline TMT size & $\begin{array}{c}-0.039^{*} \\
{[0.015]}\end{array}$ & $\begin{array}{c}-0.039^{*} \\
{[0.015]}\end{array}$ & $\begin{array}{c}-0.039^{*} \\
{[0.015]}\end{array}$ & $\begin{array}{l}-0.039^{*} \\
{[0.015]}\end{array}$ \\
\hline Firm size & $\begin{array}{r}0.295^{* *} \\
{[0.101]}\end{array}$ & $\begin{array}{r}0.283^{* *} \\
{[0.101]}\end{array}$ & $\begin{array}{r}0.297 * * \\
{[0.101]}\end{array}$ & $\begin{array}{r}0.286^{* * *} \\
{[0.101]}\end{array}$ \\
\hline Firm performance & $\begin{array}{r}0.021 \\
{[0.015]}\end{array}$ & $\begin{array}{r}0.019 \\
{[0.015]}\end{array}$ & $\begin{array}{r}0.023 \\
{[0.015]}\end{array}$ & $\begin{array}{r}0.022 \\
{[0.015]}\end{array}$ \\
\hline CEO duality & $\begin{array}{r}0.072 \dagger \\
{[0.039]}\end{array}$ & $\begin{array}{c}0.075 \dagger \\
{[0.039]}\end{array}$ & $\begin{array}{c}0.069 \dagger \\
{[0.039]}\end{array}$ & $\begin{array}{l}0.073 \dagger \\
{[0.039]}\end{array}$ \\
\hline Outside director ratio & $\begin{array}{r}-0.009 \\
{[0.021]}\end{array}$ & $\begin{array}{r}-0.008 \\
{[0.021]}\end{array}$ & $\begin{array}{r}-0.008 \\
{[0.021]}\end{array}$ & $\begin{array}{r}-0.008 \\
{[0.021]}\end{array}$ \\
\hline R\&D intensity & $\begin{array}{r}-0.004 \\
{[0.033]}\end{array}$ & $\begin{array}{c}-0.003 \\
{[0.033]}\end{array}$ & $\begin{array}{r}-0.001 \\
{[0.033]}\end{array}$ & $\begin{array}{r}-0.001 \\
{[0.033]}\end{array}$ \\
\hline $\begin{array}{l}\text { Product } \\
\text { diversification }\end{array}$ & $\begin{array}{r}-0.036 \\
{[0.037]}\end{array}$ & $\begin{array}{r}-0.036 \\
{[0.037]}\end{array}$ & $\begin{array}{r}-0.032 \\
{[0.037]}\end{array}$ & $\begin{array}{r}-0.033 \\
{[0.037]}\end{array}$ \\
\hline $\begin{array}{l}\text { International } \\
\text { diversification }\end{array}$ & $\begin{array}{r}-0.032 \\
{[0.045]}\end{array}$ & $\begin{array}{r}-0.043 \\
{[0.045]}\end{array}$ & $\begin{array}{r}-0.018 \\
{[0.046]}\end{array}$ & $\begin{array}{r}-0.029 \\
{[0.046]}\end{array}$ \\
\hline Constant & $\begin{array}{r}7.624 * * * \\
{[0.026]}\end{array}$ & $\begin{array}{r}7.622 * * * \\
{[0.026]}\end{array}$ & $\begin{array}{r}7.625^{* * * *} \\
{[0.026]}\end{array}$ & $\begin{array}{r}7.623^{* * *} \\
{[0.026]}\end{array}$ \\
\hline No. of firms & 296 & 296 & 296 & 296 \\
\hline No. of observations & 1340 & 1340 & 1340 & 1340 \\
\hline F value & $2.77 * *$ & $2.95 * *$ & $2.88 * *$ & $3.02 * * *$ \\
\hline
\end{tabular}

Notes:

1. S.E. in square brackets.

2. $* * * \mathrm{p}<0.001 ; * * \mathrm{p}<0.01 ; * \mathrm{p}<0.05 ; \dagger \mathrm{p}<0.10$; t test are all two-tailed tests. 
Table 2.4 reports the results of fixed-effects linear regression analyses for TMT long-term compensation ratio. Model 5, the baseline model, only includes control variables. The model is significant $(F=6.74, p<.001)$ as well as three control variables are significant. They are TMT size $(b=-3.169, p<.001)$, firm size $(b=13.501, p<.01)$, as well as CEO duality $(b=-2.615, p<.10)$ which are all fit our predictions. Although the coefficients of firm performance $(b=.843, p>.10)$ and outside director ratio $(b=$ $1.168, p>.10)$ are insignificant, their $p$-values, .151 and .146 , are very close to the significant level of .10 .

Then, from model 6 and 7, two dimensions of MNE's institutional complexity were added separately. Model 8 is the full model. Again all of the models are significant $(p<.001)$. Hypothesis 3 and 4 posits that the MNE's institutional complexity will affect the average TMT long-term compensation ratio. Hypothesis 3 proposes that the MNE's political complexity is positively associated with the average TMT long-term compensation ratio. The results show that $b=3.745$ and $p<.001$ in model 6 and $b=$ 3.723 and $p<.001$ in model 8 . Therefore, hypothesis 3 is supported. Hypothesis 4 proposes that MNE's cultural complexity will be positively related to the average TMT long-term compensation ratio. The coefficient for MNE's cultural complexity is significant in Model $7(b=3.574, p<.05)$ as well as the full model $(b=3.526, p<.05)$, so hypothesis 4 also receives a support. 
Table 2.4 Results of fixed-effects linear regression analyses for TMT long-term compensation ratio

\begin{tabular}{lrrrr}
\hline & Model 5 & Model 6 & Model 7 & Model 8 \\
\hline Political complexity & & $3.745^{* * *}$ & & $3.723^{* * *}$ \\
Cultural complexity & & {$[1.047]$} & & {$[1.045]$} \\
& & & $3.574^{*}$ & $3.526^{*}$ \\
Industry performance & -0.271 & -0.435 & {$[1.500]$} & {$[1.491]$} \\
& {$[0.536]$} & {$[0.535]$} & -0.316 & -0.479 \\
TMT size & $-3.169^{* * *}$ & $-3.169^{* * *}$ & $-3.159^{* * *}$ & $-3.159^{* * *}$ \\
& {$[0.585]$} & {$[0.582]$} & {$[0.584]$} & {$[0.581]$} \\
Firm size & $13.501^{* *}$ & $12.721^{* *}$ & $13.609^{* * *}$ & $12.832^{* *}$ \\
& {$[3.902]$} & {$[3.886]$} & {$[3.894]$} & {$[3.878]$} \\
Firm performance & 0.843 & 0.761 & 0.976 & 0.894 \\
& {$[0.587]$} & {$[0.584]$} & {$[0.588]$} & {$[0.585]$} \\
CEO duality & $-2.615 \dagger$ & -2.405 & $-2.717 \dagger$ & $-2.507 \dagger$ \\
& {$[1.518]$} & {$[1.511]$} & {$[1.515]$} & {$[1.508]$} \\
Outside director ratio & 1.168 & 1.183 & 1.194 & 1.208 \\
& {$[0.802]$} & {$[0.798]$} & {$[0.801]$} & {$[0.796]$} \\
R\&D intensity & -0.191 & -0.151 & -0.078 & -0.040 \\
Product & {$[1.276]$} & {$[1.269]$} & {$[1.274]$} & {$[1.267]$} \\
diversification & -1.555 & -1.581 & -1.399 & -1.426 \\
International & {$[1.437]$} & {$[1.429]$} & {$[1.435]$} & {$[1.427]$} \\
diversification & -0.095 & -0.776 & 0.573 & -0.113 \\
Constant & {$[1.756]$} & {$[1.756]$} & {$[1.774]$} & {$[1.775]$} \\
& $62.736^{* * *}$ & $62.605^{* * *}$ & $62.799^{* * *}$ & $62.668^{* * *}$ \\
\hline No. of firms & {$[1.027]$} & {$[1.022]$} & {$[1.025]$} & {$[1.020]$} \\
No. of observations & 296 & 296 & 296 & 296 \\
F value & 1340 & 1340 & 1340 & 1340 \\
\hline Not & $6.74^{* * *}$ & $7.41^{* * *}$ & $6.66^{* * *}$ & $7.27^{* * *}$ \\
\hline
\end{tabular}

Notes:

1. S.E. in square brackets.

2. ${ }^{* * *} \mathrm{p}<0.001 ;{ }^{* *} \mathrm{p}<0.01 ; * \mathrm{p}<0.05 ; \dagger \mathrm{p}<0.10$; t test are all two-tailed tests. 


\section{DISCUSSION AND CONCLUSION}

In this study, we propose that MNE's institutional complexity is yet another dimension of complexity that faces top executives, increasing the demands on their information-processing capabilities. In line with past research (Henderson \& Fredrickson, 1996; Sanders \& Carpenter, 1998), we propose that such complexity will then lead to additional compensation. Additionally, institutional complexity creates an environment which board monitoring may not be able to function effectively, and long-term performance compensation should be emphasized. Our results show strong support for the theory presented. We find that both greater MNE's political and cultural complexity can lead to greater the average TMT total compensation as well as the proportion of longterm compensation.

The contributions of this study have the following three aspects. First, these findings demonstrate one more time that national institutions are essential elements in MNEs strategic decisions, such as the choice of entry mode (e.g., Contractor \& Kundu, 1998) or organizational practice transfer (e.g., Kostova, 1999), and ultimately impacting MNE performance (e.g., Chacar et al., 2010). The findings also lend support to the propositions made linking international diversification to compensation (Carpenter et al., 2001; Sanders \& Carpenter, 1998). With the exception of Sanders and colleagues, researchers have not yet to examine the impact of international elements on compensation. Our findings demonstrate that the importance of institutional environments faced by MNEs on their executive compensation to complement the large body of compensation research in the national arena and on internal factors (e.g., Henderson \& Fredrickson, 1996; Jensen \& Murphy, 1990). 
Second, this study shows that institutional complexity faced by MNEs is another level of elements in addition to the extent of international diversification. Past research largely examines the effects of the extent of international diversification on MNE performance and other outcomes (Contractor et al., 2003; Sanders \& Carpenter, 1998). This line of research has been criticized by leaving the core elements of MNEs untouched (Verbeke, Li, \& Goerzen, 2009). By controlling the extent of international diversification, this study demonstrates that institutional complexity faced by MNEs indeed affects top executive compensation.

Third, we also propose a novel way to zero in very precisely the actual national institutional complexity of an MNE by examining the actual institutional environments facing its web of subsidiaries. This approach is similar to the one developed by Goerzen and Beamish (2003) which examines the relationship between an MNE's environmental complexity and MNE performance. Since MNEs simultaneously manage multiple subsidiaries, this study emphasizes the importance of the MNE's institutional complexity, and more specifically dispersion within the MNE network. This approach can help supplement research focused on dyadic relationships between home and host countries (e.g., Kogut \& Singh, 1988).

Managerial implications of this study are below. First, most researchers and practitioners concern about whether top executives use their power to appropriate more rent and receive greater compensation from their firms. However, this line of view merely focuses on avoiding the self-interesting behaviors of top executives. To attract potential executive candidates from markets and retain capable executives, the design of executive compensation should base on the executive job requirements from the economics viewpoint. 
Our results offer valuable insights on the linkage between institutional complexity and executive compensation. Additionally, monitoring function of a board and executive incentives are traditionally viewed as two arms to protect the interests of shareholders. Once one cannot fully function, another should substitute it. Since institutional complexity may create challenges for boards to effectively monitor executives, the findings of this study suggest that the boards can use the executive long-term compensation scheme to direct the interests of executives toward those of shareholders.

This study is not without limitations. Three limitations, at least, of this study can pave some avenues for future research. First, this study only examines the impact of institutional complexity on executive compensation. It is likely that this institutional complexity will also influence other elements within the MNEs, as well as strategic choices and performance. For example, future research may examine how greater institutional complexity affects boards of directors' compensation and composition. Second, this study focuses on the overall impacts of institutional complexity on executive compensation. However, we may expect that additional institutional complexity associated with entering new foreign countries may have greater impacts on the overall institutional complexity faced by MNEs (Hutzschenreuter \& Voll, 2007). Thus, future research may explore the impact of additional institutional complexity on the change of executive compensation. Finally, the design of internal elements may alleviate the top executives' information load in an MNE. These internal elements include MNE's strategy (Wolf \& Egelhoff, 2002), structure (Egelhoff, 1991), and control mode (Chen, Park, \& Newburry, 2009). Future research hence may explore how these elements play as a moderating role on the relationship between institutional complexity and executive compensation. 


\section{REFERENCES}

Ahuja, G. \& Lampert, C. M. 2001. Entrepreneurship in the large corporation: A longitudinal study of how established firms create breakthrough inventions. Strategic Management Journal, 22(6-7): 521-543.

Anderson, E. \& Gatignon, H. 1986. Modes of foreign entry: A transaction cost analysis and propositions. Journal of International Business Studies, 17(3): 1-26.

Andrews, K. R. 1971. The Concept of Corporate Strategy. Homewood, IL: Irwin.

Barkema, H. G. \& Drogendijk, R. 2007. Internationalising in small, incremental or larger steps? Journal of International Business Studies, 38(7): 1132-1148.

Birkinshaw, J., Toulan, O., \& Arnold, D. 2001. Global account management in multinational corporations: theory and evidence. Journal of International Business Studies, 32(2): 231-248.

Boddewyn, J. J. 1988. Political aspects of MNE theory. Journal of International Business Studies, 19(3): 341-363.

Carpenter, M. A., Sanders, G., \& Gregersen, H. B. 2001. Bundling human capital with organizational context: The impact of international assignment experience on multinational firm performance and CEO pay. The Academy of Management Journal, 44(3): 493-511.

Caves, R. 1986. Multinational Enterprise and Economic Activity. Cambridge: Cambridge University Press.

Chacar, A. \& Vissa, B. 2005. Are emerging economies less efficient? Performance persistence and the impact of business group affiliation. Strategic Management Journal, 26(10): 933-946.

Chacar, A. S., Newburry, W., \& Vissa, B. 2010. Bringing Institutions into Performance Persistence Research: Exploring the Impact of the Product, Financial and Labor Market Institutions. Journal of International Business Studies, 41(7): 1119-1140.

Chandler, A. D. 1962. Strategy and structure: Chapters in the History of American Industrial Enterprise. Cambridge, MA: MIT Press.

Chatterjee, S. \& Wernerfelt, B. 1991. The link between resources and type of diversification: Theory and evidence. Strategic Management Journal, 12(1): 33-48. 
Chen, D., Park, S. H., \& Newburry, W. 2009. Parent contribution and organizational control in international joint ventures. Strategic Management Journal, 30(11): 11331156.

Coase, R. H. 1937. The nature of the firm. Economica, 4(16): 386-405.

Cohen, W. M. \& Levinthal, D. A. 1990. Absorptive capacity: a new perspective on learning and innovation. Administrative science quarterly, 35(1): 128-152.

Contractor, F. J. \& Kundu, S. K. 1998. Modal Choice in a World of Alliances: Analyzing Organizational Forms in the International Hotel Sector. Journal of International Business Studies, 29(2): 325-358.

Contractor, F. J., Kundu, S. K., \& Hsu, C. C. 2003. A Three-Stage Theory of International Expansion: The Link between Multinationality and Performance in the Service Sector. Journal of international business studies, 34(1): 5-19.

Daft, R. L. \& Lengel, R. H. 1986. Organizational information requirements, media richness and structural design. Management Science, 32(5): 554-571.

Datta, D. K., Musteen, M., \& Herrmann, P. 2009. Board characteristics, managerial incentives, and the choice between foreign acquisitions and international joint ventures. Journal of Management, 35(4): 928-953.

Delios, A. \& Henisz, W. J. 2003. Political Hazards, Experience, and Sequential Entry Strategies: The International Expansion of Japanse Firms, 1980-1998. Strategic Management Journal, 24(11): 1153-1164.

Egelhoff, W. G. 1982. Strategy and structure in multinational corporations: An information-processing approach. Administrative Science Quarterly, 27(3): 435458.

Egelhoff, W. G. 1991. Information-processing theory and the multinational enterprise. Journal of International Business Studies, 22(3): 341-368.

Eisenhardt, K. M. 1989. Agency theory: An assessment and review. The Academy of Management Review, 14(1): 57-74.

Erramilli, M. K. 1991. The experience factor in foreign market entry behavior of service firms. Journal of International Business Studies, 22(3): 479-501.

Finkelstein, S. \& Hambrick, D. C. 1989. Chief executive compensation: A study of the intersection of markets and political processes. Strategic Management Journal, 10(2): 121-134. 
Geringer, J. M., Beamish, P. W., \& DaCosta, R. C. 1989. Diversification strategy and internationalization: Implications for MNE performance. Strategic Management Journal, 10(2): 109-119.

Ghoshal, S. \& Nohria, N. 1989. Internal differentiation within multinational corporations. Strategic Management Journal, 10(4): 323-337.

Ghoshal, S. \& Bartlett, C. A. 1990. The multinational corporation as an interorganizational network. The Academy of Management Review, 15(4): 603-625.

Ghoshal, S., Korine, H., \& Szulanski, G. 1994. Interunit communication in multinational corporations. Management Science, 40(1): 96-110.

Goerzen, A. \& Beamish, P. W. 2003. Geographic scope and multinational enterprise performance. Strategic Management Journal, 24(13): 1289-1306.

Gomez-Mejia, L. R. \& Palich, L. E. 1997. Cultural Diversity and the Performance of Multinational Firms. Journal of International Business Studies, 28(2): 305-339.

Henderson, A. D. \& Fredrickson, J. W. 1996. Information-processing demands as a determinant of CEO compensation. The Academy of Management Journal, 39(3): 575-606.

Henisz, W. J. 2000. The institutional environment for multinational investment. Journal of Law, Economics, and Organization, 16(2): 334-364.

Hofstede, G. H. 1984. Culture's consequences: International differences in work-related values, Thousand Oaks, CA: Sage Publications, Inc.

House, R. J. 2004. Culture, leadership, and organizations: The GLOBE study of 62 societies. Thousand Oaks, CA: Sage Publications, Inc.

Hutzschenreuter, T. \& Voll, J. C. 2007. Performance effects of "added cultural distance" in the path of international expansion: the case of German multinational enterprises. Journal of International Business Studies, 39(1): 53-70.

Hymer, S. H. 1976. The international operations of national firms: A study of direct foreign investment. Cambridge, MA: MIT press.

Jensen, M. C. \& Meckling, W. H. 1976. Theory of the firm: Managerial behavior, agency costs and ownership structure. Journal of financial economics, 3(4): 305-360.

Jensen, M. C. \& Murphy, K. J. 1990. Performance pay and top-management incentives. The Journal of Political Economy, 98(2): 225-264. 
Johanson, J. \& Vahlne, J. E. 1977. The internationalization process of the firm-a model of knowledge development and increasing foreign market commitments. Journal of international business studies, 8(1): 23-32.

Johanson, J. \& Vahlne, J. E. 1990. The mechanism of internationalisation. International marketing review, 7(4): 11-24.

Jones, G. R. \& Hill, C. W. L. 1988. Transaction cost analysis of strategy-structure choice. Strategic Management Journal, 9(2): 159-172.

Kogut, B. \& Singh, H. 1988. The effect of national culture on the choice of entry mode. Journal of international business studies, 19(3): 411-432.

Kostova, T. 1999. Transnational transfer of strategic organizational practices: A contextual perspective. Academy of Management Review, 24(2): 308-324.

Kostova, T. \& Zaheer, S. 1999. Organizational legitimacy under conditions of complexity: The case of the multinational enterprise. The Academy of Management Review, 24(1): 64-81.

Kostova, T. \& Roth, K. 2002. Adoption of an organizational practice by subsidiaries of multinational corporations: Institutional and relational effects. The Academy of Management Journal, 45(1): 215-233.

Leff, N. H. 1978. Industrial organization and entrepreneurship in the developing countries: The economic groups. Economic Development and Cultural Change, 26(4): 661675 .

Mace, M. L. 1971. Directors: Myth and reality. Cambridge, MA: Harvard Business School Press.

Meyer, K. E., Mudambi, R., \& Narula, R. 2011. Multinational enterprises and local contexts: the opportunities and challenges of multiple embeddedness. Journal of Management Studies, 48(2): 235-252.

Mintzberg, H. 1973. The nature of managerial work. Englewood Cliffs, NJ: HarperCollins Publishers.

Morosini, P., Shane, S., \& Singh, H. 1998. National Cultural Distance and Cross-Border Acquisition Performance. Journal of International Business Studies, 29(1): 137-158.

Mudambi, R. \& Navarra, P. 2002. Institutions and internation business: A theoretical overview. International Business Review, 11(6): 635-646. 
Murtha, T. P. \& Lenway, S. A. 1994. Country capabilities and the strategic state: How national political institutions affect multinational corporations' strategies. Strategic Management Journal, 15(S2): 113-129.

Nelson, R. R. \& Winter, S. G. 1982. An Evolutionary Theory of Economic Change. Cambridge, MA: Harvard University Press.

North, D. C. 1990. Institutions, institutional change, and economic performance: Cambridge Univ Pr.

Oliver, C. 1991. Strategic responses to institutional processes. The Academy of Management Review, 16(1): 145-179.

O'Reilly Iii, C. A., Main, B. G., \& Crystal, G. S. 1988. CEO compensation as tournament and social comparison: A tale of two theories. Administrative Science Quarterly, 33(2): 257-274.

Prahalad, C. K. \& Bettis, R. A. 1986. The dominant logic: A new linkage between diversity and performance. Strategic Management Journal, 7(6): 485-501.

Roth, K. \& O'Donnell, S. 1996. Foreign subsidiary compensation strategy: An agency theory perspective. The Academy of Management Journal, 39(3): 678-703.

Sanders, W. M. G. \& Carpenter, M. A. 1998. Internationalization and firm governance: The roles of CEO compensation, top team composition, and board structure. The Academy of Management Journal, 41(2): 158-178.

Schwens, C., Eiche, J., \& Kabst, R. 2011. The moderating impact of informal institutional distance and formal institutional risk on SME entry mode choice. Journal of Management Studies, 48(2): 330-351.

Shane, S., Venkataraman, S., \& MacMillan, I. 1995. Cultural differences in innovation championing strategies. Journal of Management, 21(5): 931-952.

Simon, J. D. 1984. A theoretical perspective on political risk. Journal of International Business Studies, 15(3): 123-143.

Thompson, J. D. 1967. Organizations in action. New York: McGraw-Hill.

Tosi, H. L., Werner, S., Katz, J. P., \& Gomez-Mejia, L. R. 2000. How much does performance matter? A meta-analysis of CEO pay studies. Journal of Management, 26(2): 301-339.

Tushman, M. L. \& Nadler, D. A. 1978. Information processing as an integrating concept in organizational design. Academy of Management Review, 3(3): 613-624. 
Ungson, G. R., Braunstein, D. N., \& Hall, P. D. 1981. Managerial information processing: A research review. Administrative Science Quarterly, 26(1): 116-134.

Verbeke, A., Li, L., \& Goerzen, A. 2009. Toward More Effective Research on the Multinationality-Performance Relationship. Management International Review, 49(2): 149-161.

Von Glinow, M. A., Shapiro, D. L., \& Brett, J. M. 2004. Can we talk, and should we? Managing emotional conflict in multicultural teams. Academy of Management Review, 29(4): 578-592.

Westphal, J. D. \& Zajac, E. J. 1995. Who shall govern? CEO board power, demographic similarity, and new director selection. Administrative Science Quarterly, 40(1): 6083.

Williamson, O. E. 1975. Markets and hierarchies, analysis and antitrust implications. New York: Free Press.

Wolf, J. \& Egelhoff, W. G. 2002. A reexamination and extension of international strategy-structure theory. Strategic Management Journal, 23(2): 181-189.

Zaheer, S. 1995. Overcoming the liability of foreignness. The Academy of Management Journal, 38(2): 341-363.

Zajac, E. J. \& Westphal, J. D. 1994. The costs and benefits of managerial incentives and monitoring in large US corporations: when is more not better? Strategic Management Journal, 15(S1): 121-142.

Zajac, E. J. \& Westphal, J. D. 1996. Director Reputation, CEO-Board Power, and the Dynamics of Board Interlocks. Administrative Science Quarterly, 41(3): 507-529.

Zollo, M. \& Winter, S. G. 2002. Deliberate learning and the evolution of dynamic capabilities. Organization Science, 13(3): 339-351. 


\section{TOP MANAGEMENT TEAM'S SOCIAL CAPITAL AND ITS MODERATING ROLE ON VALUE CREATION AND \\ APPROPRIATION BY THE CEOS}

\section{INTRODUCTION}

Investigating why some firms outperform others is a fundamental question in the field of strategic management (Rumelt, Schendel, \& Teece, 1991). Thus, drawing from the resource-based view of the firm (Barney, 1991; Wernerfelt, 1984), abundant studies tried to answer this question (see Newbert, 2007 for a comprehensive review). For instance, past research has documented that superior managerial capabilities, not only intellectual capital but also social capital, can be a source of competitive advantage, and are associated with greater firm performance (e.g., Carpenter, Sanders, and Gregerssn, 2001; Geletkanycz \& Hambrick, 1997; Miller \& Shamsie, 2001). However, without exploring the rent appropriation within a firm, the answer is incomplete (Coff, 1999). Prior research, additionally, has indicated that top executives play a vital role on rent creation as well as rent appropriation (Castanias \& Helfat, 1991\& 2001; Coff, 1999). Thus, examining both rent creation and rent appropriation, this study aims to explore the effects of chief executive officers' (CEOs') managerial capabilities, including intellectual and social capital, on firm performance and CEO total compensation. This study, furthermore, explores how the social capital of a top management team (TMT) affects the above relationships.

One stream of research (e.g., Newbert, 2007) has focused on managerial capabilities as a construct frequently used in the research of the resource-based view of the firm. For example, viewing international assignment experience as 
valuable intellectual capital which can equip executives to better manage foreign operations, Carpenter et al. (2001) demonstrated that this experience can facilitate performance of multinational corporations. Additionally, Geletkanycz and Hambrick (1997) demonstrated that the external intraindustry and extraindustry social ties can provide necessary information to confirm the effectiveness of strategic moves and, in turn, affect firm performance.

On the other hand, rent appropriation is an emerging topic in strategic management and is starting to get attention from scholars. For example, Chacar and Coff (2000) argued that star stock analysts, as knowledge workers, have private information about their firms, and thus appropriate a large part of rents, so their firms increase the volume of businesses but not firm profitability. In addition, Blyler and Coff (2003) proposed that the social capital of employees determines their rent appropriation capabilities. Since top executives are at the top of a firm, they tend to have more opportunities to appropriate rents. This stream of research examines the phenomenon of managerial rent appropriation through insider trading of shares. For example, Coff and Lee (2003) proposed that top executives have private information on their firms, and thus they can gain personal benefits from the $R \& D$ investments. In a similar vein, since top executives possess more knowledge regarding the potential values of their firm's patents, they can acquire personal gains from a firm's patent applications (Ahuja, Coff, \& Lee, 2005).

Not only the CEO but also the other TMT members are at the top of a firm (Hambrick, 2007; Pettigrew, 1992). They jointly make strategic decisions for their firm so the CEO as well as their TMT members should have impacts on firm performance. Additionally, an emerging line of research has indicated 
the importance of understanding interactions between CEOs and their TMT members (Buyl, Boone, Hendriks, \& Matthyssens, 2011; Klimoski \& Koles, 2001). Since the social capital of a TMT reflects the information channels of TMT members (Geletkanycz \& Hambrick, 1997; Granovetter, 1985), it should enhance the exercise of CEO's managerial capabilities based on the complementary viewpoint (Amit \& Schoemaker, 1993). On the other hand, TMT social capital may curtail the CEO's ability on rent appropriation, because the value of the CEO's managerial capabilities is dependent on other TMT members' social capital.

Although rent creation and appropriation have drawn considerable attention, researchers have mostly examined rent appropriation through insider trading of shares. However, executives can get personal gain from insider trading as well as their compensation. Moreover, how the social capital of the TMT affects the CEO's ability on rent creation and rent appropriation is, in comparison, less investigated by prior research. Thus, based on the social embeddedness lens, this study develops a strategic contingency theory of CEO rent-creation and rent-appropriation. Greater social capital, or social ties, of TMT members can assist their CEO to access a broad array of information and to leverage critical resources from the external. Therefore, the social capital of a TMT should facilitate the CEO's managerial capabilities, including intellectual and social capital, in the rent-creation process. On the other hand, the exercise of a CEO's managerial capabilities will rely on the TMT social capital. Consequently, greater TMT social capital may lessen the CEO's power on rent appropriation. Based on a sample of 548 U.S. firms and 2,010 observations from 2003 to 2009, this study found that greater TMT social capital, indeed, 
facilitates the effects of the CEO intellectual and social capital on firm performance.

The remainder of this study unfolds as follows. First, we discuss theoretically how managerial capabilities translate into rent creation and the moderating role of TMT social capital. In the following section, we discuss the same question but related to rent appropriation. Then, the methods of this study, including the sample, the operationalization of variables, and statistical models, are discussed. Next, we present empirical results of this study. Finally, we identify the contributions and limitations of this study as well as discuss avenues for future research.

\section{MANAGERIAL RENT CREATION}

Top executives have long been argued to be important determinants of organizational outcomes (e.g. Andrews, 1971; Hambrick \& Mason, 1984). From the strategic choice perspective, top management - the CEOs and their TMT members - are the agents who make strategic choices based on the analysis of internal resources and external environments, and thus the outcomes of these strategic choices are determined by these top executives (e.g., Andrews, 1971; Hambrick \& Mason, 1984). In other words, this viewpoint implicitly proposes that organizational performance is affected by the quality or efficiency of top executives.

To examine the relationship between managerial resources and rents, scholars further argued that top management can be the vital resource for rent creation of a firm (Adner \& Helfat, 2003; Castanias \& Helfat, 1991 \& 2001). For example, Castanias and Helfat (1991) proposed that managerial skills include generic, industry-related, and firm-specific skills. Because these skills 
are scarce, they generate Ricardian rents. In addition, industry-related and firmspecific skills are best used in particular circumstances. The use of them in other circumstances, such as other firms or industries, may decrease their utilities so these skills may generate quasi-rents. To summarize, not only do all managerial skills generate Ricardian rents because of the scarce traits of managerial skills, but also certain types of skills, such as industry-related and firm-specific, can create quasi-rents, based on their specificity.

Since strategic management research is concerned with the long-term rent-generation ability of a resource, Castanias and Helfat (1991) further argued that managerial skills fit the criteria of isolating mechanisms (Rumelt, 1984) from at least three viewpoints. First, most top executive's tasks involve tacit and hardly codifiable rather than explicit knowledge so it is difficult to identify the causal relationship between managerial skills and organizational outcomes. Consequently, managerial skills may have the characteristic of causal ambiguity. Second, because these skills maybe tailored to particular firms or industries, they are likely to have the trait of specialization. Third, not only is it difficult for other competitors to imitate a firm's managerial knowledge, but also these managerial talents are not widely dispersed in each firm. Thus, managerial skills tend to be unique.

In addition, Castanias and Helfat (2001) employed the lens of the resource-based view of a firm to examine managerial resources. Managerial resources are not homogeneous since each firm has a different quality and quantity of top managers. Although top executives can migrate to other firms, some of their skills or knowledge cannot be mobilized, because they can only be applied in particular contexts. Thus, managerial resources meet two basic 
assumptions of the resource-based view of a firm. Castanias and Helfat (2001) further argued that managerial resources are valuable, unique, difficult to imitate, and difficult to substitute, and thus are a source of sustained competitive advantages. In sum, based on the above arguments, managerial resources not only generate a short-term performance but also lead to sustained competitive advantages.

Business environments are dynamic rather than static. In order to achieve the sustained competitive advantages, a firm needs to develop dynamic capabilities to continually coordinate and reconfigure its resources to meet the changing environments (e.g. Teece, Pisano, \& Shuen, 1997). From the dynamic capabilities perspective, Augier and Teece (2009) posited that management plays an important role in developing dynamic capabilities. They proposed that management creates, maintains, or changes organizational routines, integrates resources to acquire complementarities and thus aligns internal resources with external environments. Augier and Teece's (2009) arguments echo Adner and Helfat's (2003) concept of dynamic managerial capabilities that top executives efficiently develop, integrate, and deploy organizational resources and competences. Thus, managerial capabilities are the critical base for a firm to develop dynamic capabilities and thus generate rents.

\section{CEO intellectual capital and rent creation}

The critical role of managerial intellectual capital in strategic decisions has been well documented (Carpenter \& Fredrickson, 2001). The impact of managerial intellectual capital on organizational performance has also been widely explored (Carpenter et al., 2001; Miller 1991; Miller \& Shamsie, 2001, Henderson, Miller, \& Hambrick, 2006; Kor, 2003). The main reason for the 
importance of intellectual capital is that the skills of top executives largely come from learning-by-doing processes (Mintzberg, 1973). These processes are highly associated with the length of experience. Although other sources of information and knowledge may confer managerial knowledge, these sources of information and knowledge may be less beneficial, because they do not experience practice. In addition, the application of managerial knowledge is highly context-specific, since each firm faces different internal and external conditions.

In addition, from the path dependency viewpoint (Penrose, 1959; Nelson \& Winter, 1982), the accumulation of knowledge is beneficial for an organization, because historical knowledge can assist a firm to better match its capabilities and environments. Particularly, managerial tasks involve dealing with complicated situations and tacit knowledge. Managerial tacit knowledge is difficult to transfer among top executives or top executives and their apprentices. Consequently, this study proposes that managerial intellectual capital is derived from managerial position tenure. Viewing the CEO tenure as a life cycle, Hambrick and Fukutomi (1991) argued that CEOs with less experience continually gain benefits from learning their internal and external environments. However, after a certain point, past experience may constrain the CEOs' cognitive ability, lead to inertia, and consequently negatively impact firm performance. Thus, Hambrick and Fukutomi (1991) suggest that the effect of CEO tenure on firm performance is an inverted-U shape. This argument has also been empirically validated (e.g., Miller \& Shamsie, 2001). Consequently, this study suggests:

Hypothesis 1a: The relationship between CEO intellectual capital and firm performance is an inverted-U shape. 


\section{CEO social capital and rent creation}

Basically, managerial social capital derives from social relationships that represent one agent's influence, control, and power on the others (Adler \& Kwon, 2002). Although social ties have been categorized as internal and external social ties, most research focuses on external social ties in the field of strategic management. Interlocking directorships of executives, which refer to executives' board positions in other firms, especially, have been well documented for the study of executives' external social ties.

Executives' interlocking directorships have several benefits for firms (see Mizruchi, 1996 for a comprehensive review). First, executives' interlocking directorships can be important channels for a firm to access external resources. Based on the resource dependence perspective (e.g., Pfeffer \& Salancik, 1978), when a firm lacks a critical resource, the firm will seek the resource from external environments. In this case, the relationship between the firm and external organizations is vital for the firm to acquire the resource. Interlocking directorships of executives can assist a firm to secure external resources, and even acquire external resources under more beneficial terms (e.g. Mizruchi \& Steams, 1994). Therefore, greater interlocking directorships may represent more channels to access critical external resources and thus be beneficial for firm performance.

In addition, interlocking directorships also play a critical role to access external information. The main function of top executives is to make strategic decisions for their firms. Top executives require related information to formulate and assess alternatives and then select a proper one from these alternatives. Under dynamic environments, information is critical for strategic decision- 
making. Thus, interlocking directorships are critical channels for top executives to access external information.

Ussem (1984) argued that top executives with greater social ties may have better abilities to scan environments and foresee future trends. In addition, sitting in other firms' board positions, top executives have the chance to acquire information regarding strategic formation and implementation of other firms. For example, Haunschild (1993) found that the acquisition behaviors of a firm are affected by its interlocking directorships with other firms. In addition, linking interlocking directorships with organizational performance, Gelatkanycz and Hambrick (1997) proposed that the alignment between information requirements and the types of executives' interlocking directorships will enhance organizational performance. Thus, this study expects:

Hypothesis 1b: The greater extent of CEO social capital, the better the firm performance.

\section{TMT social capital and rent creation}

The upper echelons of a firm include not only the CEO but also other non-CEO executives. This study expects that TMT social capital can facilitate firm performance, in addition to CEO social capital. The reason is that the more interlocking directorships that the TMT members possess, the more benefits from resources or information. These sufficient resources and information, consequently, can be the bricks for firms to outperform other firms (Gelatkanycz \& Hambrick, 1997). Therefore:

Hypothesis 2: The greater extent of TMT social capital, the greater the firm performance. 


\section{The moderating role of TMT social capital on rent creation}

In addition to viewing managerial resources individually, the interaction between CEO and TMT capabilities should also be emphasized. This interaction can be analyzed by the complementarity perspective (Amit \& Schoemaker, 1993). Amit and Schoemaker (1993), basically, argued that the value of a particular resource or capability for creating rents may depend on other resources or capabilities. Applying to the upper echelons, Carmeli and Tishler (2006) also posited that complementary managerial skills are the crucial indicators of the quality of a TMT, because these skills can help a firm to handle different managerial challenges. The concept of complementarities applies not only to resources and capabilities but also to the social capital of individuals or groups (Krishnan, Miller, \& Judge, 1997). Based on Barney's (1986) argument, different functional backgrounds and knowledge could offset each other and thus form complementary competencies. For example, in the line of acquisition research, the effects of offsetting differences have been posited to create acquisition value because functional weaknesses in one firm's TMT could be compensated by corresponding strengths in the other firm's TMT (e.g. Porter, 1987).

According to the embeddedness perspective (Granovetter, 1985), strategic actions of firms are affected and constrained by the social capital or networks of the firms because social capital or networks determine the abilities of firms to search for information and critical resources (Mizruchi, 1996). A firm contains not only CEO but also TMT social capital at its top. Consequently, TMT social capital should affect the exercise of CEO intellectual and social capital. 
Firms may benefit from greater CEO intellectual capital frequently associated with greater learning-by-doing processes. However, these capabilities may have negative impacts on firm performance. The reason is that as the CEO intellectual capital accumulated, CEOs may shape their perception, limit their information stimuli, and become less open-minded (Hambrick \& Fukutomi, 1991). Since critical strategic decisions are usually made jointly by the CEOs and their TMT members, greater TMT social capital, which broadens information channels during strategic decision-making, may lessen the negative impact of CEO intellectual capital on firm performance. The combination of CEO intellectual capital and TMT social capital can greatly benefit from both the CEO's learning-by-doing processes and information channels of the TMT, which may have sufficient external information to detect and predict industrial trends and environmental changes. Thus, this study proposes:

Hypothesis 3: TMT social capital moderates the relationship between CEO intellectual capital and firm performance in such a way that effects are more positive in the contexts of greater TMT social capital.

CEO as well as TMT social capital can be information and resource channels, and thus are beneficial to firm performance (Gelatkanycz \& Hambrick, 1997). In this study, we expect that the greatest benefits can be acquired by having both greater CEO and TMT social capital. Thus, we argue:

Hypothesis 4: TMT social capital moderates the relationship between CEO social capital and firm performance in such a way that effects are more positive in the contexts of greater TMT social capital. 


\section{MANAGERIAL RENT APPROPRIATION}

The use of managerial capabilities or resources is not without costs. However, the resource-based view of the firm only concerns the ability of a resource to create rents for a firm, but does not answer the question of how the rents are divided among internal stakeholders. Coff (1999) was among the pioneers to address this question. Integrating the bargaining power theory into the resource-based view of the firm, Coff (1999) argued that competitive advantages do not always generate rents for a firm. He further proposed that we should distinguish the rent appropriation from the rent creation when we explore organizational performance.

Coff (1999) portrayed a firm as a nexus of contracts (Jensen \& Meckling, 1976), and thus only individuals, instead of a firm, can appropriate rents. Based on the bargaining power theories such as resource dependence theory (e.g. Pfeffer \& Salancik, 1978) or Porter's (1980) five market forces framework, Coff (1999) further posited that rent-appropriation ability is based on the bargaining power of internal stakeholders. The bargaining power is stronger when stakeholders: can act as a collective union, can generate high replacement cost to the firm, have access to key information, and have low switch costs. Therefore, valuable resources or capabilities can generate rents, but the rents may be appropriated by other inside stakeholders rather than shareholders.

Focusing on managerial capabilities, Castanias and Helfat (2001) proposed that top executives both create and appropriate rents. Unlike other rent appropriation research (e.g. Chacar \& Coff, 2000) that implicitly assumes that rent appropriation among stakeholders is under given rents, Castanias and 
Helfat (2001) proposed that rents appropriated by top executives can be incentives for top executives and thus drive them to create more rents for their firms. They call this a win-win situation. Thus, managerial capabilities or capital can not only create rents for a firm but also appropriate them from the firm.

Based on the basic economic rationales, the supply of managerial capabilities or capital also determines the extent of managerial rent appropriation. Since incumbent CEOs accumulate firm-specific knowledge and build their external networks, recruiting new CEOs from external markets may not fully replace the incumbents. Firms may prefer to recruit new CEOs internally rather than externally. Therefore, internal managerial labor markets become important, and the quality of internal managerial resources becomes an issue. When TMT members possess equal or higher quality managerial capabilities, the bargaining power of CEOs' managerial capabilities will be decreased. Particularly, TMT social capital may constrain the function or use of CEO intellectual and social capital and thus curtail the rent appropriation ability of the CEO. This rationale also reflects Coff's (1999) argument that replacement cost to the firm is positively associated with the bargaining power of the inside stakeholders. In conclusion, managerial capabilities with fewer substitutes and without necessary complements appropriate greater portions of rents, and vice versa.

\section{CEO intellectual capital and rent appropriation}

Based on the economic rationales, CEO compensation should reflect their unique abilities and skills. For instance, from the loss of managerial skills viewpoint, Harris and Helfat (1997) found that external CEO successors ask for 
higher non-contingent compensation in order to compensate the loss of their prior firm-specific knowledge. Categorizing external CEO successors based on whether they are from the same industry or not, Harris and Helfat (1997) further showed that new CEOs from other industries may gain higher non-contingent compensation to compensate the loss of their industry-specific knowledge. Under the context of the sudden death of a highly paid executive, Combs and Skill (2003) also showed that stock price decreases reflecting the loss of superior human resources.

From the managerial rent appropriation aspect (Coff, 1999), CEO intellectual capital not only helps the CEO to access valuable information from organizational routines (Nelson \& Winter, 1982) but also create a nonreplaceable position in the firm. The power associated with greater CEO intellectual capital can help the CEO to bargain for and gain higher compensation. Thus, this study argues:

Hypothesis 5a: The greater extent of CEO intellectual capital, the greater the CEO total compensation.

\section{CEO social capital and rent appropriation}

Based on the value of external information and resources that CEO social capital brings into a firm, Geletkanycz, Boyd, and Finkelstein (2001) found that greater CEO external directorships lead to greater CEO total compensation. Thus, based on the logic of managerial rent appropriation (Coff, 1999), this study also expects:

Hypothesis 5b: The greater extent of CEO social capital, the greater the CEO total compensation. 


\section{TMT social capital and rent appropriation}

According to Coff's (1999) argument that bargaining power can be determined by the availability of substitutes, the value of CEO social capital may be affected by these substitutes. This study argues that TMT social capital may be strategically equivalent to CEO social capital. Thus, from the internal managerial labor market viewpoint, the influence of CEO's external social ties on higher compensation may be diminished when TMT social capital is greater. Therefore:

Hypothesis 6: The greater extent of TMT social capital, the less the CEO total compensation.

\section{The moderating role of TMT social capital on rent creation}

In addition to examining the direct effect of substitutes from TMT social capital on CEO total compensation, this study examines their indirect effects. For CEOs to fully acquire the benefits of CEO intellectual and social capital, TMT social capital is critical. Grounded by the rent appropriation aspect (Coff, 1999), this study expects that TMT social capital can weaken the CEO's abilities to appropriate rent from their firms. Therefore:

Hypothesis 7: TMT social capital moderates the relationship between CEO intellectual capital and CEO total compensation in such a way that effects are more positive in the contexts of less TMT social capital.

Hypothesis 8: TMT social capital moderates the relationship between CEO social capital and CEO total compensation in such a way that effects are more positive in the contexts of less TMT social capital. 


\section{METHODS}

\section{Sample and Data Collection}

Our sample was drawn from publicly traded firms which have sales revenue greater than $\$ 5$ million from 2003 to 2009. We obtained data from the following sources: (a) firm performance and other industry and firm-level financial data were collected from the Compustat database; (b) data on international diversification was taken from the Directory of Corporate Affiliations; (c) the CEO and TMT data were acquired from the Compustat Ехеси Сотр database; and (d) the board characteristic data was taken from the Corporate Library database. To limit the reverse causality issue, this study lagged the data of the independent and control variables by one year. Consequently, data on independent and control variables are from 2002 to 2008. After merging data from the above sources and dropping observations with missing values, our final sample contains 548 firms and 2,010 observations.

\section{Statistical Model}

We tested our proposed hypotheses by the fixed-effects regressions models. The fixed-effects regressions models are suitable for analyzing a panel data set which is the data format of this study. Additionally, this study tested interaction effects, so independent, moderating, and control variables were standardized before they entered into the regression models in order to lessen the possible issue of multicolinearity resulting from the inclusion of the moderators in the regression models. 


\section{Variables}

Below the definition and operationalization of variables is introduced.

The summary of variable definition and data sources is in Table 3.1.

Table 3.1 Variable Definition and Data Sources for Essay 2

\begin{tabular}{|c|c|c|}
\hline Variable & Description & Source \\
\hline Firm performance & $\begin{array}{l}\text { Firm performance is measured by sales growth, }\left(\text { sale }_{t}-\right. \\
\left.\text { sale }_{t-1}\right) / \text { sale }_{t-1} * 100\end{array}$ & 1 \\
\hline CEO total compensation & $\begin{array}{l}\text { ln } \sum(\text { salary }+ \text { bonus }+ \text { stock option }+ \\
\text { restrecited stock }+ \text { long }- \text { term incentive plan }+ \\
\text { other compensation })\end{array}$ & 2 \\
\hline CEO intellectual capital & $\begin{array}{l}\text { CEO intellectual capital is measured by CEO tenure, } \\
\text { length of years that a CEO serves at the CEO position }\end{array}$ & 2 \\
\hline CEO social capital & $\begin{array}{l}\text { CEO social capital is measured by CEO's interlocking } \\
\text { directorships, the number of directorships a CEO has }\end{array}$ & 3 \\
\hline TMT social capital & $\begin{array}{l}\text { TMT social capital is measured by TMT interlocking } \\
\text { directorships, summing the counts of directorships which } \\
\text { non-CEO executives have over the number of non-CEO } \\
\text { executives }\end{array}$ & 3 \\
\hline Industry profitability & $\begin{array}{l}\text { Industry } \mathrm{ROA}= \\
\sum_{i}^{n}(\text { net income } / \text { total assets }) * 1 / n * 100 \\
n: \text { the total number of firms with the same three-digits } \\
\text { SIC codes excluding the focal firm }\end{array}$ & 1 \\
\hline Product diversification & $\begin{array}{l}\text { Chatterjee and Wernerfelt's measure } \\
\text { Product diversification }=\sum_{j} d_{i h} p_{i j} \\
d_{i n} \text { : It is a distance of a business segment to the largest } \\
\text { business segment of the MNE based on SIC code; } 0 \text { if } \\
\text { they have the same four-digit SIC codes; } 1 \text { if they have } \\
\text { the same three-digit SIC code, and ect. } \\
p_{i j}: \text { sales in } j \text { business segment/total sales }\end{array}$ & 4 \\
\hline $\begin{array}{l}\text { International } \\
\text { diversification }\end{array}$ & $\begin{array}{l}\text { The number of host countries which an MNE has } \\
\text { subsidiaries located. }\end{array}$ & 5 \\
\hline R\&D intensity & $R \& D$ spending/total sales $* 100$ & 1 \\
\hline Firm profitability & $R O A=$ net income/total assets $* 100$ & 1 \\
\hline
\end{tabular}




\begin{tabular}{|l|l|l|}
\hline Firm size & The total assets of an MNE & 1 \\
\hline Board size & The number of directors on a board & 3 \\
\hline Outside director ratio & $\begin{array}{l}\text { The number of outside directors/the number of total } \\
\text { directors* } 100\end{array}$ & 3 \\
\hline CEO duality & $\begin{array}{l}\text { Dummy }=1 \text { if a CEO is also the chairperson and } 0 \\
\text { otherwise }\end{array}$ & 3 \\
\hline TMT size & A count of the total number of top officers in an MNE & 2 \\
\hline TMT average firm tenure & The mean of executives' firm tenure & 2 \\
\hline
\end{tabular}

Note: 1.Compustat database; 2. Compustat ExecuComp database; 3. Corporate Library database; 4. Compustat Segment database; 5. Directory of Corporate Affiliations database

\section{Dependent Variables}

Since this study examines managerial rent creation and appropriation, both firm performance and CEO total compensation are dependent variables of this study. This study employs sales growth, $\left(\right.$ sale $_{t}-$ sale $\left._{t-1}\right) /$ sale $_{t-1} * 100$, to measure firm performance. In addition to sales growth, other performance indicators, such as return on assets (ROA) or return on sales (ROS), have been used by prior research. This study chose sales growth rather than other indicators based on the following three reasons. First, an indicator of change is more likely to capture recent rather historical influences (Simons, Pelled, \& Smith, 1999). Second, sales change is closely linked to the fundamental rationale of social influences (Peng, 2004). More importantly, Chacar and Coff (2000) have indicated that cross performance, such as the volume of sales or sales growth, compared to residual performance, such as ROA or ROS, is a better indicator to reflect rent creation. In addition, this study uses the natural log of CEO total compensation, including CEO base salary, annual bonus, and other annual compensation, to measure the amount of rents that have been appropriated by the CEOs. 


\section{Independent variables}

CEO intellectual capital. Intellectual capital can be captured by length of experience, such as length of a managerial position or the firm service. Thus, this study uses CEO tenure to measure CEO intellectual capital. CEO tenure is defined as length of years that a CEO serves at the CEO position.

CEO social capital. Social capital, largely, is reflected by external social ties. Among various managerial external social ties, the important role of interlocking directorships has been identified (Mizruchi, 1996). Thus, this study employs a CEO's interlocking directorships as CEO social capital. The CEO's interlocking directorships are measured by counting the number of directorships a CEO has.

TMT social capital. Similar to CEO directorships, this study measures TMT social capital as TMT interlocking directorships. It was calculated by summing the counts of directorships which non-CEO executives have over the number of non-CEO executives.

\section{Control variables}

Industry profitability. Industry profitability here reflects generally the profitability of a firm's competitors in a particular industry. Average industry ROA which is the percentage of the industry net income over industry total assets is used to measure industry performance. The data on an industry are based on firms with the same three-digit standard industrial classification (SIC) code but exclude the focal firms.

Product diversification. Product diversification was controlled by this study with product diversification measured using Chatterjee and Wernerfelt's entropy measure (1991). 
International diversification. International diversification in this study is measured by the number of foreign countries in which the firms have subsidiaries located. The measure of international diversification is in line with prior research (e.g. Geringer, Beamish, \& DaCosta. 1989).

R\&D intensity. This study used R\&D intensity to be a proxy for innovation. We measured $R \& D$ intensity by the ratio of $R \& D$ spending over total sales.

Firm profitability. Return on assets (ROA), an accounting-based profitability measure, is frequently used by prior research (Carpenter et al., 2001). Thus, we used ROA, the percentage of the net income over total assets, as the indicator of firm profitability.

Firm size. Firm size can influence the ability of a firm to grow. Thus, total assets of a firm are used to measure firm size.

Board size. Board size is one of the important corporate governance variables. It was calculated by the number of directors on a board.

Outside director ratio. Outside director ratio can reflect the extent of board vigilance and thus impact firm performance. The outside director ratio was measured by the number of outside directors over the total number of directors.

CEO duality. This variable is a dummy variable. When a CEO is also the chairperson, the value of 1 was coded. Otherwise, the value of 0 was assigned.

TMT size. This study used a count of the number of top executives to measure TMT size, following past research (Carpenter et al., 2001; Simons et al., 1999). 
TMT average firm tenure. The mean of executives' firm tenure was used to measure TMT average firm tenure.

\section{RESULTS}

Table 3.2 presents means and standard deviations for all variables. Additionally, Table 3.3 shows correlations for all variables. We report the results of the fixed-effects regression analyses for firm performance in Table 3.4. In Table 3.4, model 1 is the baseline model where only control variables are included. The model is significant $(\mathrm{F}=11.79 ; \mathrm{p}<.001)$. In the baseline model, we found that R\&D intensity, firm profitability, and CEO duality have significant positive impacts on sales growth $(b=7.707, p<.001 ; b=3.168, p$ $<.001 ; \mathrm{b}=3.828, \mathrm{p}<.05$, respectively). However, Product diversification, firm size, and outside director ratio are negatively associated with sales growth $(b=$ $-4.715, \mathrm{p}<.05 ; \mathrm{b}=-10.904, \mathrm{p}<.01 ; \mathrm{b}=-6.715, \mathrm{p}<.001)$.

Table 3.2 Descriptive Statistics for Essay 2

\begin{tabular}{llrr}
\hline & & Mean & SD \\
\hline 1 & Sales growth & 7.48 & 24.37 \\
2 & CEO total compensation & 7.98 & 1.05 \\
3 & Industry Profitability & 4.14 & 9.71 \\
4 & Product diversification & 0.31 & 0.59 \\
5 & International diversification & 2.56 & 6.92 \\
6 & R\&D intensity & 8.43 & 31.94 \\
7 & Firm profitability & 3.60 & 14.86 \\
8 & Firm size & 7.60 & 36.43 \\
9 & Board size & 8.94 & 2.22 \\
10 & Outside director ratio & 68.29 & 14.90 \\
11 & CEO duality & 0.55 & 0.50 \\
12 & TMT size & 4.86 & 1.21 \\
13 & TMT average firm tenure & 11.26 & 8.73 \\
14 & CEO intellectual capital & 9.28 & 8.62 \\
15 & CEO social capital & 1.49 & 0.86 \\
16 & TMT social capital & 0.84 & 0.84 \\
\hline Note: & N=2010 & &
\end{tabular}


Table 3.3 Correlations for Essay 2

\begin{tabular}{|c|c|c|c|c|c|c|c|c|c|c|c|c|c|c|c|c|c|}
\hline & & 1 & 2 & 3 & 4 & 5 & 6 & 7 & 8 & 9 & 10 & 11 & 12 & 13 & 14 & 15 & 16 \\
\hline 1 & Sales growth & 1.00 & & & & & & & & & & & & & & & \\
\hline 2 & $\begin{array}{l}\text { CEO total } \\
\text { compensation }\end{array}$ & 0.15 & 1.00 & & & & & & & & & & & & & & \\
\hline 3 & $\begin{array}{l}\text { Industry } \\
\text { Profitability }\end{array}$ & 0.06 & 0.05 & 1.00 & & & & & & & & & & & & & \\
\hline 4 & $\begin{array}{l}\text { Product } \\
\text { diversification }\end{array}$ & -0.01 & 0.17 & -0.02 & 1.00 & & & & & & & & & & & & \\
\hline 5 & $\begin{array}{l}\text { International } \\
\text { diversification }\end{array}$ & -0.05 & 0.24 & 0.02 & 0.10 & 1.00 & & & & & & & & & & & \\
\hline 6 & R\&D intensity & 0.17 & -0.02 & 0.03 & -0.06 & 0.02 & 1.00 & & & & & & & & & & \\
\hline 7 & $\begin{array}{l}\text { Firm } \\
\text { profitability }\end{array}$ & 0.14 & 0.17 & 0.06 & 0.02 & 0.04 & -0.26 & 1.00 & & & & & & & & & \\
\hline 8 & Firm size & 0.01 & 0.21 & -0.01 & 0.22 & 0.12 & -0.03 & 0.01 & 1.00 & & & & & & & & \\
\hline 9 & Board size & 0.01 & 0.41 & 0.02 & 0.24 & 0.19 & -0.08 & 0.11 & 0.29 & 1.00 & & & & & & & \\
\hline 10 & $\begin{array}{l}\text { Outside } \\
\text { director ratio }\end{array}$ & -0.13 & 0.20 & 0.05 & 0.08 & 0.14 & 0.01 & -0.03 & 0.04 & 0.10 & 1.00 & & & & & & \\
\hline 11 & CEO duality & 0.04 & 0.10 & -0.04 & 0.08 & 0.02 & -0.10 & 0.09 & 0.09 & 0.01 & 0.10 & 1.00 & & & & & \\
\hline 12 & TMT size & -0.06 & 0.01 & -0.02 & 0.05 & 0.03 & 0.01 & -0.11 & 0.00 & 0.13 & 0.07 & -0.04 & 1.00 & & & & \\
\hline 13 & $\begin{array}{l}\text { TMT average } \\
\text { firm tenure } \\
\text { CEO }\end{array}$ & 0.04 & -0.01 & -0.04 & 0.06 & 0.04 & -0.07 & 0.09 & 0.14 & 0.14 & -0.30 & -0.07 & -0.08 & 1.00 & & & \\
\hline 14 & $\begin{array}{l}\text { intellectual } \\
\text { capital }\end{array}$ & 0.03 & -0.11 & 0.00 & -0.04 & -0.06 & 0.01 & 0.05 & -0.05 & -0.12 & -0.17 & 0.40 & -0.15 & 0.13 & 1.00 & & \\
\hline 15 & $\begin{array}{l}\text { CEO social } \\
\text { capital }\end{array}$ & 0.05 & 0.24 & 0.04 & 0.12 & 0.09 & -0.03 & 0.05 & 0.04 & 0.21 & 0.13 & 0.11 & 0.04 & -0.07 & -0.05 & 1.00 & \\
\hline 16 & $\begin{array}{l}\text { TMT social } \\
\text { capital }\end{array}$ & 0.14 & 0.16 & 0.01 & 0.08 & 0.09 & 0.02 & 0.01 & 0.10 & 0.23 & -0.21 & 0.00 & 0.08 & 0.09 & -0.02 & 0.19 & 1.00 \\
\hline
\end{tabular}

Note: $\mathrm{N}=2010$; All correlations larger than .05 in absolute value are significant at the $\mathrm{p}=.05$ level. 
Table 3.4 Results of Fixed-effects Linear Regression Analyses for Sales Growth

\begin{tabular}{|c|c|c|c|c|}
\hline Variables & Model 1 & Model 2 & Model 3 & Model 4 \\
\hline \multirow{2}{*}{ Constant } & $5.371 * * *$ & $2.939 \dagger$ & $5.597 * * *$ & $5.018 * * *$ \\
\hline & [1.137] & [1.588] & [1.139] & {$[1.131]$} \\
\hline \multirow{2}{*}{ Industry Profitability } & 0.844 & 0.823 & 0.737 & 0.783 \\
\hline & {$[0.679]$} & {$[0.679]$} & {$[0.679]$} & {$[0.675]$} \\
\hline \multirow{2}{*}{ Product diversification } & $-4.715^{*}$ & $-4.146^{*}$ & $-4.933 *$ & $-4.989^{*}$ \\
\hline & [2.061] & {$[2.072]$} & [2.059] & {$[2.047]$} \\
\hline International & -2.180 & -2.173 & -2.097 & -1.760 \\
\hline diversification & {$[1.548]$} & {$[1.548]$} & {$[1.545]$} & {$[1.539]$} \\
\hline \multirow{2}{*}{ R\&D intensity } & $7.707 * * *$ & $7.696 * * *$ & $7.778 * * *$ & $7.709 * * *$ \\
\hline & {$[1.252]$} & {$[1.250]$} & {$[1.250]$} & {$[1.242]$} \\
\hline \multirow{2}{*}{ Firm profitability } & $3.168 * * *$ & $3.152 * * *$ & $2.998 * * *$ & $3.179 * * *$ \\
\hline & {$[0.696]$} & {$[0.696]$} & {$[0.698]$} & {$[0.691]$} \\
\hline \multirow{2}{*}{ Firm size } & $-10.904 * *$ & $-10.000 * *$ & $-10.941 * *$ & $-9.942 * *$ \\
\hline & [3.690] & [3.705] & [3.683] & {$[3.668]$} \\
\hline \multirow{2}{*}{ Board size } & -1.981 & -1.736 & -1.966 & $-2.420 \dagger$ \\
\hline & [1.418] & [1.423] & [1.415] & {$[1.411]$} \\
\hline \multirow{2}{*}{ Outside director ratio } & $-6.715 * * *$ & $-6.647 * * *$ & $-6.686 * * *$ & $-5.361 * * *$ \\
\hline & {$[0.972]$} & {$[0.974]$} & {$[0.970]$} & {$[1.006]$} \\
\hline \multirow{2}{*}{ CEO duality } & $3.828 *$ & $6.431 * *$ & $3.417 \dagger$ & $4.471^{*}$ \\
\hline & {$[1.875]$} & [2.179] & [1.878] & {$[1.866]$} \\
\hline \multirow{2}{*}{ TMT size } & -0.467 & -0.544 & -0.320 & -0.473 \\
\hline & {$[0.741]$} & {$[0.742]$} & {$[0.742]$} & {$[0.735]$} \\
\hline \multirow{2}{*}{$\begin{array}{l}\text { TMT average firm } \\
\text { tenure }\end{array}$} & -0.778 & -1.054 & -0.735 & -0.538 \\
\hline & [1.318] & [1.329] & [1.315] & {$[1.309]$} \\
\hline CEO intellectual capital & & $-4.207 *$ & & \\
\hline \multirow{2}{*}{$\begin{array}{l}\text { CEO intellectual capital } \\
\text { squared }\end{array}$} & & $\begin{array}{r}{[1.70+0} \\
1.000\end{array}$ & & \\
\hline & & {$[0.682]$} & & \\
\hline CEO social capital & & & $\begin{array}{l}2.091 * \\
{[0.820]}\end{array}$ & \\
\hline TMT social capital & & & & $\begin{array}{r}3.668 * * * \\
{[0.771]}\end{array}$ \\
\hline \multirow{4}{*}{$\begin{array}{l}\text { CEO intellectual capital } \\
* \text { TMT social capital } \\
\text { CEO social capital * } \\
\text { TMT social capital }\end{array}$} & & & & \\
\hline & & & & \\
\hline & & & & \\
\hline & & & & \\
\hline No. of firms & 548 & 548 & 548 & 548 \\
\hline No. of observations & 2010 & 2010 & 2010 & 2010 \\
\hline F value & $11.79 * * *$ & $10.44 * * *$ & $11.39 * * *$ & $12.86 * * *$ \\
\hline
\end{tabular}


Table 3.4 Results of Fixed-effects Linear Regression Analyses for Sales Growth (cont.)

\begin{tabular}{|c|c|c|c|}
\hline Variables & Model 5 & Model 6 & Model 7 \\
\hline \multirow{2}{*}{ Constant } & $4.129 * *$ & $5.021 * * *$ & $4.157 * *$ \\
\hline & {$[1.251]$} & {$[1.135]$} & {$[1.252]$} \\
\hline \multirow{2}{*}{ Industry Profitability } & 0.742 & 0.763 & 0.722 \\
\hline & {$[0.673]$} & {$[0.674]$} & {$[0.672]$} \\
\hline \multirow{2}{*}{ Product diversification } & $-4.665 *$ & $-5.197 *$ & $-4.880 *$ \\
\hline & [2.049] & {$[2.042]$} & [2.044] \\
\hline International & -1.845 & -2.038 & -2.125 \\
\hline diversification & {$[1.537]$} & {$[1.541]$} & [1.539] \\
\hline \multirow{2}{*}{ R\&D intensity } & $7.688 * * *$ & $7.723 * * *$ & $7.703 * * *$ \\
\hline & [1.239] & [1.239] & {$[1.235]$} \\
\hline \multirow{2}{*}{ Firm profitability } & $3.204 * * *$ & $3.098 * * *$ & $3.123 * * *$ \\
\hline & [0.689] & {$[0.693]$} & [0.691] \\
\hline \multirow{2}{*}{ Firm size } & $-9.714 * *$ & $-10.041 * *$ & $-9.826 * *$ \\
\hline & {$[3.670]$} & [3.657] & [3.659] \\
\hline \multirow{2}{*}{ Board size } & -2.232 & $-2.384 \dagger$ & -2.202 \\
\hline & [1.413] & {$[1.406]$} & [1.408] \\
\hline \multirow{2}{*}{ Outside director ratio } & $-5.395 * * *$ & $-5.535 * * *$ & $-5.567 * * *$ \\
\hline & [1.003] & [1.005] & [1.002] \\
\hline \multirow{2}{*}{ CEO duality } & $6.187 * *$ & $4.099 *$ & $5.774 * *$ \\
\hline & [2.103] & {$[1.868]$} & [2.102] \\
\hline \multirow{2}{*}{ TMT size } & -0.379 & -0.287 & -0.193 \\
\hline & {$[0.734]$} & {$[0.736]$} & {$[0.734]$} \\
\hline \multirow{2}{*}{$\begin{array}{l}\text { TMT average firm } \\
\text { tenure }\end{array}$} & -0.646 & -0.686 & -0.784 \\
\hline & {$[1.320]$} & {$[1.307]$} & [1.317] \\
\hline \multirow{2}{*}{ CEO intellectual capital } & $-2.928 *$ & & $-2.879 *$ \\
\hline & {$[1.266]$} & & [1.263] \\
\hline \multicolumn{4}{|l|}{$\begin{array}{l}\text { CEO intellectual capital } \\
\text { squared }\end{array}$} \\
\hline \multirow{2}{*}{ CEO social capital } & & 1.268 & 1.273 \\
\hline & & {$[0.848]$} & [0.846] \\
\hline \multirow{2}{*}{ TMT social capital } & $4.640 * * *$ & $2.871 * * *$ & $3.852 * * *$ \\
\hline & {$[0.846]$} & {$[0.821]$} & [0.889] \\
\hline CEO intellectual capital & $2.829 * *$ & & $2.845 * *$ \\
\hline * TMT social capital & {$[1.058]$} & & {$[1.055]$} \\
\hline CEO social capital $*$ & & $1.054 *$ & $1.046^{*}$ \\
\hline TMT social capital & & {$[0.437]$} & [0.436] \\
\hline No. of firms & 548 & 548 & 548 \\
\hline No. of observations & 2010 & 2010 & 2010 \\
\hline F value & $11.88 * * *$ & $11.87 * * *$ & $11.14^{* * *}$ \\
\hline
\end{tabular}

Notes:

1. S.E. in square brackets.

2. $* * * \mathrm{p}<0.001 ; * * \mathrm{p}<0.01 ; * \mathrm{p}<0.05 ; \dagger \mathrm{p}<0.10 ; \mathrm{t}$ test are all two-tailed tests. 
Models 2 to 4 add three predictors, separately. Additionally, Models 5 and 6 examine the moderating effects of TMT social capital on the relationships between CEO managerial capabilities, including CEO intellectual and social capital, and sales growth. Finally, Model 7 presents the full model. Models 2 to 7 are all significant (F $=10.44, \mathrm{P}<.001 ; \mathrm{F}=11.39, \mathrm{P}<.001 ; \mathrm{F}=12.86, \mathrm{P}<.001 ; \mathrm{F}=11.88, \mathrm{P}<.001 ; \mathrm{F}=$ $11.87, \mathrm{P}<.001 ; \mathrm{F}=11.14, \mathrm{P}<.001$, respectively).

In Hypothesis 1a, we propose that the relationship between CEO intellectual capital and firm performance is an inverted-U shape. However, the coefficients for the CEO intellectual capital are negative in Model $2(b=-4.207, p<.05)$ and Model $7(b$ $=-2.879, \mathrm{p}<.05)$. The coefficient for the CEO intellectual capital squared is not significant in Model $2(\mathrm{~b}=1.000, \mathrm{p}>.10)$. Consequently, Hypothesis 1a is not supported. Hypothesis $1 \mathrm{~b}$ proposes that CEO social capital is positively associated with firm performance. Hypothesis $1 \mathrm{~b}$ receives marginal support because the coefficient for CEO social capital is significant in Model $3(\mathrm{~b}=2.091, \mathrm{p}<.05)$ but not in Model $7(b=1.273, p>.10)$. In Hypothesis 2, we expect that TMT social capital is positively associated with firm performance. This argument is supported in Model 4 $(\mathrm{b}=3.668, \mathrm{p}<.001)$ as well as in Model $7(\mathrm{~b}=3.852, \mathrm{p}<.001)$.

The moderating effects of TMT social capital on the relationships between CEO intellectual capital, CEO social capital, and firm performance are proposed in Hypotheses 3 and 4. Hypothesis 3 suggests that the positive relationship between CEO intellectual capital and firm performance will be strengthened, when TMT social capital is greater. Hypothesis 3 is supported in Model $5(b=2.829, p<.01)$ and Model $7(\mathrm{~b}=2.845, \mathrm{p}<.01)$. Figure 3.1 presents the graph. Furthermore, Hypothesis 4 proposes that TMT social capital can strengthen the positive relationship between CEO social capital and firm performance. Indeed, this argument is supported in 
Model $6(\mathrm{~b}=1.054, \mathrm{p}<.05)$ and Model $7(\mathrm{~b}=1.046, \mathrm{p}<.05)$. Figure 3.2 shows this graph.

Figure 3.1 Relationship between Sales Growth and CEO Intellectual Capital at Different Levels of TMT Social Capital

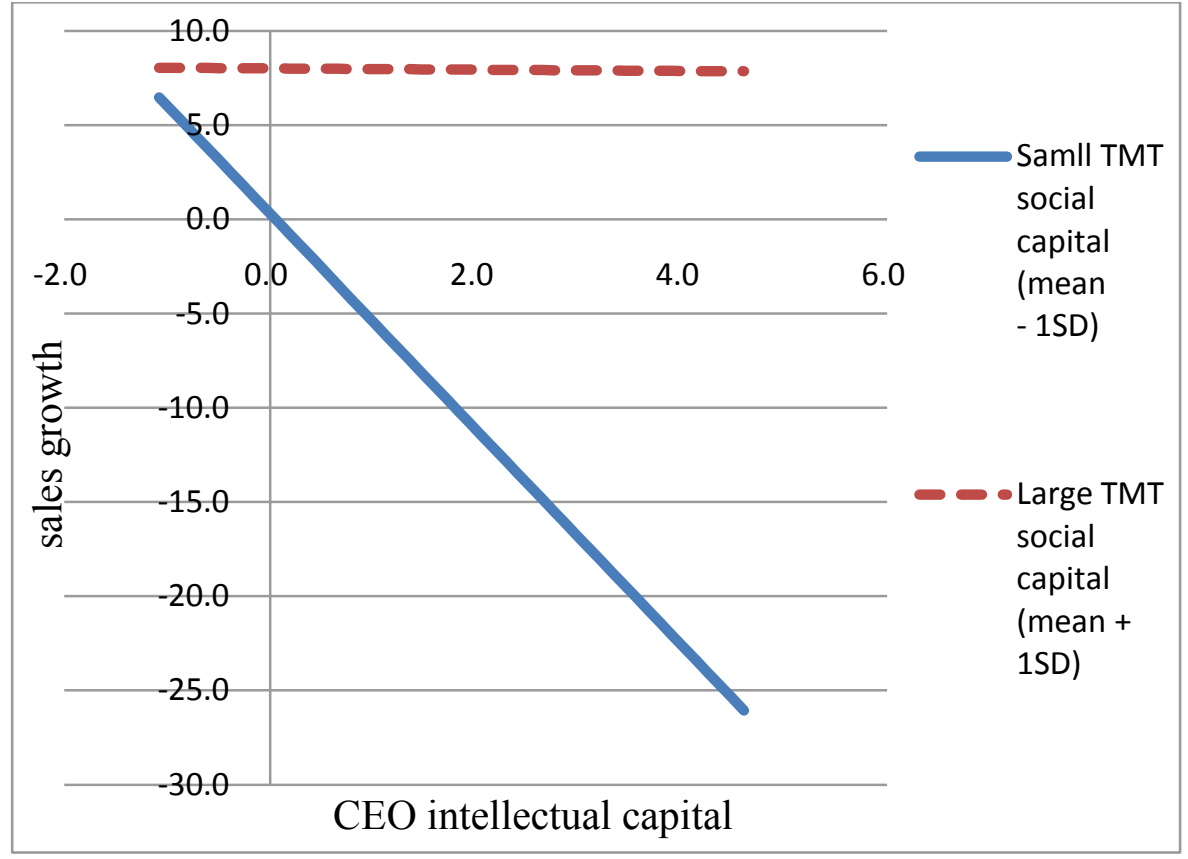

Figure 3.2 Relationship between Sales Growth and CEO Social Capital at Different Levels of TMT Social Capital

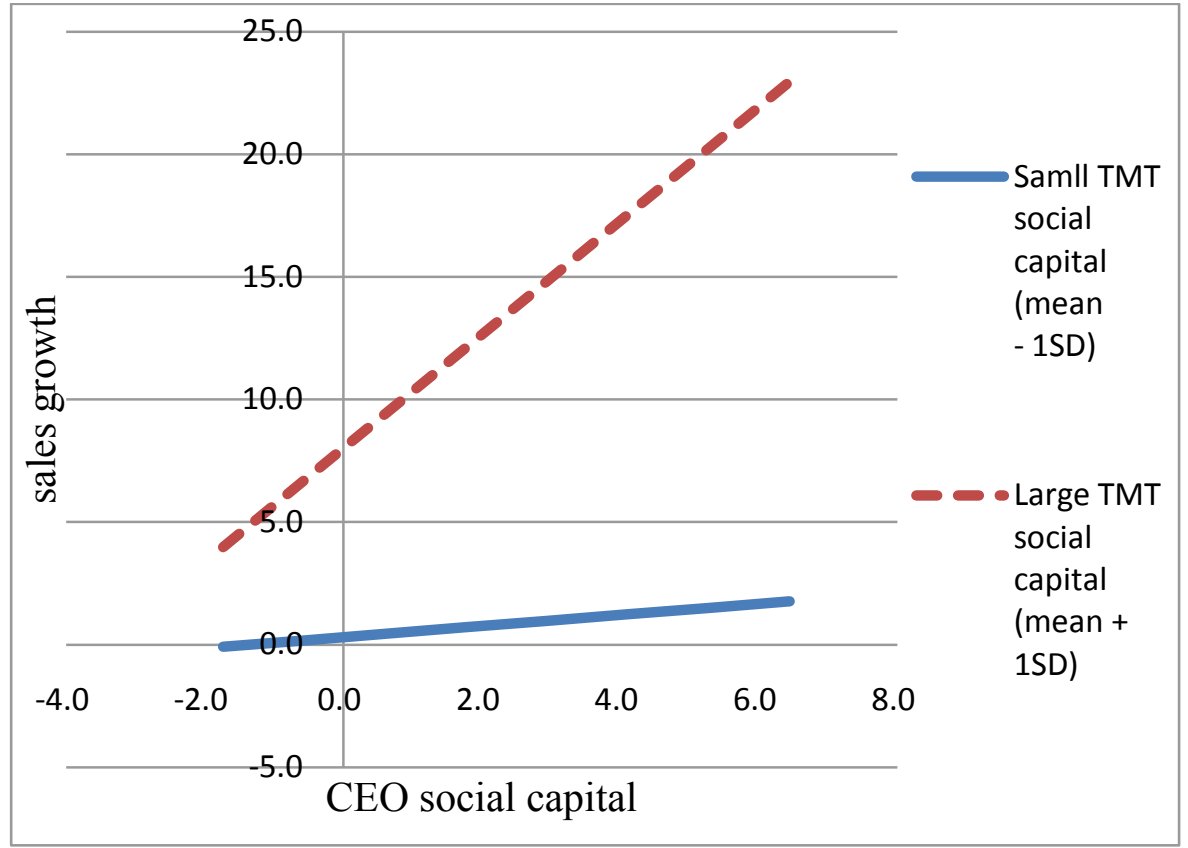


In addition to managerial rent creation in Table 3.4, Table 3.5 provides the results of fixed-effects linear regression analyses for CEO total compensation, or rent appropriation by CEOs. Model 8 of Table 3.5 is a baseline model encompassing only control variables. The results show that firm profitability and TMT average firm tenure have strong positive effects on CEO total compensation $(b=0.048, p<.01 ; b=$ $0.054, \mathrm{p}<.10$, respectively). However, TMT size has a negative impact on CEO total compensation $(b=-0.067, p<.001)$. The main effects of independent variables are included in models 9 to 11 . Models 12 and 13 add moderating factors one at a time. Finally, the full model, including all main and interaction effects, is displayed in model 14.

Hypotheses 5a and 5b predict that both CEO intellectual capital and CEO social capital are positively associated with CEO total compensation. However, these two hypotheses are not supported in Models 9, 10, and 14. Hypothesis 6 predicts that TMT social capital will be negatively associated with CEO total compensation. This hypothesis receives marginal evidence, because the coefficient for TMT social capital is significant and negative in Model $11(\mathrm{~b}=-0.040, \mathrm{p}<.05)$ but not Model $14(\mathrm{~b}=$ $0.033, \mathrm{p}>.10)$.

Hypothesis 7 predicts that interaction between CEO intellectual capital and TMT social capital will be negatively associated with CEO total compensation. From Model 12 and Model 14 of Table 3.4, the interaction coefficient (CEO intellectual capital * TMT social capital $)$ is insignificant $(b=0.041, p>.10 ; b=0.041, p>.10)$ and thus Hypothesis 7 is not supported. Hypothesis 8 expects that the interaction between CEO and TMT social capital will be negatively associated with CEO total compensation. From Model 13 and Model 14 of Table 3.4, the interaction coefficient 
(CEO social capital * TMT social capital) is not significant $(b=0.010, p>.10 ; b=$ $0.010, p>.10)$. Therefore, Hypothesis 8 is not supported.

Table 3.5 Results of Fixed-effects Linear Regression Analyses for CEO Total Compensation

\begin{tabular}{|c|c|c|c|c|}
\hline Variables & Model 8 & Model 9 & Model 10 & Model 11 \\
\hline \multirow{2}{*}{ Constant } & $7.970 * * *$ & $7.971 * * *$ & $7.970^{* * *}$ & $7.973^{* * *}$ \\
\hline & {$[0.028]$} & {$[0.031]$} & {$[0.028]$} & {$[0.028]$} \\
\hline Industry Profitability & $\begin{array}{r}0.002 \\
{[0.017]}\end{array}$ & $\begin{array}{r}0.002 \\
{[0.017]}\end{array}$ & $\begin{array}{r}0.002 \\
{[0.017]}\end{array}$ & $\begin{array}{r}0.002 \\
{[0.017]}\end{array}$ \\
\hline \multirow{2}{*}{ Product diversification } & -0.010 & -0.011 & -0.010 & -0.007 \\
\hline & {$[0.051]$} & {$[0.051]$} & {$[0.051]$} & {$[0.051]$} \\
\hline \multirow{2}{*}{$\begin{array}{l}\text { International } \\
\text { diversification }\end{array}$} & 0.052 & 0.052 & 0.052 & 0.048 \\
\hline & {$[0.038]$} & [0.038] & {$[0.038]$} & {$[0.038]$} \\
\hline \multirow{2}{*}{ R\&D intensity } & 0.050 & 0.050 & 0.050 & 0.050 \\
\hline & [0.031] & {$[0.031]$} & [0.031] & {$[0.031]$} \\
\hline \multirow{2}{*}{ Firm profitability } & $0.048^{* *}$ & $0.048 * *$ & $0.048^{* *}$ & $0.048 * *$ \\
\hline & {$[0.017]$} & [0.017] & {$[0.017]$} & {$[0.017]$} \\
\hline \multirow{2}{*}{ Firm size } & 0.098 & 0.098 & 0.098 & 0.088 \\
\hline & [0.091] & [0.092] & [0.092] & {$[0.092]$} \\
\hline \multirow{2}{*}{ Board size } & -0.003 & -0.003 & -0.003 & 0.002 \\
\hline & {$[0.035]$} & {$[0.035]$} & {$[0.035]$} & {$[0.035]$} \\
\hline \multirow{2}{*}{ Outside director ratio } & 0.025 & 0.025 & 0.025 & 0.011 \\
\hline & {$[0.024]$} & [0.024] & {$[0.024]$} & {$[0.025]$} \\
\hline \multirow{2}{*}{ CEO duality } & 0.022 & 0.020 & 0.022 & 0.015 \\
\hline & {$[0.046]$} & [0.053] & {$[0.047]$} & {$[0.047]$} \\
\hline \multirow{2}{*}{ TMT size } & $-0.067 * * *$ & $-0.067 * * *$ & $-0.067 * * *$ & $-0.067 * * *$ \\
\hline & [0.018] & {$[0.018]$} & {$[0.018]$} & {$[0.018]$} \\
\hline \multirow{2}{*}{$\begin{array}{l}\text { TMT average firm } \\
\text { tenure }\end{array}$} & $0.054 \uparrow$ & 0.054 & $0.054 \uparrow$ & 0.051 \\
\hline & {$[0.033]$} & [0.033] & {$[0.033]$} & {$[0.033]$} \\
\hline CEO intellectual capital & & $\begin{array}{r}0.002 \\
{[0.031]}\end{array}$ & & \multirow{4}{*}{$\begin{array}{l}-0.040 * \\
{[0.019]}\end{array}$} \\
\hline CEO social capital & & & $\begin{array}{r}0.001 \\
{[0.020]}\end{array}$ & \\
\hline TMT social capital & & & & \\
\hline $\begin{array}{l}\text { CEO intellectual capital } \\
\text { * TMT social capital } \\
\text { CEO social capital * } \\
\text { TMT social capital } \\
\end{array}$ & & & & \\
\hline No. of firms & 548 & 548 & 548 & 548 \\
\hline No. of observations & 2010 & 2010 & 2010 & 2010 \\
\hline$F$ value & $3.17 * * *$ & $2.90 * * *$ & $2.90^{* * *}$ & $3.26 * * *$ \\
\hline
\end{tabular}


Table 3.5 Results of Fixed-effects Linear Regression Analyses for CEO Total Compensation (cont.)

\begin{tabular}{|c|c|c|c|}
\hline Variables & Model 12 & Model 13 & Model 14 \\
\hline \multirow{2}{*}{ Constant } & $7.978 * * *$ & $7.972 * * *$ & $7.976^{* * *}$ \\
\hline & {$[0.031]$} & {$[0.028]$} & {$[0.031]$} \\
\hline \multirow{2}{*}{ Industry Profitability } & 0.002 & 0.003 & 0.003 \\
\hline & {$[0.017]$} & {$[0.017]$} & {$[0.017]$} \\
\hline \multirow{2}{*}{ Product diversification } & -0.009 & -0.008 & -0.009 \\
\hline & {$[0.051]$} & {$[0.051]$} & [0.051] \\
\hline International & 0.045 & 0.045 & 0.042 \\
\hline diversification & {$[0.038]$} & {$[0.039]$} & [0.039] \\
\hline \multirow{2}{*}{ R\&D intensity } & 0.050 & 0.049 & 0.049 \\
\hline & {$[0.031]$} & {$[0.031]$} & [0.031] \\
\hline \multirow{2}{*}{ Firm profitability } & $0.048 * *$ & $0.049 * *$ & $0.049 * *$ \\
\hline & {$[0.017]$} & {$[0.017]$} & [0.017] \\
\hline \multirow{2}{*}{ Firm size } & 0.082 & 0.087 & 0.081 \\
\hline & {$[0.092]$} & {$[0.092]$} & [0.092] \\
\hline \multirow{2}{*}{ Board size } & 0.001 & 0.002 & 0.001 \\
\hline & {$[0.035]$} & {$[0.035]$} & [0.035] \\
\hline \multirow{2}{*}{ Outside director ratio } & 0.011 & 0.009 & 0.009 \\
\hline & {$[0.025]$} & {$[0.025]$} & [0.025] \\
\hline \multirow{2}{*}{ CEO duality } & 0.009 & 0.014 & 0.007 \\
\hline & {$[0.053]$} & {$[0.047]$} & {$[0.053]$} \\
\hline \multirow{2}{*}{ TMT size } & $-0.066 * * *$ & $-0.066 * * *$ & $-0.065 * * *$ \\
\hline & [0.018] & {$[0.018]$} & [0.018] \\
\hline \multirow{2}{*}{$\begin{array}{l}\text { TMT average firm } \\
\text { tenure }\end{array}$} & $0.055 \dagger$ & 0.050 & 0.054 \\
\hline & {$[0.033]$} & {$[0.033]$} & [0.033] \\
\hline \multirow{2}{*}{ CEO intellectual capital } & -0.026 & -0.002 & -0.002 \\
\hline & {$[0.021]$} & {$[0.021]$} & [0.032] \\
\hline CEO social capital & & & $\begin{array}{r}-0.002 \\
{[0.021]}\end{array}$ \\
\hline \multirow{2}{*}{ TMT social capital } & -0.003 & $-0.046^{*}$ & -0.033 \\
\hline & {$[0.032]$} & {$[0.021]$} & [0.022] \\
\hline CEO intellectual capital & 0.041 & & 0.041 \\
\hline * TMT social capital & {$[0.026]$} & & [0.026] \\
\hline CEO social capital $*$ & & 0.010 & 0.010 \\
\hline TMT social capital & & {$[0.011]$} & [0.011] \\
\hline No. of firms & 548 & 548 & 548 \\
\hline No. of observations & 2010 & 2010 & 2010 \\
\hline F value & $2.97 * * *$ & $2.86 * * *$ & $2.65 * * *$ \\
\hline
\end{tabular}

Notes:

1. S.E. in square brackets.

2. $* * * \mathrm{p}<0.001 ; * * \mathrm{p}<0.01 ; * \mathrm{p}<0.05 ; \dagger \mathrm{p}<0.10 ; \mathrm{t}$ test are all two-tailed tests.

\section{DISCUSSION AND CONCLUSION}

The purpose of this study is to explore the rent creation and appropriation at the top of a firm. Based on the rent creation and appropriation perspectives, this study explores the direct effects of CEO intellectual capital, CEO social capital, and TMT social capital on firm performance and CEO total compensation. This study further 
examines how TMT social capital acts as a moderator in the CEO rent-creation and rent-appropriation processes. Our results indeed found that a proper fit between CEOintellectual capital and TMT social capital achieves superior firm performance. This study also demonstrated that TMT social capital can enhance the relationship between CEO social capital and firm performance. However, our results did not show any evidence to support the argument that TMT social capital can lessen CEO rentappropriation ability.

This study also has some research implications. First, this study underscores the importance of managerial intellectual capital as well as managerial social capital on firm performance. The critical role of these two constructs has been frequently proposed, (e.g., Newbert, 2007) but they are rarely examined simultaneously. In order to advance our understanding of the contributions of these two constructs on firm performance, we examine their implications on firm performance in this study. Additionally, this study contributes by showing that rent creation is jointly determined by both CEOs and their TMT members. Most past research either explores the impact of CEOs on firm performance or views a CEO as one member of the TMT (Henderson et al., 2006; Wiersema \& Bantel, 1992). However, the interactions between CEOs and their TMTs receive less attention. In order to fill this gap, this study explores the complementary role of TMT social capital on the CEO managerial capabilities to affect firm performance. Finally, this study contributes by simultaneously examining value creation and appropriation at the top of a firm.

This study is not without limitations. First, intellectual and social capital of top executives are multifaceted constructs. This study merely uses CEO tenure and interlocking directorships to be proxies of these two constructs, respectively. Thus, future research may use surveys or multiple archival data sources to gain multifaceted 
dimensions of intellectual and social capital of top executives. Secondly, this study only concerns the quantity of managerial intellectual and social capital but leaves the quality of those without considerations. Future studies may include the quality of managerial intellectual and social capital in their models. For instance, future research may examine the impacts of managerial bridging ties or managerial structural holes on firm performance. Finally, following the above suggestion, future research may view the TMT as the analysis unit of managerial social ties and investigate whether the TMT members' social ties can complement or substitute those of their CEO.

The managerial applications of this study have, at least, the following two perspectives. First, this study demonstrates the importance of TMT social capital on firm performance. In other words, firms which would like to achieve rapid growth should be equipped with TMT members possessing greater social capital or social ties. Moreover, this study emphasizes the importance of fit between the managerial capabilities of CEOs and the social capital of their TMTs. The findings of this study show that the performance implications of the managerial capabilities of CEOs depend on TMT social capital. For instance, CEOs with greater intellectual capital, or longer CEO position tenure, require matching with TMT members possessing greater social capital in order to maximize their firm performance. 


\section{REFRENCES}

Adler, P. S. \& Kwon, S. W. 2002. Social capital: Prospects for a new concept. The Academy of Management Review, 27(1): 17-40.

Adner, R. \& Helfat, C. E. 2003. Corporate effects and dynamic managerial capabilities. Strategic Management Journal, 24(10): 1011-1025.

Ahuja, G., Coff, R. W., \& Lee, P. M. 2005. Managerial foresight and attempted rent appropriation: insider trading on knowledge of imminent breakthroughs. Strategic Management Journal, 26(9): 791-808.

Amit, R. \& Schoemaker, P. J. H. 1993. Strategic assets and organizational rent. Strategic management journal, 14(1): 33-33.

Andrews, K. R. 1971. The Concept of Corporate Strategy. Homewood, IL: Irwin.

Augier, M. \& Teece, D. J. 2009. Dynamic capabilities and the role of managers in business strategy and economic performance. Organization Science, 20(2): 410421.

Barney, J. B. 1986. Strategic factor markets: expectations, luck, and business strategy. Management science, 32(10): 1231-1241.

Barney, J. B. 1991. Firm resources and sustained competitive advantage. Journal of management, 17(1): 99-120.

Blyler, M. \& Coff, R. W. 2003. Dynamic capabilities, social capital, and rent appropriation: Ties that split pies. Strategic Management Journal, 24(7): 677686.

Buyl, T., Boone, C., Hendriks, W., \& Matthyssens, P. 2011. Top management team functional diversity and firm performance: The moderating role of CEO characteristics. Journal of Management Studies, 48(1): 151-177.

Carmeli, A. \& Tishler, A. 2006. The relative importance of the top management team's managerial skills. International Journal of Manpower, 27(1): 9-36.

Carpenter, M. A. \& Fredrickson, J. W. 2001. Top management teams, global strategic posture, and the moderating role of uncertainty. Academy of Management Journal, 44(3): 533-545.

Carpenter, M. A., Sanders, G., \& Gregersen, H. B. 2001. Bundling human capital with organizational context: The impact of international assignment experience on multinational firm performance and CEO pay. The Academy of Management Journal, 44(3): 493-511.

Castanias, R. P. \& Helfat, C. E. 1991. Managerial resources and rents. Journal of Management, 17(1): 155-171. 
Castanias, R. P. \& Helfat, C. E. 2001. The managerial rents model: Theory and empirical analysis. Journal of Management, 27(6): 661-678.

Chacar, A. S. \& Coff, R. W. 2000. Deconstructing a knowledge-based advantage: rent generation, rent appropriation and performance in investment banking. In D. Hesuskel \& R. Nixon (Eds.), Winning Strategies in a Deconstructing World. New York: John Wiley.

Chatterjee, S. \& Wernerfelt, B. 1991. The link between resources and type of diversification: theory and evidence. Strategic Management Journal, 12(1): 3348.

Coff, R. W. 1999. When competitive advantage doesn't lead to performance: The resource-based view and stakeholder bargaining power. Organization Science, 10(2): 119-133.

Coff, R. W. \& Lee, P. M. 2003. Insider trading as a vehicle to appropriate rent from R\&D. Strategic Management Journal, 24(2): 183-190.

Combs, J. G. \& Skill, M. S. 2003. Managerialist and human capital explanations for key executive pay premiums: A contingency perspective. Academy of Management Journal, 46(1): 63-73.

Geletkanycz, M. A. \& Hambrick, D. C. 1997. The external ties of top executives: Implications for strategic choice and performance. Administrative Science Quarterly, 42(4): 654-681.

Geletkanycz, M. A., Boyd, B. K., \& Finkelstein, S. 2001. The strategic value of CEO external directorate networks: Implications for CEO compensation. Strategic Management Journal, 22(9): 889-898.

Geringer, J. M., Beamish, P. W., \& DaCosta, R. C. 1989. Diversification strategy and internationalization: Implications for MNE performance. Strategic Management Journal, 10(2): 109-119.

Granovetter, M. 1985. Economic action and social structure: the problem of embeddedness. American Journal of Sociology, 91(3): 481-510.

Hambrick, D. C. \& Mason, P. A. 1984. Upper echelons: The organization as a reflection of its top managers. Academy of Management Review, 9(2): 193-206.

Hambrick, D. C. \& Fukutomi, G. D. S. 1991. The seasons of a CEO's tenure. Academy of Management Review, 16(4): 719-742.

Hambrick, D. C. 2007. Upper echelons theory: An update. The Academy of Management Review, 32(2): 334-343. 
Harris, D. \& Helfat, C. 1997. Specificity of CEO human capital and compensation. Strategic Management Journal, 18(11): 895-920.

Haunschild, P. R. 1993. Interorganizational imitation: The impact of interlocks on corporate acquisition activity. Administrative science quarterly, 38(4): 564-592.

Henderson, A. D., Miller, D., \& Hambrick, D. C. 2006. How quickly do CEOs become obsolete? Industry dynamism, CEO tenure, and company performance. Strategic Management Journal, 27(5): 447-460.

Jensen, M. C. \& Meckling, W. H. 1976. Theory of the firm: Managerial behavior, agency costs and ownership structure. Journal of financial economics, 3(4): 305-360.

Klimoski, R. J. \& Koles, K. L. K. 2001. The Chief Executive Officer and Top Management Team Interface. In S. J. Zaccaro \& R. J. Klimoski (Eds.), The nature of organizational leadership: understanding the performance imperatives confronting today's leaders. San Francisco: Jossey-Bass.

Kor, Y. Y. 2003. Experience-based top management team competence and sustained growth. Organization Science, 14(6): 707-719.

Krishnan, H. A., Miller, A., \& Judge, W. Q. 1997. Diversification and top management team complementarity: is performance improved by merging similar or dissimilar teams? Strategic Management Journal, 18(5): 361-374.

Miller, D. 1991. Stale in the saddle: CEO tenure and the match between organization and environment. Management Science, 37(1): 34-52.

Miller, D. \& Shamsie, J. 2001. Learning across the life cycle: Experimentation and performance among the Hollywood studio heads. Strategic Management Journal, 22(8): 725-745.

Mintzberg, H. 1973. The nature of managerial work. New York: Harper Collins Publishers.

Mizruchi, M. S. \& Stearns, L. B. 1994. A longitudinal study of borrowing by large American corporations. Administrative Science Quarterly, 39(1): 118-140.

Mizruchi, M. S. 1996. What do interlocks do? An analysis, critique, and assessment of research on interlocking directorates. Annual Review of Sociology, 22: 271298.

Nelson, R. R. \& Winter, S. G. 1982. An evolutionary theory of economic change. Cambridge, MA: Harvard University Press.

Newbert, S. L. 2007. Empirical research on the resource based view of the firm: an assessment and suggestions for future research. Strategic Management Journal, 28(2): 121-146. 
Peng, M. W. 2004. Outside directors and firm performance during institutional transitions. Strategic Management Journal, 25(5): 453-471.

Penrose, E. 1959. The theory ofthe growth ofthe firm. New York: John Wiley \& Sons.

Pettigrew, A. M. 1992. On studying managerial elites. Strategic management journal, 13(S2): 163-182.

Pfeffer, J. \& Salancik, G. R. 1978. The external control of organizations: A resource dependence perspective. New York: Harper \& Row Publishers.

Porter, M. E. 1980. Competitive strategy: techniques for analyzing industries and competitors. New York: Free Press.

Porter, M. E. 1987. From competitive advantage to corporate strategy. Harvard business review, 5(3): 43-59.

Rumelt, R. P. 1984. Towards a strategic theory of the firm. In R. B. Lamb (Ed.), Competitive Strategic Management: 556-570. Englewood Cliffs, NJ: PrenticeHall.

Rumelt, R. P., Schendel, D., \& Teece, D. J. 1991. Strategic management and economics. Strategic management journal, 12(S2): 5-29.

Simons, T., Pelled, L. H., \& Smith, K. A. 1999. Making use of difference: Diversity, debate, and decision comprehensiveness in top management teams. The Academy of Management Journal, 42(6): 662-673.

Teece, D. J., Pisano, G., \& Shuen, A. 1997. Dynamic Capabilities and Strategic Management. Strategic Management Journal, 18(7): 509-533.

Useem, M. 1984. The inner circle: Large Corporations and Business Politics in the U.S. and U.K. New York: Oxford Univ. Press

Wernerfelt, B. 1984. A Resource-based View of the Firm. Strategic Management Journal, 5(2): 171-180.

Wiersema, M. F. \& Bantel, K. A. 1992. Top management team demography and corporate strategic change. The Academy of Management Journal, 35(1): 91121. 


\section{THE IMPACT OF A FIRM'S INSTITUTIONAL COMPLEXITY, TOP \\ MANAGEMENT TEAM TURNOVER, AND TOP MANAGEMENT \\ TEAM SIZE ON FIRM PERFORMANCE: A STRATEGIC \\ CONTINGENCY PERSPECTIVE}

\section{INTRODUCTION}

Research on the relationship between multinationality and performance has traditionally focused on the impact of international diversification by considering it as an internal resource (e.g., Hitt, Tihanyi, Miller, \& Connelly, 2006; Tallman \& Li, 1996). Recent research, however, points to the need of examining both the external and internal environment a multinational enterprise (MNE) faces to truly understand its performance (e.g., Verbeke, Li, \& Goerzen, 2009). Studies in this line of research have emphasized the importance of examining closely the external institutional environment that MNEs face, an environment that likely varies by firm and country (e.g., Chacar, Newburry, \& Vissa, 2010; Delios \& Henisz, 2003; Kostova \& Roth, 2002; Mudambi \& Navarra, 2002; Verbeke et al., 2009). Simultaneously, another stream of research has focused on the internal environment of the firm and stresses that top executives are an important determinant of organizational outcomes (e.g. Andrews, 1971; Hambrick\& Mason, 1984). Moreover, several authors observe that top management teams (TMTs) are heterogeneous across MNEs (e.g., Birkinshaw, Toulan, \& Arnold, 2001; Geringer, Beamish, \& daCosta, 1989; Ghoshal, Korine, \& Szulanski, 1994), and likely affect their performance.

This study expands current research along these directions by examining the impact on MNE performance of institutional complexity and two important top management team characteristics, namely TMT size and turnover (e.g. Amason \& Sapienza, 1997; Gordon, Stewart, Sweo, \& Luker, 2000). As firms internationalize, 
top executives have to examine and understand multiple institutional environments in the host countries where their foreign subsidiaries are located. This increases the information-processing needs and makes the decision making more challenging (e.g., Andrews, 1971; Child, 1972; Hambrick \& Mason, 1984; Porter, 1985; Sanders \& Carpenter, 1998). As a result, not only the extent of international diversification, but also the diversity in the national institutional environments facing an MNE network, which we term institutional complexity, matters.

MNEs, however, may be able to devise adequate strategies to deal with the diversity of institutional environments. They can enhance their informationprocessing capabilities (IPCs) by increasing the size of their TMT (Haleblian \& Finkelstein, 1993), and/or decreasing their TMT turnover (Dess \& Shaw, 2001; Wiersema \& Bantel, 1993). In this study we argue that when an institutional environment is complex, TMT turnover leads to the loss of accumulated managerial knowledge, while a larger TMT size can increase IPCs. Hence we propose that MNEs with greater TMT size and lower TMT turnover are likely to perform better when facing a high institutional complexity. Focusing on the latter, we zero in on the formal and informal institutions that characterize the national institutional environment, namely political and cultural institutions (e.g., Meyer, Mudambi, \&Narula, 2011; Schwens, Eiche, \&Kabst, 2011). Our empirical findings, based on 301 U.S. firms with 1,404 observations from 2002 to 2009 indeed support the arguments of this study.

The remainder of this chapter is organized as follows. In the next section we discuss a theory of MNE's information-processing demands resulting from institutional complexity and the implications of this theory for MNE performance. Then we examine the role of managerial IPCs in MNEs' operations as well as their 
implications for MNE performance. Further, the study proposes a strategic contingency theory of the impact of institutional complexity on firm performance. In the methods section we describe the empirical setting, the main variables, and the statistical model. Next, we present the results. Finally, we conclude by summarizing study's main contributions and identifying directions of future research.

\section{INFORMATION PROCESSING DEMANDS AND THE MNE}

The importance role of information-processing demands on the operations of a firm has been identified (Henderson \& Fredrickson, 1996; Madhavan \& Prescott, 1995). In order to enhance the likelihood of making accurate strategic-decisions, firms require gathering, transferring, communicating, analyzing, and storing information effectively (Galbraith, 1973). Compared to domestic firms, MNEs are a complex form of organization (Ghoshal \& Nohria, 1989). This complex form leads to demanding greater extents of information-processing on top executives of these MNEs (Egelhoff, 1991). This information-processing results from multiple sources of international operations. For instance, the top management of MNEs demands to take dissimilarities in social values or national cultures (Kogut \& Singh, 1988) and in political systems (Henisz, 2000) between their home and host countries into considerations, when making strategic decisions. Additionally, simultaneously encountering a variety of dissimilarities in national cultures or political systems adds another level of information-processing demands.

The relationship between information-processing demands and MNEs has been addressed repeatedly in the international business literature directly or indirectly. According to the logic of organizational economics, MNEs encounter new and unfamiliar environments in foreign countries, and they need ownership advantage, such as superior technological capabilities, to equip themselves to compete with 
indigenous firms (Hymer, 1976). Echoing Hymer's argument about the costs of doing business in foreign countries, Zaheer (1995) labels this situation as the liability of foreignness. In a similar vein, internalization process theory proposes that the trajectory of foreign market expansion is constrained by the international environmental complexity (Johnanson \& Vahlne, 1977 \& 1990). In other words, this theory predicts the process of international expansion of a firm is an incremental or step-by-step process, because the firm needs to accumulate knowledge on operating in foreign countries in order to make its resource commitment without bearing high risk and uncertainty.

\section{INSTITUTIONAL ENVIROMENT AND COMPLEXITY}

In international settings, the importance of national institutions has been recognized by international business research (e.g., Kostova, Roth, \& Dacin, 2008). These institutional environments are critical because they constrain and shape the interactions among economic agents (North, 1990). North (1990) thus called them the 'rules of the game'. Additionally, countries vary in terms of their institutional arrangements and for an MNE operating in various countries, different strategies are required to be able to adapt or meet the needs of local institutions (Scott, 1995). For instance, studies investigating the entry mode have found that similarities between home and host countries, not only in terms of political institutions but also national cultures, are important for the choice of international entry mode (Kogut \& Singh, 1988; Delios \& Henisz, 2000). MNEs concurrently operating in varieties of institutional dissimilarities between the home and host countries may use an array of entry modes. Consequently, complexity results from managing these various forms of entries. When considering MNEs facing various institutional environments, Kostova 
and Zaheer (1999) also argue that creating and maintaining organizational legitimacy is a challenging task for MNEs.

\section{INSTITUTIONAL COMPLEXITY AND FIRM PERFORMANCE}

In line with the information-processing view of the MNE (Egelhoff, 1991) and research on institutions in international business (e.g., Kostova, 1999), this study examines the impacts of institutional complexity, TMT turnover, and TMT size on firm performance. On the one hand, greater MNE's institutional complexity leads to greater learned knowledge as well as information-processing demands and, consequently, may have both positive and negative impacts on firm performance. On the other hand, lower TMT turnover and larger TMT size can mitigate the negative effects and enhance an MNE's managerial IPCs that are critical for coping with MNE's institutional complexity. Therefore, this study proposes that the linkage between institutional complexity and firm performance is moderated by TMT turnover and TMT size.

Although the critical role of information-processing demands deriving from institutional complexity has been identified, the performance implications of institutional complexity are inconclusive (Goerzen \& Beamish, 2003; Zahra, Ireland, \& Hitt, 2000). On the benefits' side of institutional complexity, being immersed in a variety of institutional environments assist the MNEs to access various sources of knowledge in foreign countries. This lens of institutional complexity is based on the organizational learning perspective (Huber 1991; Katila \& Ahuja, 2002; Lane, Salk, \& Lyles, 2001; Levitt \& March, 1988). Learning from idiosyncratic institutional environments can assist MNEs to accumulate knowledge and build their competitive advantages (Barney, 1991; Grant, 1996) as well as increase their survival chances (Mohrman \& Von Glinow, 1990). Moreover, the acquired knowledge can assist 
MNEs to not only exploit their existing capabilities but also create and explore new capabilities. Zahra et al. (2000) also found that operating in diverse international environments leads to greater knowledge breadth and depth and consequently is associated with superior performance and greater organizational growth.

Operating in dispersed institutional environments may also pose threats for MNEs. When MNEs enter into countries that are institutionally distant, there will be only a negligible overlap with the existing knowledge and, as Cohen and Levinthal (1990) point out, firms learn from their local experience only if the new knowledge overlaps with or is related to their existing knowledge (Cohen and Levinthal, 1990). Similarly, Barkema and Drogendijk (2007) argue that some overlap between the company's knowledge base and the knowledge required for operating in the new cultural bloc is needed for the company to be able to interpret the local experience, assimilate it, and put it to commercial ends. When an MNE faces similar institutional environments, the MNE can improve and refine their existing knowledge (Barkema \& Drogendijk, 2007) which leads to semi-automatic reproduction of their existing routines (Zollo \& Winter, 2002; Ahuja \& Lampert, 2001), and to the application of existing concepts and objects, rather than to the development of new ones (Cohen \& Levinthal, 1990). However, greater institutional complexity means that established competencies cannot be directly applied. Consequently, either internal costs, which translate existing capabilities or develop new capabilities for local needs, or external costs, which result from the lack of fit between the MNE's global standard and local expectations, occur (Westney, 1993). Goerzen and Beamish (2003) indeed found a negative relationship between diversified institutional environments faced by MNEs and MNE performance. 
Within the research on institutions and MNEs, political institutions and culture in particular have drawn a lot of attention and their role has been largely documented (e.g., Delios \& Henisz, 2003; Kogut\& Singh, 1988; Meyer, et al., 2011). In line with previous research, this study proposes that political and cultural institutions are two key dimensions of institutional complexity. The impacts or constraints of political institutions, formal institutions, on MNEs have been widely discussed (Boddewyn, 1988; Delios \& Henisz, 2003; Henisz, 2000). For instance, Henisz and Williamson (1999) demonstrated that in the context of a domestic market the choice to have joint venture partners is determined purely by a contractual hazard consideration which is based on transaction cost economics. However, in the context of international markets contractual and political hazards need to be jointly considered, when the strategic decisions on international entry mode choices are made. Additionally, the impact of political hazards on contractual hazards should be considered (Henisz, 2000).

The presence of checks and balances in a host country reduces the likelihood for an MNE to be exploited opportunistically by the host government. On the other side, the MNEs can adjust their entry mode strategies or develop other mechanisms to deal with the risk of expropriation. However, the skills and routines developed in dealing with a host government are highly idiosyncratic and hard to transfer to another country if the countries differ substantially in terms of their political constraints profiles. An MNE operating in different countries and exposed to a variety of political institutions bears a greater adjustment costs in order to meet local needs. However, MNEs can benefit from accumulating information and knowledge on handling a variety of institutional environments and accessing knowledge and resources embedded in the diversified political institutions. Since political complexity 
of a firm has both positive and negative impacts on firm performance, a pair of hypotheses is proposed:

Hypothesis 1a: A firm's political complexity will be positively associated with firm performance.

Hypothesis 1b: A firm's political complexity will be negatively associated with firm performance.

MNEs operating in multiple countries face various national cultures. These national cultural institutions, or informal institutions, are also critical for MNEs operating in a variety of societal value systems (Hofstede, 1984; House, 2004). Past research has documented that not only conflicts (Von Glinow, Shapiro, \& Brett, 2004) but also difficulties in transferring knowledge (Kogut \& Singh, 1988) will occur when larger cultural differences are presented. Consequently, we can expect that an MNE simultaneously operating in various societal value systems will be challenged by these difficulties. A firm's cultural complexity also increases extra costs, such as coordinating or communication costs, and information-processing demands at the headquarters. However, firms can learn from operating in a broad array of national cultures and thus build better capabilities to service the local needs (Bartlett \& \& Ghoshal. 1989). Thus, since there are pros and cons on operating in a variety of national cultural environments, another pair of hypotheses is suggested:

Hypothesis 2a: A firm's cultural complexity will be positively associated with firm performance.

Hypothesis 2b: A firm's cultural complexity will be negatively associated with firm performance. 


\section{TMT, INSTITUTIONAL COMPLEXITY, AND FIRM PERFORMANCE}

Although the assumption of classic economics states that economic actors are rational and possess perfect information, firms or their executives have been frequently viewed as actors with bounded rationality (Williamson, 1975; Jenson \& Meckling, 1976). Consequently, managerial IPCs are critical for firms. The TMT of a firm is the "dominant coalition" of individuals in charge of the strategic decisionmaking of firms (e.g. Cyert \& March, 1963). Identifying environmental opportunities and threats, organizational strengths and constraints, as well as related information, TMTs formulate and implement strategic choices (Child, 1972). This stream of research emphasizes the importance of top management on strategic decision-making (e.g., Andrews, 1971; Child, 1972). Thus, the IPCs of top management could affect strategic behaviors of MNEs, because these capabilities will determine or constrain the amount of information needed for decision-making as well as the spectrum of strategic choices.

The focus of upper echelons theory is on the cognitive operation of top managers. A TMT receives potential stimuli from inside and outside of firms through the cognitive bases of the members within the TMT. Taking a sequential view Hambrick and Mason (1984) posited a sequentially perceptual process that forms and limits the perception of a TMT regarding particular strategic choices. Following March and Simon's (1958) argument, the upper echelons theory proposed that decision makers of a TMT exert their cognitive base to make strategic decisions. This cognitive base of a TMT is built by the knowledge of the objects, the knowledge of alternatives, and the knowledge of consequences associated with alternatives. Since it is difficult for a TMT to possess perfect knowledge, the knowledge of a TMT tends to be constrained by its cognitive base. Thus, the cognitive base of a TMT will reflect 
the information processing capabilities of the TMT including its capabilities to gather and process information and to generate the number and variety of alternatives.

From the IPCs aspect, TMT turnover and TMT size are two important dimensions of TMT composition, (Haleblian \& Finkestein, 1993; Sanders \& Carpenter, 1998; Tushman \& Rosenkopf, 1996; Virany, Tushman, \& Romanelli, 1992; Wiersema \& Bantel, 1993). TMT turnover is critical but prior research largely views it as a mechanism of adaptation to better handle a turbulent environment (Wiersema \& Bantel, 1993). This line of research neglects that a higher TMT turnover may curtail the abilities of TMT members to build and accumulate greater knowledge over time, and thus hamper the IPCs of a firm to deal with a complex environment faced by the firm. On the other hand, TMT size is associated with the extent of IPCs of the TMT (Haleblian \& Finkelstein, 1993). For example, a greater extent of international diversification demands a greater size of TMT (Sanders \& Carpenter, 1998). Consequently, TMT size is positively associated with MNE performance (Carpenter, Sanders, \& Gregersen, 2001). In the following, this study thus proposes that TMT turnover and TMT size can reflect managerial IPCs of MNEs.

In addition to examining the impact of institutional complexity on firm performance, this study further focuses on the interaction effects between institutional complexity, TMT turnover, and TMT size, based on a strategic contingency aspect (Harrigan, 1983; Venkatraman, 1989). In other words, firm performance is jointly determined by the interactions of the institutional complexity, reflecting external information-processing demands, and TMT turnover as well as TMT size, representing internal managerial IPCs. The strategic contingency perspective has been largely used to explore the impact of interaction between top executives and external environments on organizational performance (Haleblian\& Finkelstein, 1993; 
Karaevli, 2007). The theoretical argument in this study is that the fit between the information-processing demands, which are triggered by intuitional complexity, and managerial IPCs can lead to superior firm performance. However, in the unmatched situations, this interaction is associated with inferior firm performance. Below, this study hypothesizes the impacts of interactions between institutional complexity, TMT turnover, and TMT size on firm performance.

\section{Information-Processing Capabilities and TMT Turnover}

Although a firm may benefit from a higher TMT turnover in the circumstance which existing repertoires need to be replaced by new ones (Tushman \& Rosenkopf, 1996; Virany et al., 1992; Wiersema \& Bantel, 1993), the benefits may not be exercised in MNEs which require TMT members to build and accumulate greater knowledge over time in order to better apply existing repertoires into a variety of institutional environments. According to human capital theory (Becker, 1964), top executives accumulate firm-specific human capital embodied in their firms. The changes of top executives result in losing human capital, and then firm-specific human capital accumulations at the top of a firm are depleted. Although firms can recruit new top executives to replace these vacant positions, new executives need time to acquire and accumulate firm-specific knowledge. Thus, new executives' performance may not be as good as experienced executives that are retained in firms. Thus, a higher TMT turnover may have negative impacts on managerial IPCs.

Additionally, greater TMT turnover erodes managerial IPCs not only by depleting managerial firm-specific knowledge but also by losing the social structure and fabric of an organization (Dess \& Shaw, 2001). In such cases, the loss of key network members can have serious damages in an organization's social fabric and even erode its social capital all together (Leana \& Van Buren, 1999). Particularly, 
turnover among executives who occupy central network positions could be more damaging to managerial IPCs than turnover among executives who occupy less central network positions. Thus, from the social capital perspective, greater TMT turnover may lead to inferior managerial IPCs.

\section{A Firm's Institutional Complexity and TMT turnover}

Operating in diversified institutional environments has several potential benefits (Zahra et al, 2000). These benefits include that learned experience or knowledge in an institutional environment can be modified and transferred into other settings (Levitt \& March, 1988). Additionally, firms can benefit from leveraging resources in foreign countries simultaneously when the firms operate in multiple countries (Dunning, 1997). The breadth and depth of organizational knowledge can also be escalated, when a firm is immersed in multiple institutional environments (Zahra et al, 2000). The potential advantages for operating in a variety of institutional environments are the ability to exploit firms' existing resources and capabilities as well as the opportunity to explore new resources and capabilities (Dunning \& Lundan, 2008). Consequently, institutional complexity may not only assist a firm's survival (Mohrman \& Von Glinow, 1990) but also create its competitive advantages (Barney, 1991).

To fully acquire these potential benefits, firms demand a greater extent of managerial IPCs. The situation of managing institutional complexity differs from a firm facing dynamic or turbulent environments in which the firm needs to renew or reset its knowledge and capabilities. When environmental turbulence occurs, the firm may benefit from having larger TMT turnover which gains more new managerial knowledge and abilities by bringing in new executives from the external (Virany et al., 1992). Rather, facing institutional complexity, it is needed to develop dynamic 
capabilities (Teece, Pisano, \& Shuen, 1997) or absorptive capability (Cohen and Levinthal, 1990; Zahra and George, 2002) which is based on path-dependence. Furthermore, the managerial capabilities to effectively manage the repeated exercise of routines are emphasized. In other words, when encountering the situation of institutional complexity, the managerial capabilities to retain knowledge from path dependence become critical. Greater TMT turnover may lose a firm's accumulated knowledge from path dependence and weaken its managerial capabilities to manage this knowledge. Consequently, this study expects:

Hypothesis 3: TMT turnover moderates the relationship between political complexity and firm performance in such a way that effects are more positive in the contexts of a lower TMT turnover.

Hypothesis 4: TMT turnover moderates the relationship between cultural complexity and firm performance in such a way that effects are more positive in the contexts of a lower TMT turnover.

\section{Information-Processing Capabilities and TMT Size}

In addition to TMT turnover, TMT size is related to the use of information by the team. As the number of members in a TMT increases, more differentiation in perspective (Dearborn \& Simon, 1958) and specialization of skills and diversity of opinion (Bales \& Borgatta, 1955) are expected. Hambrick and D’Aveni (1992: 1449) noted that "the resources available on a team result from how many people are on it." Based on the argument that information is a kind of resource, it also can be held that a large TMT can acquire more information, compared to a small one. Furthermore, Srivastava and Lee (2005: 467) stated "a larger TMT size could also indicate more extensive inter-firm network of the top management." In other words, larger networking derived from greater TMT size may gain more information and thus 
possess better capabilities to predict environmental situations and judge the quality of potential alternatives. Consequently, large team size has been proposed to possess better problem-solving capabilities. Compared to a small TMT, a large TMT with more top executives may also have greater IPCs. Generally, larger teams may tend to possess more sufficient resources and capabilities for solving team tasks (e.g. Hill, 1982). These superior problem-solving capabilities derive from increasing the amount and variety of information, critical judgments, alternatives, and perspectives (e.g. Harrison, 1975).

\section{A Firm's Institutional Complexity and TMT Size}

Although the benefits of more cohesive and harmonious small teams have been proposed (e.g. Shaw, 1981), these benefits tend to occur in easier tasks (Hare, 1952), rather than in complex decision-making. As a result, increasing team size may benefit from increasing problem-solving capabilities. Facing institutional complexity, top executives demand a larger amount of information to process. Thus, a greater TMT size reflects larger managerial IPCs for the firm. In other words, in the situation of institutional complexity, the benefits associated with a greater TMT size is likely to be fully exercised. Therefore, this study argues:

Hypothesis 5: TMT size moderates the relationship between political complexity and firm performance in such a way that effects are more positive in the contexts of a larger TMT size.

Hypothesis 6: TMT size moderates the relationship between cultural complexity and firm performance in such a way that effects are more positive in the contexts of a larger TMT size. 


\section{METHODS}

\section{Sample and Data Sources}

Our sample is based on archival data from 2002 to 2009. To limit the reverse causality issue, this study lagged the data of the independent and control variables by one year. Consequently, data on independent and control variables are from 2001 to 2008. We obtained data from the following sources: (a) firm performance and other industry- and firm-level financial data were collected from the Compustat database; (b) data on host countries which the foreign subsidiaries of firms are located were taken from the Directory of Corporate Affiliations (DCA); (c) the TMT data were acquired from the Compustat ExecuComp database and 10-K; (d) the board characteristic data from the Corporate Library database; and (d) Henisz's Political Constraint Index (POLCON) dataset and Global Project on national cultures were the data sources for political and cultural institutions, respectively. The initial sample for the study was the DCA data, which contains information on the foreign subsidiaries of US firms. Since the purpose of this study is to examine institutional complexity on firm performance, we kept firms which had a ticker symbol in DCA. Our initial sample hence included 6,911 observations on 1,836 public firms. Additionally, since our focus is on institutional complexity, we only include firms with subsidiaries operating in three or more foreign countries. Based on this criterion, 3,752 observations were dropped. Since firms with one year observation cannot capture unobservable time variation, 196 firms with one year observations in the DCA were deleted. Then, we left 2,963 observations on 635 firms. After merging data from other sources and dropping observations with missing values, our final sample contains 301 firms and 1,404 observations. 


\section{Statistical Model}

This study used a panel data set so the fixed-effects regression models were used to test the hypotheses. The fixed-effects regression models as well as randomeffects regression models can be used for analyzing panel data. This study followed commonly used statistical procedure and ran the Hausman specification test to determine which models should be used. The results of the Hausman specification test suggest that the fixed-effects regression models are more suitable for this study. Therefore, the fixed-effects regression models were selected. Since this study included interaction terms in the regression models, this study entered standardized predictors into the regression models in order to reduce the potential issue of multicolinearity caused by including interactions in the regression models.

\section{Variables}

Below the definition and operationalization of variables is introduced. The summary of variable definition and data sources is in Table 4.1.

Table 4.1 Variable Definition and Data Sources for Essay 3

\begin{tabular}{|c|c|c|}
\hline Variable & Description & Source \\
\hline Firm performance & $R O A=$ net income/total assets $* 100$ & 1 \\
\hline Political complexity & $\begin{array}{l}\text { Political complexity = coefficient of variation on the } \\
\text { POLCON distance }(\mathrm{pccv}) \text {; } \\
\text { Calculation steps: } \\
\text { Step 1: Calculation for Political distance } \text { P }_{j}= \\
\text { abs }\left(\text { POLCON } N_{j}-\text { POLCON }_{u s}\right) ; j \text { : a host country which a } \\
\text { foreign subsidiary of an } \mathrm{MNE} \text { locates } \\
\text { Step 2: pccv }=\left(\text { sd } \text { of Political distance }_{j} / \text { mean of }\right. \\
\left.\text { Political distance }{ }_{j}\right)\end{array}$ & 2 \\
\hline
\end{tabular}




\begin{tabular}{|c|c|c|}
\hline Cultural complexity & $\begin{array}{l}\text { Cultural complexity }=\text { coefficient of variation on the } \\
\text { GLOBAL PROJECT's cultural distance (cccv); } \\
\text { Calculation steps: } \\
\text { Step 1: Calculation for } \text { Cultural distance }_{i}= \\
\left.\sum_{i=1}^{9}\left(I_{i j}-I_{i u s}\right)^{2} / V_{i}\right) * 1 / 9 ; j: \text { a host country; } i \text { a } \\
\text { dimension of culture; } V \text { : variance of a cultural } \\
\text { dimension; This measure is similar to Kogut and Singh's } \\
(1988) \text { indicator of cultural distance } \\
\text { Step 2: cccv }=\left(\text { sd of Cultural distance }{ }_{i} / \text { mean of }\right. \\
\left.\text { Cultural distance } e_{i}\right)\end{array}$ & 3 \\
\hline TMT turnover & $\begin{array}{l}\text { The number of changes of top executives/ } \\
\text { the total number of top executives } t_{t-1} * 100\end{array}$ & 4 \\
\hline TMT size & A count of the total number of top officers in an MNE & 4 \\
\hline Industry performance & $\begin{array}{l}\text { Industry } \mathrm{ROA}= \\
\sum_{i}^{n}(\text { net } \text { income } / \text { total assets }) * 1 / n * 100 \\
n: \text { the total number of firms with the same three-digits } \\
\text { SIC codes excluding the focal firm }\end{array}$ & 1 \\
\hline Product diversification & $\begin{array}{l}\text { Chatterjee and Wernerfelt's measure } \\
\text { Product diversification }=\sum_{j} d_{i h} p_{i j} \\
d_{i h}: \text { It is a distance of a business segment to the largest } \\
\text { business segment of the MNE based on SIC code; } 0 \text { if } \\
\text { they have the same four-digit SIC codes; } 1 \text { if they have } \\
\text { the same three-digit SIC code, and ect. } \\
p_{i j}: \text { sales in } j \text { business segment/total sales }\end{array}$ & 5 \\
\hline International diversification & $\begin{array}{l}\text { The number of host countries which an MNE has } \\
\text { subsidiaries located. }\end{array}$ & 6 \\
\hline R\&D intensity & R\&D spending/total sales $* 100$ & 1 \\
\hline Firm size & The total assets of an MNE & 1 \\
\hline Board size & The number of directors on a board & 7 \\
\hline Outside director ratio & $\begin{array}{l}\text { The number of outside directors/the number of total } \\
\text { directors } * 100\end{array}$ & 7 \\
\hline TMT average firm tenure & The mean of executives' firm tenure & 4 \\
\hline
\end{tabular}




\begin{tabular}{|l|l|l|}
\hline TMT average age & The mean of executives' age & 4 \\
\hline $\begin{array}{l}\text { TMT firm tenure } \\
\text { heterogeneity }\end{array}$ & $\begin{array}{l}\text { Following Wiersema and Bantel's (1992) suggestion, } \\
\text { TMT firm tenure heterogeneity was measured by the } \\
\text { coefficient of variation of executives' firm tenure }\end{array}$ & 4 \\
\hline TMT age heterogeneity & The coefficient of variation of executives' age & 4 \\
\hline
\end{tabular}

Note: 1. Compustat database; 2. Henisz's Political Constraint Index (POLCON) dataset; 3. House's

Global Project; 4. Compustat ExecuComp database; 5. Compustat Segment database; 6. Directory of

Corporate Affiliations database; 7. Corporate Library database

\section{Dependent Variable}

Firm performance. Return on assets (ROA), an accounting-based performance measure, is frequently used by prior research (e.g., Virany, et al., 1992). Thus, we used ROA, the percentage of the net income over total assets, as the indicator of firm performance in this study. Additionally, return on sales (ROS), the percentage of the net income over total sales, was used for robustness checks.

\section{Independent and control variables}

Firm's political complexity. Henisz's political constraints (POLCON) were employed to capture the political institutions of a nation. The POLCON indicator measures the extent to which the structure of political institutions affects or constrains the choice of public policy (Henisz, 2000). Past research has widely used this indicator (Delios \& Henisz, 2003; Henisz, 2000). For calculating institutional complexity, two steps were needed. First, the data on the entire institutional distances between the U.S. home country and all host countries in which subsidiaries of a firm are located was needed. Each political distance was measured by the absolute value of the difference between the U.S.'s and a host country's scores on the POLCON indicator. Second, a complex measure needs to be created. Here, MNE's political complexity was measured by the coefficient of variation, which is commonly used for measuring the dispersion of a continuous variable (Wiersema \& Bantel, 1992). It was 
calculated by the standard deviation of all political distances between the U.S., the home country of an MNE, and foreign countries, which the subsidiaries of the MNE are located, over the mean of these distances.

Firm's cultural complexity. The cultural institutions of a nation were gathered from the GLOBAL project. House's (2004) GLOBAL project on national cultures contains nine national cultural dimensions: assertiveness, institutional collectivism, in-group collectivism, future orientation, gender egalitarianism, humane orientation, performance orientation, power distance, and uncertainty avoidance. Since cultural institutions include nine dimensions, this study used Kogut and Singh's (1988) formula to construct a distance index. This formula generates a composite index of the GLOBAL project's nine cultural dimensions. The absolute value of the difference between the U.S.'s and a host country's scores was used to measure each cultural distance. Finally, cultural complexity was measured by the coefficient of variation of an MNE's cultural distances.

TMT turnover.TMT in this study is defined as the number of top executives listed on a firm's annual proxy, DEF14A SEC form, similar to prior research which use the list of top executives on the filings as the definition of TMT (Carpenter, Pollock, \& Leary, 2003; Gordon et al., 2000). TMT turnover is a ratio measure. It was calculated by the number of changes of top executives over the total number of top executives in last year, in line with past research (Virany, et al., 1992).

TMT size. This study used a count of the number of top executives to measure TMT size, following past research (Carpenter et al., 2001; Hambrick \& D'Aveni, 1992; Hoffman, Lheureux, \& Lamont, 1997; Simons, Pelled, \& Smith, 1999).

Industry profitability. Industry profitability here reflects generally the profitability of a firm's competitors in a particular industry. Average industry ROA 
which is the percentage of the industry net income over industry total assets is used to measure industry performance. The data on an industry are based on firms with the same three-digit standard industrial classification (SIC) code but exclude the focal firms.

Product diversification. The spectrum of product portfolio can determine the profitability of a firm (Palepu, 1985). Therefore, product diversification was controlled by this study with product diversification measured using Chatterjee and Wernerfelt's entropy measure (1991).

International diversification. Prior research has documented that international diversification can impact firm performance (e.g., Geringer et al., 1989). International diversification in this study is measured by the number of foreign countries in which the firms have subsidiaries located. The measure of international diversification is in line with prior research (e.g. Geringer et al. 1989).

R\&D intensity. Innovation is critical to build a firm's competitive advantages, and thus impacts firm performance (e.g., Hitt, Hoskisson, \& Kim, 1997). This study used $R \& D$ intensity to be a proxy for innovation. We measured R\&D intensity by the ratio of $R \& D$ spending over total sales.

Firm size. Firm size is widely accepted to influence the MNE performance (e.g., Hitt et al., 1997). Thus, total assets of a firm are used to measure firm size and are controlled by this study.

Board size. Board size is one of the important corporate governance variables. It was calculated by the number of directors on a board.

Outside director ratio. Outside director ratio can reflect the extent of board vigilance and thus impact firm performance. The outside director ratio was measured by the number of outside directors over the total number of directors. 
TMT average firm tenure. The mean of executives' firm tenure was used to measure TMT average firm tenure.

TMT average age. TMT average age was calculated by the mean of executives' age.

TMT firm tenure heterogeneity. It represents the shared common firm experiences. Following Wiersema and Bantel's (1992) suggestion, TMT firm tenure heterogeneity was measured by the coefficient of variation of executives' firm tenure which is calculated by the standard deviation of the TMT's firm tenure over its mean.

TMT age heterogeneity. Similar to the calculation of TMT firm tenure heterogeneity, the coefficient of variation of executives' age is used to measure TMT age heterogeneity.

\section{RESULTS}

Table 4.2 presents means, standard deviations, and Table 4.3 demonstrates correlations for all variables. We report the results of the fixed-effects regression analyses for firm performance in Table 4.4. In Table 4.4, Model 1 is the baseline model where only control variables are included. The model is significant $(\mathrm{F}=4.01 ; \mathrm{p}$ $<.001)$. Five control variables: industry profitability, R\&D intensity, outside director ratio, TMT firm tenure heterogeneity, and TMT age heterogeneity, are significant in Model 1. In the baseline model, interestingly, we found that neither product diversification nor international diversification has a significant effect on firm performance. These results may once again document that the effects of product diversification or international diversification on firm performance are more complicated than a linear relationship.

In the baseline model, we found that industry profitability is positively associated with firm performance $(b=1.774, p<.001)$ in the baseline model. It 
indicates that firm performance will increase 1.774 units when industry profitability increases 1 unit. Additionally, in the baseline model, we found that R\&D intensity has a negative impact on firm performance, the coefficient of $R \& D$ intensity $(b=-$ $1.612, \mathrm{p}<.10$ ), which is in congruence with prior findings (Bouquet, Morrison, \& Birkinshaw, 2009; Lu \& Beamish, 2004). Furthermore, the baseline model showed that outside director ratio, TMT firm tenure heterogeneity, and TMT age heterogeneity have negative impacts on firm performance $(b=-1.289, p<.05 ; b=$ $1.612, \mathrm{p}<.01 ; \mathrm{b}=-1.266, \mathrm{p}<.10$, respectively).

Models 2 and 3 add two predictors, separately. Additionally, Model 4 to 7 add the interaction between political complexity and TMT turnover, the interaction between cultural complexity and TMT turnover, the interaction between political complexity and TMT size, and the interaction between cultural complexity and TMT size, respectively. Finally, Model 8 presents the full model. Models 2 to 8 are all significant $(\mathrm{F}=3.74, \mathrm{P}<.001 ; \mathrm{F}=3.76, \mathrm{P}<.001 ; \mathrm{F}=4.64, \mathrm{P}<.001 ; \mathrm{F}=3.81, \mathrm{P}<$ $.001 ; \mathrm{F}=4.09, \mathrm{P}<.001 ; \mathrm{F}=3.77, \mathrm{P}<.001 ; \mathrm{F}=6.01, \mathrm{P}<.001)$.

Although this study does not hypothesize the impacts of TMT turnover and TMT size on firm performance, we can observe these relationships through our Models. In the full model, Model 8, we did not find any relationship between TMT turnover and firm performance, because the coefficient for the TMT turnover is insignificant in Model $8(b=.517, p>.01)$. However, the full model showed that TMT size negatively impacts firm performance $(b=-.880, p<.10)$. This result may contradict the predictions in most prior research, but Certo, Lester, Dalton, and Dalton (2006) did not find a consistent association between TMT size and organizational performance in their meta-analysis. 
Since a firm's political complexity has positive as well as negative impacts on firm performance, a pair of hypotheses is proposed in hypotheses 1a and 1b. However, the coefficients for the political complexity are insignificant in Model $2(b=.686, p$ $>.10)$ as well as Model $8(\mathrm{~b}=.212, \mathrm{p}>.10)$. Thus, neither Hypothesis 1a nor Hypothesis $1 \mathrm{~b}$ is supported. Similarly, another pair of hypotheses proposed in Hypothesis 2a and Hypothesis $2 \mathrm{~b}$ to examine the relationship between a firm's cultural complexity and firm performance. The coefficient for the cultural complexity is insignificant in Model $3(b=-1.094, p>.10)$ but significant in Model $8(b=-1.809$, $\mathrm{p}<.10$ ). Consequently, Hypothesis $2 \mathrm{~b}$ rather than Hypothesis $2 \mathrm{a}$ receives a marginal support.

In Hypothesis3, we propose that TMT turnover moderates the relationship between political complexity and firm performance in such a way that effects are more positive in the contexts of a lower TMT turnover. This hypothesis is supported in both Model $4(\mathrm{~b}=-1.527, \mathrm{p}<.001)$ and Model $8(\mathrm{~b}=-2.159, \mathrm{p}<.001)$. Figure 4.1 shows this graph. Similarly, Hypothesis 4 argues that TMT turnover moderates the relationship between cultural complexity and firm performance in such a way that effects are more positive in the contexts of a lower TMT turnover. The coefficients for the interaction between a firm's cultural complexity and TMT turnover are significant in Model $5(\mathrm{~b}=-1.014, \mathrm{p}<.01)$ and Model $8(\mathrm{~b}=-1.342, \mathrm{p}<.001)$. Therefore, Hypothesis 4 is supported. Figure 4.2 demonstrates the graph.

Hypothesis 5 suggests that TMT size moderates the relationship between political complexity and firm performance in such a way that effects are more positive in the contexts of a larger TMT size. The coefficients for the interaction between a firm's political complexity and TMT size are significant in Model $6(b=1.360, p$ $<.01)$ and Model $8(\mathrm{~b}=2.239, \mathrm{p}<.001)$. Consequently, the results show that 
Hypothesis 5 is supported. Figure 4.3 presents the graph. In Hypothesis 6, we expect that TMT size moderates the relationship between cultural complexity and firm performance in such a way that effects are more positive in the contexts of a larger TMT size. The results also support Hypothesis 6, because the coefficients for the interaction between a firm's cultural complexity and TMT size are significant in Model $7(\mathrm{~b}=.947, \mathrm{p}<.01)$ and Model $8(\mathrm{~b}=1.212, \mathrm{p}<.01)$. Figure 4.4 shows the graph.

Table 4.2 Descriptive Statistics for Essay 3

\begin{tabular}{|c|c|c|c|}
\hline & Variables & Mean & $S D$ \\
\hline 1 & Firm performance & 4.49 & 13.69 \\
\hline 2 & $\begin{array}{l}\text { Industry } \\
\text { Profitability }\end{array}$ & 3.91 & 7.12 \\
\hline 3 & $\begin{array}{l}\text { Product } \\
\text { diversification }\end{array}$ & 0.44 & 0.64 \\
\hline 4 & $\begin{array}{l}\text { International } \\
\text { diversification }\end{array}$ & 11.47 & 10.64 \\
\hline 5 & $\mathrm{R} \& \mathrm{D}$ intensity & 7.91 & 8.95 \\
\hline 6 & Firm size & 14.95 & 98.34 \\
\hline 7 & Board size & 9.34 & 2.29 \\
\hline 8 & $\begin{array}{l}\text { Outside director } \\
\text { ratio }\end{array}$ & 74.11 & 14.05 \\
\hline 9 & $\begin{array}{l}\text { TMT average firm } \\
\text { tenure }\end{array}$ & 7.95 & 4.38 \\
\hline 10 & TMT average age & 51.99 & 3.98 \\
\hline 11 & $\begin{array}{l}\text { TMT firm tenure } \\
\text { heterogeneity }\end{array}$ & 0.71 & 0.32 \\
\hline 12 & $\begin{array}{l}\text { TMT age } \\
\text { heterogeneity }\end{array}$ & 0.12 & 0.05 \\
\hline 13 & TMT turnover & 18.93 & 17.82 \\
\hline 14 & TMT size & 5.88 & 1.18 \\
\hline 15 & Political complexity & 0.97 & 0.39 \\
\hline 16 & Cultural complexity & 0.56 & 0.19 \\
\hline
\end{tabular}


Table 4.3 Correlations for Essay 3

\begin{tabular}{|c|c|c|c|c|c|c|c|c|c|c|c|c|c|c|c|c|c|}
\hline & Variables & 1 & 2 & 3 & 4 & 5 & 6 & 7 & 8 & 9 & 10 & 11 & 12 & 13 & 14 & 15 & 16 \\
\hline 1 & Firm performance & 1.00 & & & & & & & & & & & & & & & \\
\hline 2 & $\begin{array}{l}\text { Industry } \\
\text { Profitability }\end{array}$ & 0.17 & 1.00 & & & & & & & & & & & & & & \\
\hline 3 & $\begin{array}{l}\text { Product } \\
\text { diversification }\end{array}$ & 0.02 & -0.01 & 1.00 & & & & & & & & & & & & & \\
\hline 4 & $\begin{array}{l}\text { International } \\
\text { diversification }\end{array}$ & 0.11 & 0.08 & 0.18 & 1.00 & & & & & & & & & & & & \\
\hline 5 & $\mathrm{R} \& \mathrm{D}$ intensity & -0.17 & -0.03 & -0.26 & 0.09 & 1.00 & & & & & & & & & & & \\
\hline 6 & Firm size & -0.01 & -0.02 & 0.06 & 0.09 & -0.05 & 1.00 & & & & & & & & & & \\
\hline 7 & Board size & 0.10 & 0.11 & 0.22 & 0.29 & -0.16 & 0.22 & 1.00 & & & & & & & & & \\
\hline 8 & $\begin{array}{l}\text { Outside director } \\
\text { ratio }\end{array}$ & -0.02 & 0.00 & 0.11 & 0.16 & -0.03 & 0.01 & 0.16 & 1.00 & & & & & & & & \\
\hline 9 & $\begin{array}{l}\text { TMT average firm } \\
\text { tenure }\end{array}$ & 0.07 & 0.00 & 0.06 & 0.03 & -0.05 & -0.02 & 0.15 & -0.21 & 1.00 & & & & & & & \\
\hline 10 & TMT average age & 0.02 & 0.07 & 0.15 & 0.10 & -0.13 & 0.06 & 0.17 & -0.08 & 0.37 & 1.00 & & & & & & \\
\hline 11 & $\begin{array}{l}\text { TMT firm tenure } \\
\text { heterogeneity }\end{array}$ & -0.06 & -0.02 & 0.03 & 0.16 & 0.03 & 0.09 & 0.18 & -0.03 & 0.09 & 0.12 & 1.00 & & & & & \\
\hline 12 & $\begin{array}{l}\text { TMT age } \\
\text { heterogeneity }\end{array}$ & -0.08 & -0.12 & -0.11 & -0.17 & 0.07 & 0.02 & -0.14 & -0.20 & 0.08 & 0.03 & 0.09 & 1.00 & & & & \\
\hline 13 & TMT turnover & -0.07 & 0.03 & -0.02 & 0.05 & 0.09 & 0.11 & 0.03 & 0.01 & -0.12 & 0.03 & 0.13 & 0.02 & 1.00 & & & \\
\hline 14 & TMT size & -0.13 & -0.14 & 0.02 & 0.06 & 0.03 & 0.13 & 0.13 & 0.06 & -0.19 & -0.07 & 0.29 & 0.14 & 0.34 & 1.00 & & \\
\hline 15 & Political complexity & 0.04 & 0.06 & 0.05 & 0.23 & -0.09 & 0.02 & 0.12 & 0.04 & -0.03 & 0.03 & 0.08 & 0.01 & 0.04 & 0.01 & 1.00 & \\
\hline 16 & Cultural complexity & 0.10 & -0.03 & 0.05 & -0.11 & -0.13 & 0.01 & 0.04 & -0.08 & 0.03 & 0.05 & 0.00 & -0.06 & -0.01 & 0.03 & -0.03 & 1.00 \\
\hline
\end{tabular}


Table 4.4 Results of Fixed-effects Linear Regression Analyses for ROA

\begin{tabular}{|c|c|c|c|c|}
\hline Variables & Model 1 & Model 2 & Model 3 & Model 4 \\
\hline \multirow{2}{*}{ Constant } & $4.492 * * *$ & $4.492 * * *$ & $4.492 * * *$ & $4.551 * * *$ \\
\hline & {$[0.309]$} & {$[0.309]$} & [0.309] & {$[0.307]$} \\
\hline \multirow{2}{*}{ Industry Profitability } & $1.774 * * *$ & $1.743 * * *$ & $1.781 * * *$ & $1.736 * * *$ \\
\hline & [0.401] & {$[0.402]$} & {$[0.401]$} & [0.399] \\
\hline \multirow{2}{*}{ Product diversification } & 0.902 & 0.904 & 0.871 & 0.953 \\
\hline & {$[1.071]$} & {$[1.071]$} & {$[1.071]$} & {$[1.063]$} \\
\hline \multirow{2}{*}{ Internationalization } & -0.823 & -0.955 & -1.028 & -1.009 \\
\hline & [1.199] & [1.209] & {$[1.217]$} & {$[1.200]$} \\
\hline \multirow{2}{*}{ R\&D intensity } & $-1.612 \dagger$ & $-1.598 \dagger$ & $-1.638 \dagger$ & $-1.577 \dagger$ \\
\hline & {$[0.960]$} & {$[0.960]$} & [0.960] & {$[0.952]$} \\
\hline \multirow{2}{*}{ Firm size } & -3.690 & -3.859 & -3.771 & -3.382 \\
\hline & {$[2.986]$} & {$[2.992]$} & [2.987] & [2.972] \\
\hline \multirow{2}{*}{ Board size } & -1.178 & -1.240 & -1.334 & -1.183 \\
\hline & {$[0.867]$} & {$[0.870]$} & [0.881] & {$[0.863]$} \\
\hline \multirow{2}{*}{ Outside director ratio } & $-1.289 *$ & $-1.278 *$ & $-1.282 *$ & $-1.276^{*}$ \\
\hline & {$[0.602]$} & {$[0.602]$} & {$[0.602]$} & {$[0.598]$} \\
\hline \multirow{2}{*}{ TMT average firm tenure } & -0.443 & -0.444 & -0.361 & -0.551 \\
\hline & [0.979] & {$[0.979]$} & [0.983] & [0.972] \\
\hline \multirow{2}{*}{ TMT average age } & -0.355 & -0.357 & -0.374 & -0.446 \\
\hline & {$[0.885]$} & {$[0.885]$} & [0.885] & {$[0.887]$} \\
\hline \multirow{2}{*}{$\begin{array}{l}\text { TMT firm tenure } \\
\text { heterogeneity }\end{array}$} & $-1.612 * *$ & $-1.633 * *$ & $-1.606 * *$ & $-1.725 * *$ \\
\hline & {$[0.584]$} & {$[0.584]$} & {$[0.584]$} & {$[0.582]$} \\
\hline \multirow{2}{*}{ TMT age heterogeneity } & $-1.266 \dagger$ & $-1.296 \dagger$ & $-1.244 \dagger$ & $-1.288 *$ \\
\hline & {$[0.648]$} & {$[0.649]$} & [0.649] & {$[0.645]$} \\
\hline \multirow{2}{*}{ TMT turnover } & & & & 0.259 \\
\hline & & & & {$[0.370]$} \\
\hline \multicolumn{5}{|l|}{ TMT size } \\
\hline \multirow{2}{*}{ Political complexity } & & 0.686 & & 0.362 \\
\hline & & {$[0.784]$} & & {$[0.782]$} \\
\hline Cultural complexity & & & $\begin{array}{r}-1.094 \\
{[1.114]}\end{array}$ & \\
\hline \multirow{2}{*}{$\begin{array}{l}\text { Political complexity * TMT } \\
\text { turnover }\end{array}$} & & & & $-1.527 * * *$ \\
\hline & & & & {$[0.350]$} \\
\hline \multirow{2}{*}{\multicolumn{5}{|c|}{$\begin{array}{l}\text { Cultural complexity } * \text { TMT } \\
\text { turnover }\end{array}$}} \\
\hline & & & & \\
\hline \multicolumn{5}{|l|}{$\begin{array}{l}\text { Political complexity } * \text { TMT } \\
\text { size }\end{array}$} \\
\hline \multirow{2}{*}{\multicolumn{5}{|c|}{$\begin{array}{l}\text { Cultural complexity } * \text { TMT } \\
\text { size }\end{array}$}} \\
\hline & & & & \\
\hline No. of firms & 301 & 301 & 301 & 301 \\
\hline No. of observations & 1404 & 1404 & 1404 & 1404 \\
\hline F value & $4.01 * * *$ & $3.74 * * *$ & $3.76 * * *$ & $4.64 * * *$ \\
\hline
\end{tabular}


Table 4.4 Results of Fixed-effects Linear Regression Analyses for ROA (cont.)

\begin{tabular}{|c|c|c|c|c|}
\hline Variables & Model 5 & Model 6 & Model 7 & Model 8 \\
\hline \multirow{2}{*}{ Constant } & $4.477 * * *$ & $4.472 * * *$ & $4.462 * * *$ & $4.486 * * *$ \\
\hline & {$[0.309]$} & {$[0.308]$} & [0.309] & [0.302] \\
\hline \multirow{2}{*}{ Industry Profitability } & $1.767 * * *$ & $1.554 * * *$ & $1.713 * * *$ & $1.453 * * *$ \\
\hline & [0.400] & {$[0.405]$} & {$[0.403]$} & [0.397] \\
\hline \multirow{2}{*}{ Product diversification } & 0.918 & 0.907 & 0.999 & 1.125 \\
\hline & [1.069] & {$[1.066]$} & {$[1.070]$} & {$[1.045]$} \\
\hline \multirow{2}{*}{ Internationalization } & -1.026 & -1.096 & -1.017 & -1.415 \\
\hline & {$[1.215]$} & [1.204] & [1.215] & [1.198] \\
\hline \multirow{2}{*}{ R\&D intensity } & $-1.730 \dagger$ & -1.484 & -1.294 & -1.267 \\
\hline & {$[0.958]$} & {$[0.958]$} & [0.966] & [0.943] \\
\hline \multirow{2}{*}{ Firm size } & -3.532 & -3.954 & -3.756 & -2.849 \\
\hline & [2.982] & {$[2.980]$} & [2.982] & [2.925] \\
\hline \multirow{2}{*}{ Board size } & -1.404 & -1.112 & -1.191 & -1.180 \\
\hline & {$[0.880]$} & {$[0.867]$} & {$[0.881]$} & [0.864] \\
\hline \multirow{2}{*}{ Outside director ratio } & $-1.284 *$ & $-1.298^{*}$ & $-1.346^{*}$ & $-1.318^{*}$ \\
\hline & {$[0.600]$} & {$[0.600]$} & {$[0.601]$} & {$[0.587]$} \\
\hline \multirow{2}{*}{ TMT average firm tenure } & -0.352 & -0.639 & -0.524 & -0.633 \\
\hline & {$[0.980]$} & {$[0.985]$} & [0.991] & [0.969] \\
\hline \multirow{2}{*}{ TMT average age } & -0.423 & -0.322 & -0.311 & -0.523 \\
\hline & {$[0.892]$} & {$[0.882]$} & [0.884] & [0.871] \\
\hline \multirow{2}{*}{$\begin{array}{l}\text { TMT firm tenure } \\
\text { heterogeneity }\end{array}$} & $-1.601 * *$ & $-1.386^{*}$ & $-1.309^{*}$ & $-1.476^{*}$ \\
\hline & {$[0.584]$} & {$[0.617]$} & {$[0.617]$} & {$[0.605]$} \\
\hline \multirow{2}{*}{ TMT age heterogeneity } & $-1.137 \dagger$ & -1.051 & $-1.154 \dagger$ & -0.852 \\
\hline & {$[0.650]$} & {$[0.656]$} & {$[0.656]$} & [0.643] \\
\hline \multirow{2}{*}{ TMT turnover } & 0.184 & & & 0.517 \\
\hline & {$[0.373]$} & & & {$[0.393]$} \\
\hline \multirow{2}{*}{ TMT size } & & -0.719 & -0.744 & $-0.880 \dagger$ \\
\hline & & {$[0.481]$} & [0.481] & [0.508] \\
\hline \multirow{2}{*}{ Political complexity } & & 0.688 & & 0.212 \\
\hline & & {$[0.782]$} & & {$[0.770]$} \\
\hline \multirow{2}{*}{ Cultural complexity } & -1.208 & & -1.202 & $-1.809 \dagger$ \\
\hline & [1.114] & & [1.113] & [1.094] \\
\hline \multirow{2}{*}{$\begin{array}{l}\text { Political complexity * TMT } \\
\text { turnover }\end{array}$} & & & & $-2.159 * * *$ \\
\hline & & & & {$[0.371]$} \\
\hline \multirow{2}{*}{$\begin{array}{l}\text { Cultural complexity } * \text { TMT } \\
\text { turnover }\end{array}$} & $-1.014 * *$ & & & $-1.342 * * *$ \\
\hline & {$[0.366]$} & & & {$[0.384]$} \\
\hline \multirow{2}{*}{$\begin{array}{l}\text { Political complexity } * \text { TMT } \\
\text { size }\end{array}$} & & $1.360 * *$ & & $2.239 * * *$ \\
\hline & & {$[0.438]$} & & {$[0.465]$} \\
\hline \multirow{2}{*}{$\begin{array}{l}\text { Cultural complexity * TMT } \\
\text { size }\end{array}$} & & & $0.947 * *$ & $1.212 * *$ \\
\hline & & & {$[0.421]$} & {$[0.443]$} \\
\hline No. of firms & 301 & 301 & 301 & 301 \\
\hline No. of observations & 1404 & 1404 & 1404 & 1404 \\
\hline$F$ value & $3.81 * * *$ & $4.09 * * *$ & $3.77 * * *$ & $6.01 * * *$ \\
\hline
\end{tabular}

Notes: 1. S.E. in square brackets. 2 . ${ }^{* * *} \mathrm{p}<0.001 ; * * \mathrm{p}<0.01 ; * \mathrm{p}<0.05 ; \dagger \mathrm{p}<0.10 ; \mathrm{t}$ test are all twotailed tests. 
Figure 4.1 Relationship between Firm Performance and Political Complexity at Different TMT Turnover Levels

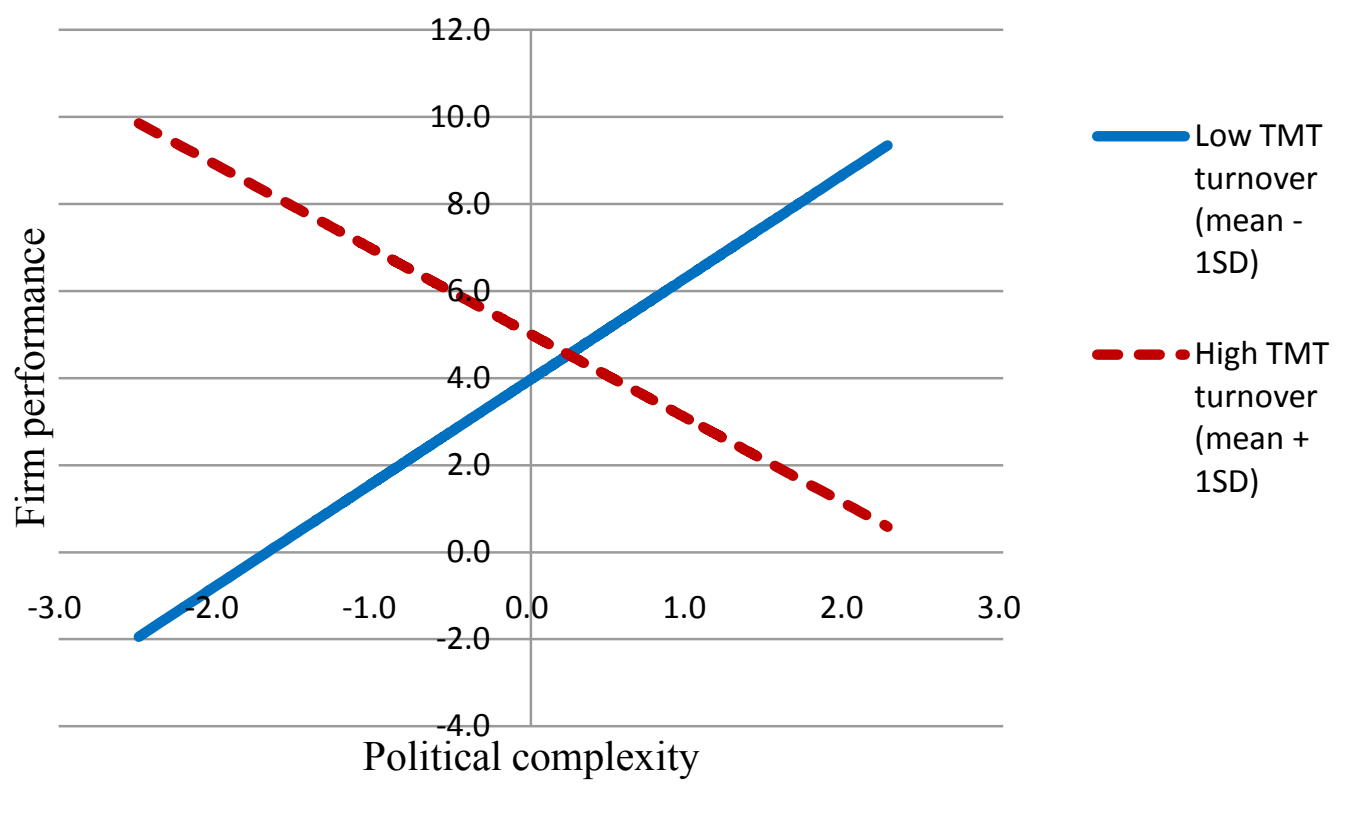

Figure 4.2 Relationship between Firm Performance and Cultural Complexity at Different TMT Turnover Levels

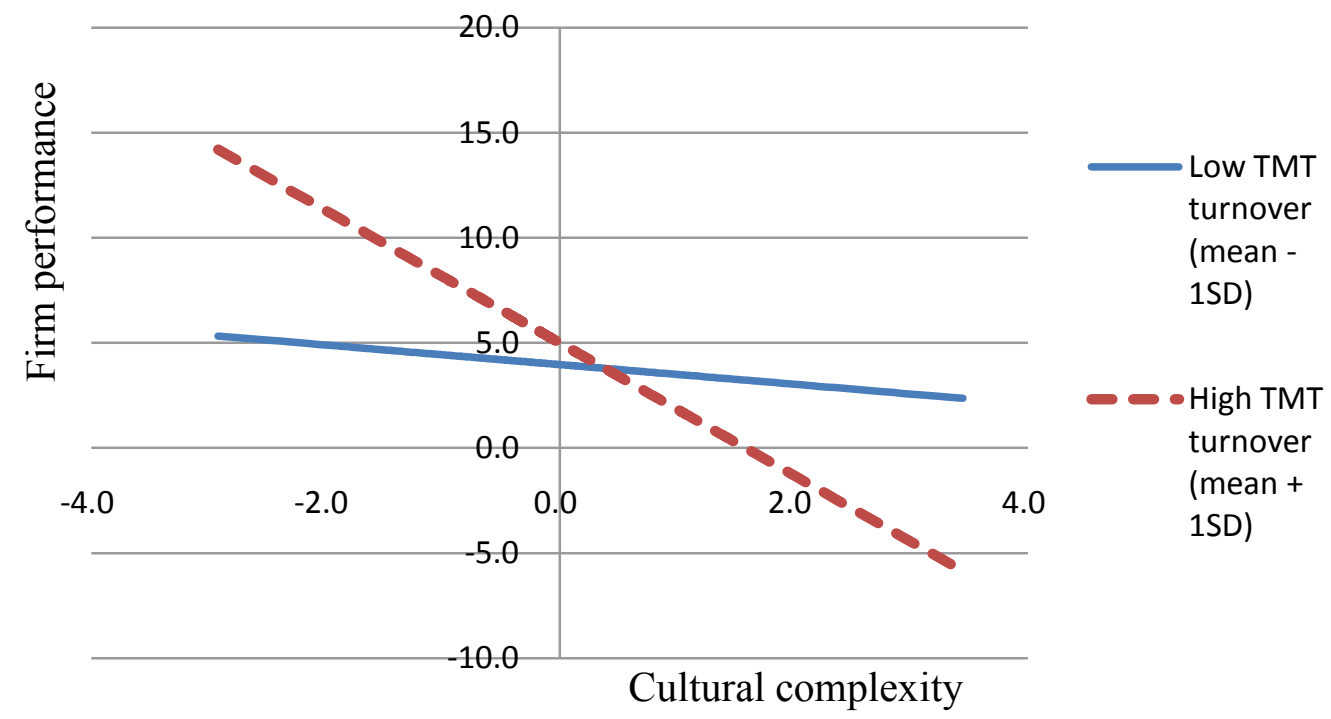


Figure 4.3 Relationship between Firm Performance and Political Complexity at Different TMT Size Levels

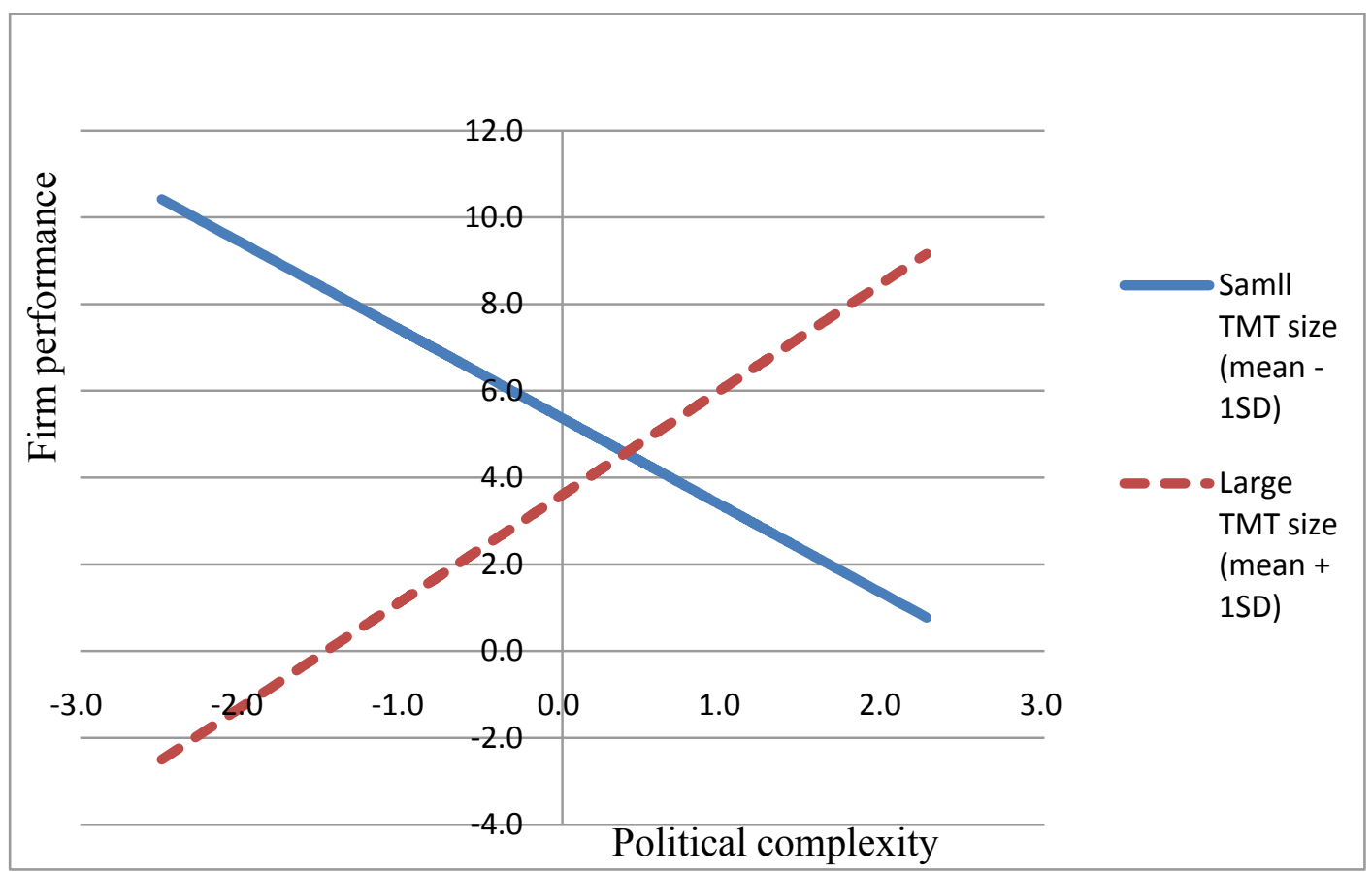

Figure 4.4 Relationship between Firm Performance and Cultural Complexity at Different TMT Size Levels

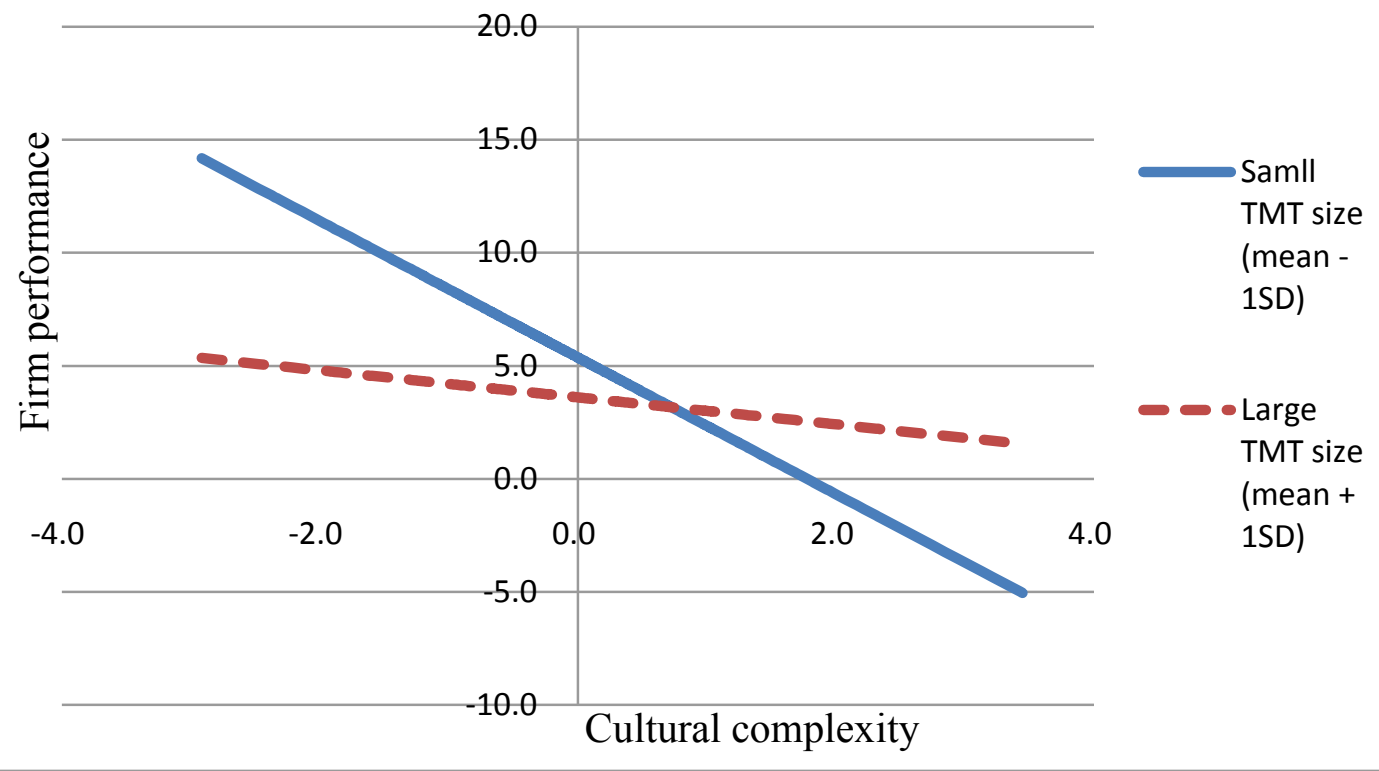




\section{Robustness Check}

This study uses return on sales (ROS) as the dependent variable for robustness checks. Correspondently, industry profitability, a control variable, is measured by average industry ROS based on the three-digit SIC code but exclude the focal firms. The results of the fixed-effects regression analyses for ROS show in Table 4.5. Model 9 is as the baseline model. Models 10 and 11 add the predictors individually. Then, Models 12 to 15 enter the four interaction terms, proposed by this study, separately. Finally, Model 16 is the full model. Congruent with the results in Table 4.4, in addition to Hypothesis 1a, 1b, 2a, Hypothesis $2 \mathrm{~b}$ and Hypotheses 3 to 6 proposed by this study are supported in Table 4.5.

\section{DISCUSSION AND CONCLUSION}

Much national research emphasizes the importance of environments on performance (e.g., Porter, 1980). However, these studies pay little attention to the impact of international institutional environments on firm performance. This study proposes that greater firm's institutional complexity is associated with greater learned knowledge and needs for information-processing. Thus, it may have positive and negative impacts on firm performance. On the other hand, TMT turnover and TMT size in this study are constructed as the capabilities of information-processing. Consequently, based on a strategic contingency perspective, this study expects that smaller TMT turnover or greater TMT size acts as a moderator to weaken the negative impact of institutional complexity on firm performance. Based on a sample with 301 U.S. firms and 1,404 observations, our results support most hypotheses proposed by this study. These findings once again document the importance of tailoring internal components with external environments (Prescott, 1986; Vissa \& Chacar, 2009). 
Table 4.5 Results of Fixed-effects Linear Regression Analyses for ROS

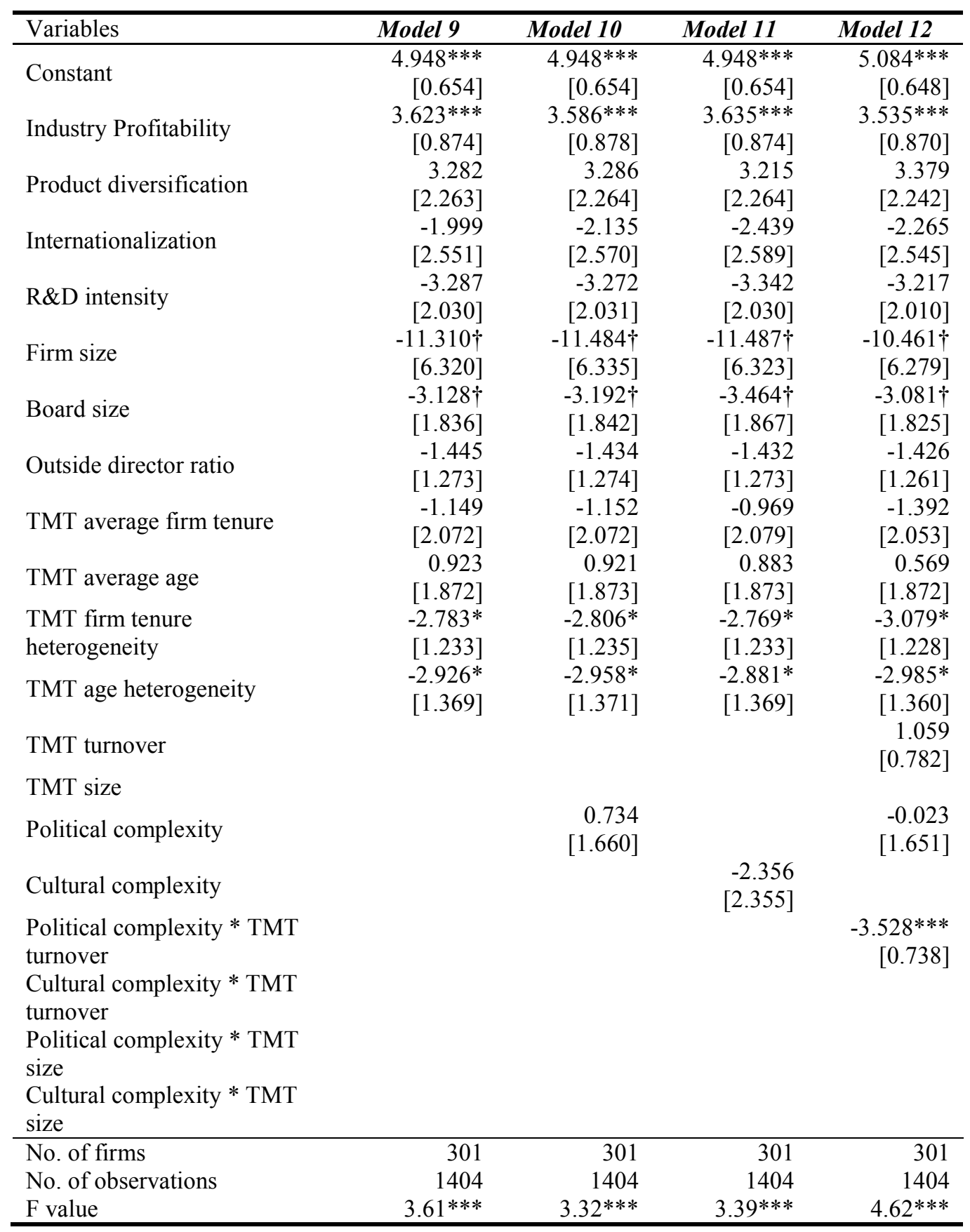


Table 4.5 Results of Fixed-effects Linear Regression Analyses for ROS (cont.)

\begin{tabular}{|c|c|c|c|c|}
\hline Variables & Model 13 & Model 14 & Model 15 & Model 16 \\
\hline \multirow{2}{*}{ Constant } & $4.914 * * *$ & $4.891 * * *$ & $4.830 * * *$ & $4.867 * * *$ \\
\hline & {$[0.652]$} & {$[0.648]$} & {$[0.648]$} & {$[0.625]$} \\
\hline \multirow{2}{*}{ Industry Profitability } & $3.603 * * *$ & $2.980 * *$ & $3.346^{* * *}$ & $2.618 * *$ \\
\hline & {$[0.871]$} & {$[0.879]$} & {$[0.871]$} & [0.849] \\
\hline \multirow{2}{*}{ Product diversification } & 3.302 & 3.334 & $3.719 \dagger$ & $4.045 \dagger$ \\
\hline & [2.257] & {$[2.242]$} & {$[2.244]$} & {$[2.163]$} \\
\hline \multirow{2}{*}{ Internationalization } & -2.482 & -2.517 & -2.313 & -3.136 \\
\hline & {$[2.580]$} & [2.546] & [2.564] & [2.492] \\
\hline \multirow{2}{*}{ R\&D intensity } & $-3.546 \dagger$ & -2.894 & -2.032 & -1.930 \\
\hline & {$[2.024]$} & {$[2.014]$} & [2.027] & [1.953] \\
\hline \multirow{2}{*}{ Firm size } & $-11.039 \dagger$ & $-11.721 \dagger$ & $-11.279 \dagger$ & -8.858 \\
\hline & [6.305] & {$[6.272]$} & {$[6.263]$} & [6.059] \\
\hline \multirow{2}{*}{ Board size } & $-3.666^{*}$ & -2.757 & -2.911 & -2.794 \\
\hline & {$[1.861]$} & [1.827] & [1.852] & [1.791] \\
\hline \multirow{2}{*}{ Outside director ratio } & -1.431 & -1.511 & -1.665 & -1.620 \\
\hline & {$[1.268]$} & {$[1.262]$} & {$[1.261]$} & [1.215] \\
\hline \multirow{2}{*}{ TMT average firm tenure } & -0.933 & -1.879 & -1.519 & -1.890 \\
\hline & {$[2.072]$} & {$[2.074]$} & {$[2.082]$} & {$[2.008]$} \\
\hline \multirow{2}{*}{ TMT average age } & 0.615 & 1.068 & 1.107 & 0.390 \\
\hline & {$[1.884]$} & {$[1.856]$} & {$[1.856]$} & {$[1.803]$} \\
\hline \multirow{2}{*}{ TMT firm tenure heterogeneity } & $-2.819 *$ & -1.928 & -1.763 & $-2.096 \dagger$ \\
\hline & {$[1.233]$} & {$[1.295]$} & [1.292] & {$[1.250]$} \\
\hline \multirow{2}{*}{ TMT age heterogeneity } & $-2.676 \dagger$ & -2.135 & $-2.607 \dagger$ & -1.730 \\
\hline & {$[1.370]$} & {$[1.377]$} & {$[1.374]$} & [1.330] \\
\hline \multirow{2}{*}{ TMT turnover } & 0.878 & & & $1.983 *$ \\
\hline & {$[0.788]$} & & & [0.814] \\
\hline \multirow{2}{*}{ TMT size } & & $-2.502 *$ & $-2.550 *$ & $-3.269 * *$ \\
\hline & & [1.012] & {$[1.010]$} & {$[1.051]$} \\
\hline \multirow{2}{*}{ Political complexity } & & 0.713 & & -0.440 \\
\hline & & {$[1.646]$} & & [1.595] \\
\hline \multirow{2}{*}{ Cultural complexity } & -2.727 & & -2.817 & $-4.541 *$ \\
\hline & {$[2.354]$} & & [2.336] & {$[2.265]$} \\
\hline \multirow{2}{*}{$\begin{array}{l}\text { Political complexity * TMT } \\
\text { turnover }\end{array}$} & & & & $-5.122 * * *$ \\
\hline & & & & {$[0.768]$} \\
\hline \multirow{2}{*}{$\begin{array}{l}\text { Cultural complexity } * \text { TMT } \\
\text { turnover }\end{array}$} & $-2.329 * *$ & & & $-3.593 * * *$ \\
\hline & {$[0.774]$} & & & {$[0.795]$} \\
\hline \multirow{2}{*}{$\begin{array}{l}\text { Political complexity * TMT } \\
\text { size }\end{array}$} & & $3.943 * * *$ & & $5.914 * * *$ \\
\hline & & [0.920] & & [0.963] \\
\hline \multirow{2}{*}{$\begin{array}{l}\text { Cultural complexity * TMT } \\
\text { size }\end{array}$} & & & $3.789 * * *$ & $4.549 * * *$ \\
\hline & & & {$[0.884]$} & [0.916] \\
\hline No. of firms & 301 & 301 & 301 & 301 \\
\hline No. of observations & 1404 & 1404 & 1404 & 1404 \\
\hline F value & $3.67 * * *$ & $4.66 * * *$ & $4.72 * * *$ & $8.50 * * *$ \\
\hline
\end{tabular}

Notes: 1. S.E. in square brackets. $2 .{ }^{* * *} \mathrm{p}<0.001 ; * * \mathrm{p}<0.01 ; * \mathrm{p}<0.05 ; \dagger \mathrm{p}<0.10 ; \mathrm{t}$ test are all twotailed tests. 
The directions for future research, at least, have the following three perspectives. First, employing a national setting, prior research has examined the effects of the interactions between environments and strategies (e.g., Prescott, 1986) or the interactions of environments and organizational structures (e.g., Covin \& Slevin, 1989) on performance. Future research may explore these interactions under international contexts. Second, this study constructs institutional environments as two dimensions: political and cultural. However, past research has proposed a variety of other national institutions, such as economic, financial, administrative, and knowledge-based (Berry, Guillen, \& Zhou, 2010). Thus, a direction of further research may examine the firm performance implication of the fit between institutional complexity constructed by these other dimensions and managerial IPCs. Third, this study only proposes TMT turnover and TMT size as two indicators to reflect the managerial IPCs. Future research may examine whether other managerial characteristics, such as heterogeneity of TMT characteristics, TMT education level, or TMT international experience, can reflect the managerial IPCs, and affect firm performance.

The practical implications have, at least, the following two perspectives. Managers should be aware that performance implications for institutional complexity are not isolated from managerial IPCs. In other words, for achieving superior firm performance, managers should take a firm's managerial IPCs into considerations, when they determine their spectrum of international markets or institutional diversity. Additionally, firms should simultaneously deploy or adjust their portfolio of top executives in order to handle complex circumstances caused by entering into more foreign markets and consequently facing more complexity of institutional environments. 
The main contributions of this study at least have the following three implications. First, it bridges the gap between international business theory and research on environments and TMTs. It does so by exploring in details the impacts of institutional complexity, TMT turnover, and TMT size on firm performance. It demonstrates that the importance of environments and the upper echelons are not only in national settings but also in international settings. Second, it echoes Verbeke et al's (2009) call by bringing the international environmental element, mainly institutional complexity, into the research of firm performance. This demonstrates that in addition to traditional international elements, such as foreign sales over total sales, foreign assets over total assets, and the number of foreign markets faced by firms (Geringer et al., 1989; Gomes \& Ramaswamy, 1999; Hitt et al., 1997), institutional complexity is another critical element for firms. Finally, this study contributes to offering a possible answer for inconsistent findings of the institutional complexity-firm performance association. Zahra et al. (2000) focus on the benefits of learning from various institutional environments, and suggest that institutional diversity is positively associated with firm performance. However, Goerzen and Beamish (2003) emphasize the drawbacks for managing institutional complexity. Indeed, operating in diversified institutions has its advantages and disadvantages. Offering a potential answer for inconsistent findings, this study proposes that managerial IPCs will determine the extent of benefits which the firm can extract from the diversified institutions an MNE faces. 


\section{REFERENCES}

Ahuja, G. \& Lampert, C. M. 2001. Entrepreneurship in the large corporation: A longitudinal study of how established firms create breakthrough inventions. Strategic Management Journal, 22(6-7): 521-543.

Amason, A. C. \& Sapienza, H. J. 1997. The effects of top management team size and interaction norms on cognitive and affective conflict. Journal of management, 23(4): 495-516.

Andrews, K. R. 1971. The Concept of Corporate Strategy. Homewood, IL: Irwin.

Bales, R. F. \& Borgatta, E. F. 1955. Size of group as a factor in the interaction profile. In A. P. Hare \& E. F. Borgatta \& R. F. Bales (Eds.), Small groups: Studies in social interaction: 495-512. Toronto: Random House.

Barkema, H. G. \& Drogendijk, R. 2007. Internationalising in small, incremental or larger steps? Journal of International Business Studies, 38(7): 1132-1148.

Barney, J. B. 1991. Firm resources and sustained competitive advantage. Journal of management, 17(1): 99-120.

Bartlett, C. A. \& Ghoshal, S. 1989. Managing across borders: the transnational solution. Boston, MA: Harvard Business School Press.

Becker, G. S. 1964. Human Capital. New York: NBER and Columbia University Press.

Berry, H., Guillen, M. F., \& Zhou, N. 2010. An institutional approach to cross-national distance. Journal of International Business Studies, 41(9): 1460-1480.

Birkinshaw, J., Toulan, O., \& Arnold, D. 2001. Global account management in multinational corporations: theory and evidence. Journal of International Business Studies, 32(2): 231-248.

Boddewyn, J. J. 1988. Political aspects of MNE theory. Journal of International Business Studies, 19(3): 341-363.

Bouquet, C., Morrison, A., \& Birkinshaw, J. 2009. International attention and multinational enterprise performance. Journal of International Business Studies, 40(1): 108-131.

Carpenter, M. A., Sanders, G., \& Gregersen, H. B. 2001. Bundling human capital with organizational context: The impact of international assignment experience on multinational firm performance and CEO pay. The Academy of Management Journal, 44(3): 493-511. 
Carpenter, M. A., Pollock, T. G., \& Leary, M. M. 2003. Testing a model of reasoned risk taking: governance, the experience of principals and agents, and global strategy in high technology IPO firms. Strategic Management Journal, 24(9): 803-820.

Certo, S. T., Lester, R. H., Dalton, C. M., \& Dalton, D. R. 2006. Top Management Teams, Strategy and Financial Performance: A Meta Analytic Examination. Journal of Management Studies, 43(4): 813-839.

Chacar, A. \& Vissa, B. 2005. Are emerging economies less efficient? Performance persistence and the impact of business group affiliation. Strategic Management Journal, 26(10): 933-946.

Chacar, A. S., Newburry, W., \& Vissa, B. 2010. Bringing Institutions into Performance Persistence Research: Exploring the Impact of the Product, Financial and Labor Market Institutions. Journal of International Business Studies, 41(7): 1119-1140.

Chatterjee, S. \& Wernerfelt, B. 1991. The link between resources and type of diversification: theory and evidence. Strategic Management Journal, 12(1): 33-48.

Child, J. 1972. Organizational structure, environment and performance: The role of strategic choice. Sociology, 6(1): 1-22.

Cohen, W. M. \& Levinthal, D. A. 1990. Absorptive capacity: a new perspective on learning and innovation. Administrative Science Quarterly, 35(1): 128-152.

Covin, J. G. \& Slevin, D. P. 1989. Strategic management of small firms in hostile and benign environments. Strategic Management Journal, 10(1): 75-87.

Cyert, R. M. \& March, J. G. 1963. A Behavioral Theory of the Firm. Englewood Cliffs, NJ: Prentice-Hall.

Dearborn, D. W. C. \& Simon, H. A. 1958. Selective perception: A note on the departmental identifications of executives. Sociometry, 21(2): 140-144.

Delios, A. \& Henisz, W. J. 2000. Japanese firms' investment strategies in emerging economies. The Academy of Management Journal, 43(3): 305-323.

Delios, A. \& Henisz, W. J. 2003. Political Hazards, Experience, and Sequential Entry Strategies: The International Expansion of Japanese Firms, 1980-1998. Strategic Management Journal, 24(11): 1153-1164.

Dess, G. G. \& Shaw, J. D. 2001. Voluntary turnover, social capital, and organizational performance. The Academy of Management Review, 26(3): 446-456. 
Dunning, J. H. 1997. Governments, globalization, and international business. Oxford and New York: Oxford University Press.

Dunning, J. H. \& Lundan, S. M. 2008. Multinational enterprises and the global economy. Cheltenham: Edward Elgar Publishing.

Egelhoff, W. G. 1991. Information-Processing Theory and the Multinational Enterprise. Journal of International Business Studies, 22(3): 341-368.

Galbraith, J. R. 1973. Designing complex organizations. Boston, MA: Addison-Wesley Longman Publishing Co., Inc.

Geringer, J. M., Beamish, P. W., \& DaCosta, R. C. 1989. Diversification strategy and internationalization: Implications for MNE performance. Strategic Management Journal, 24(13): 109-119.

Ghoshal, S. \& Nohria, N. 1989. Internal differentiation within multinational corporations. Strategic Management Journal, 10(4): 323-337.

Ghoshal, S., Korine, H., \& Szulanski, G. 1994. Interunit communication in multinational corporations. Management Science, 40(1): 96-110.

Goerzen, A. \& Beamish, P. W. 2003. Geographic scope and multinational enterprise performance. Strategic Management Journal, 24(13): 1289-1306.

Gomes, L. \& Ramaswamy, K. 1999. An Empirical Examination of the Form of the Relationship between Multinationality and Performance. Journal of International Business Studies, 30(1): 173-174.

Gordon, S. S., Stewart, W. H., Sweo, R., \& Luker, W. A. 2000. Convergence versus strategic reorientation: The antecedents of fast-paced organizational change. Journal of Management, 26(5): 911-945.

Grant, R. M. 1996. Toward a knowledge-based theory of the firm. Strategic Management Journal, 17(S): 109-122.

Haleblian, J. \& Finkelstein, S. 1993. Top management team size, CEO dominance, and firm performance: The moderating roles of environmental turbulence and discretion. The Academy of Management Journal, 36(4): 844-863.

Hambrick, D. C. \& Mason, P. A. 1984. Upper echelons: The organization as a reflection of its top managers. Academy of Management Review, 9(2): 193-206.

Hambrick, D. C. \& D'Aveni, R. A. 1992. Top team deterioration as part of the downward spiral of large corporate bankruptcies. Management Science, 38(10): 1445-1466. 
Hare, A. P. 1952. A study of interaction and consensus in different sized groups. American Sociological Review, 17(3): 261-267.

Harrigan, K. R. 1983. Research methodologies for contingency approaches to business strategy. The Academy of Management Review, 8(3): 398-405.

Harrison, E. F. 1975. The managerial decison-making process. Boston: Houghton Mifflin.

Henderson, A. D. \& Fredrickson, J. W. 1996. Information-processing demands as a determinant of CEO compensation. The Academy of Management Journal, 39(3): 575-606.

Henisz, W. J. 2000. The institutional environment for multinational investment. Journal of Law, Economics, and Organization, 16(2): 334-364.

Hill, G. W. 1982. Group versus individual performance: Are $n+1$ heads better than one? Psychological Bulletin, 91(3): 517-539.

Hitt, M. A., Hoskisson, R. E., \& Kim, H. 1997. International diversification: Effects on innovation and firm performance in product-diversified firms. Academy of Management Journal, 40(4): 767-798.

Hitt, M. A., Tihanyi, L., Miller, T., \& Connelly, B. 2006. International diversification: Antecedents, outcomes, and moderators. Journal of Management, 32(6): 831-867.

Hoffman, J. J., Lheureux, R. A., \& Lamont, B. T. 1997. The Effect of "Inner" and "Outer" TMT Size on The Performance of International Firms. Journal of Managerial Issues, 9: 121-134.

Hofstede, G. H. 1984. Culture's consequences: International differences in work-related values. Thousand Oaks, CA: Sage Publications, Inc.

House, R. J. 2004. Culture, leadership, and organizations: The GLOBE study of 62 societies. Thousand Oaks, CA: Sage Publications, Inc.

Huber, G. P. 1991. Organizational learning: The contributing processes and the literatures. Organization Science, 2(1): 88-115.

Hymer, S. H. 1976. The international operations of national firms: A study of direct foreign investment. Cambridge, MA: MIT press.

Jensen, M. C. \& Meckling, W. H. 1976. Theory of the firm: Managerial behavior, agency costs and ownership structure. Journal of financial economics, 3(4): 305-360. 
Johanson, J. \& Vahlne, J. E. 1977. The internationalization process of the firm-a model of knowledge development and increasing foreign market commitments. Journal of International Business Studies, 8(1): 23-32.

Johanson, J. \& Vahlne, J. E. 1990. The mechanism of internationalisation. International marketing review, 7(4): 11-24.

Karaevli, A. 2007. Performance consequences of new CEO Outsiderness: Moderating effects of pre and post succession contexts. Strategic Management Journal, 28(7): 681-706.

Katila, R. \& Ahuja, G. 2002. Something old, something new: A longitudinal study of search behavior and new product introduction. Academy of Management Journal, 45(6): 1183-1194.

Kogut, B. \& Singh, H. 1988. The effect of national culture on the choice of entry mode. Journal of International Business Studies, 19(3): 411-432.

Kostova, T. 1999. Transnational transfer of strategic organizational practices: A contextual perspective. Academy of Management Review, 24(2): 308-324.

Kostova, T. \& Zaheer, S. 1999. Organizational legitimacy under conditions of complexity: The case of the multinational enterprise. The Academy of Management Review, 24(1): 64-81.

Kostova, T. \& Roth, K. 2002. Adoption of an organizational practice by subsidiaries of multinational corporations: Institutional and relational effects. The Academy of Management Journal, 45(1): 215-233.

Kostova, T., Roth, K., \& Dacin, M. T. 2008. Note: Institutional Theory in the Study of Multinational Corporations: A Critique and new Directions. The Academy of Management Review, 33(4): 994-1006.

Lane, P. J., Salk, J. E., \& Lyles, M. A. 2001. Absorptive capacity, learning, and performance in international joint ventures. Strategic Management Journal, 22(12): 1139-1161.

Leana, C. R. \& Van Buren, H. J. 1999. Organizational social capital and employment practices. The Academy of Management Review, 24(3): 538-555.

Levitt, B. \& March, J. G. 1988. Organizational learning. Annual Review of Sociology, 14: 319-340. 
Lu, J. W. \& Beamish, P. W. 2004. International diversification and firm performance: The S-curve hypothesis. The Academy of Management Journal, 47(4): 598-609.

Madhavan, R. \& Prescott, J. E. 1995. Market value impact of joint ventures: The effect of industry information-processing load. The Academy of Management Journal, 38(3): $900-915$.

March, J. G. S. \& Simon, H. A. 1958. Organizations. New York: Wiley.

Meyer, K. E., Mudambi, R., \& Narula, R. 2011. Multinational enterprises and local contexts: the opportunities and challenges of multiple embeddedness. Journal of Management Studies, 48(2): 235-252.

Mohrman, S. A. \& Von Glinow, M. A. 1990. High technology organisations: context, organisation and people. Journal of Engineering and Technology Management, 6: 261-280.

Mudambi, R. \& Navarra, P. 2002. Institutions and international business: A theoretical overview. International Business Review, 11(6): 635-646.

North, D. C. 1990. Institutions, institutional change and economic performance. Cambridge: Cambridge university press.

Palepu, K. 1985. Diversification strategy, profit performance and the entropy measure. Strategic Management Journal, 6(3): 239-255.

Porter, M. E. 1985. Competitive advantage: creating and sustaining superior performance. New York: Free Press.

Prescott, J. E. 1986. Environments as moderators of the relationship between strategy and performance. The Academy of Management Journal, 29(2): 329-346.

Sanders, W. M. G. \& Carpenter, M. A. 1998. Internationalization and firm governance: The roles of CEO compensation, top team composition, and board structure. The Academy of Management Journal, 41(2): 158-178.

Schwens, C., Eiche, J., \& Kabst, R. 2011. The moderating impact of informal institutional distance and formal institutional risk on SME entry mode choice. Journal of Management Studies, 48(2): 330-351.

Scott, W. R. 1995. Institutions and organizations. Thousand Oaks, CA: Sage Publications, Inc.

Shaw, M. E. 1981. Group dynamics: The psychology of small group behavior. New York: McGraw-Hill. 
Simons, T., Pelled, L. H., \& Smith, K. A. 1999. Making use of difference: Diversity, debate, and decision comprehensiveness in top management teams. The Academy of Management Journal, 42(6): 662-673.

Srivastava, A. \& Lee, H. 2005. Predicting order and timing of new product moves: the role of top management in corporate entrepreneurship. Journal of Business Venturing, 20(4): 459-481.

Tallman, S. \& Li, J. 1996. Effects of international diversity and product diversity on the performance of multinational firms. Academy of Management Journal, 39(1): 179196.

Teece, D. J., Pisano, G., \& Shuen, A. 1997. Dynamic Capabilities and Strategic Management. Strategic Management Journal, 18(7): 509-533.

Tushman, M. L. \& Rosenkopf, L. 1996. Executive succession, strategic reorientation and performance growth: A longitudinal study in the US cement industry. Management Science, 42(7): 939-953.

Venkatraman, N. 1989. The concept of fit in strategy research: Toward verbal and statistical correspondence. The Academy of Management Review, 14(3): 423-444.

Verbeke, A., Li, L., \& Goerzen, A. 2009. Toward More Effective Research on the Multinationality-Performance Relationship. Management International Review, 49(2): 149-161.

Virany, B., Tushman, M. L., \& Romanelli, E. 1992. Executive succession and organization outcomes in turbulent environments: An organization learning approach. Organization Science, 3(1): 72-91.

Vissa, B. \& Chacar, A. S. 2009. Leveraging ties: the contingent value of entrepreneurial teams' external advice networks on Indian software venture performance. Strategic Management Journal, 30(11): 1179-1191.

Von Glinow, M. A., Shapiro, D. L., \& Brett, J. M. 2004. Can we talk, and should we? Managing emotional conflict in multicultural teams. The Academy of Management Review, 29(4): 578-592.

Westney, D. E. 1993. Institutionalization theory and the multinational corporation. In D. E. Westney (Ed.), Organization theory and the multinational corporation: 53-76. New York: St Martin's Press.

Wiersema, M. F. \& Bantel, K. A. 1992. Top management team demography and corporate strategic change. The Academy of Management Journal, 35(1): 91-121. 
Wiersema, M. F. \& Bantel, K. A. 1993. Top management team turnover as an adaptation mechanism: The role of the environment. Strategic Management Journal, 14(7): 485-504.

Williamson, O. E. 1975. Markets and hierarchies, analysis and antitrust implications. New York: Free Press.

Zaheer, S. 1995. Overcoming the liability of foreignness. The Academy of Management Journal, 38(2): 341-363.

Zahra, S. A., Ireland, R. D., \& Hitt, M. A. 2000. International expansion by new venture firms: International diversity, mode of market entry, technological learning, and performance. The Academy of Management Journal, 43(5): 925-950.

Zahra, S. A. \& George, G. 2002. Absorptive capacity: A review, reconceptualization, and extension. The Academy of Management Review, 27(2): 185-203.

Zollo, M. \& Winter, S. G. 2002. Deliberate learning and the evolution of dynamic capabilities. Organization Science, 13(3): 339-351. 


\section{YU-KAI WANGg}

January $13^{\text {th }}, 1971$

1991-1994

1994-1996

1996-1998

1998-2006

2007-2011
Born, Changhua, Taiwan (R.O.C.)

B.B.A., International Trade

Feng Chia University

Taichung, Taiwan (R.O.C.)

M.B.A.

National Taipei University

Taipei, Taiwan (R.O.C.)

Financial and Budget Officer Compulsory Military Service 204 Factor, Ministry of Defense I-Lan, Taiwan (R.O.C.)

Technician, Specialist, and Section Member Ministry of Economic Affairs Taipei, Taiwan (R.O.C.)

Doctoral Candidate in Business Administration Florida International University Miami, Florida

\section{PUBLICATIONS AND PRESENTATIONS}

Wang, Y.-K. \& Chung, C.C. Economic and Social Drivers for Strategic Alliances. Paper presented at Academy of Management Annual Meeting, 2011, San Antonio, U.S.

Wang, Y.-K. \& Yang, K. The Impact of International Diversification on CEO Turnover. Paper presented at Academy of International Business Annual Meeting, 2011, Nagoya, Japan.

Wang, Y.-K. The Drives of MNEs' Foreign Entrepreneurial Activities: An Agency Perspective. Paper presented at the Reading IB Conference, 2011, Reading, U.K.

Wang, Y.-K. MNE's Institutional Complexity and Top Executive Compensation. Paper presented at the 2010 Strategic Management Society Conference, 2010, Rome, Italy. 
Chacar, A. \& Wang, Y.-K. Are Top Executives Paid for Managing MNE's Institutional Complexity? Paper presented at Academy of Management Annual Meeting, 2010, Montreal, Canada.

Wang, Y.-K. \& Chung, C.C. The Effects of Strategic Needs and Social Networks on Alliance Formation. Paper presented at Academy of Management Annual Meeting, 2010, Montreal, Canada.

Wang, Y.-K. \& Chacar, A. The Effects of Managing MNE's Institutional Complexity on Top Executives Compensation. Paper presented at Academy of International Business Annual Meeting, 2010, Rio de Janeiro, Brazil.

Wang, Y.-K. International Strategic Alliance Formations of International New Ventures: A Signaling Theory Perspective. Paper presented at Academy of International Business Annual Meeting, 2010, Rio de Janeiro, Brazil.

Wang, Y.-K. Integrating Managerial Information Processing Capabilities into the Transaction Cost Model of Entry Mode Choice. Paper presented at Academy of International Business Conference, 2009, San Diego, U.S.

Wang, Y.-K. The Effects of Industry Structure and Boards of Directors on the Alliance Formation of New Ventures. Paper presented at International Western Academy of Management Conference, 2008, Taipei, Taiwan.

Wang, Y.-K. The Link between a Firm's Strategic Decision for Change on its Workforce and Organizational Performance under Different Human Capital Considerations. Paper presented at Southern Management Association Annual Conference, 2007, Nashville, U.S. 